\title{
Association of herpes virus infections and arterial disease
}

Citation for published version (APA):

Plagis-Span, A. H. M. (1991). Association of herpes virus infections and arterial disease. [Doctoral Thesis, Maastricht University]. Rijksuniversiteit Limburg. https://doi.org/10.26481/dis.19910913ap

Document status and date:

Published: 01/01/1991

DOI:

10.26481/dis.19910913ap

Document Version:

Publisher's PDF, also known as Version of record

\section{Please check the document version of this publication:}

- A submitted manuscript is the version of the article upon submission and before peer-review. There can be important differences between the submitted version and the official published version of record.

People interested in the research are advised to contact the author for the final version of the publication, or visit the DOI to the publisher's website.

- The final author version and the galley proof are versions of the publication after peer review.

- The final published version features the final layout of the paper including the volume, issue and page numbers.

Link to publication

\footnotetext{
General rights rights.

- You may freely distribute the URL identifying the publication in the public portal. please follow below link for the End User Agreement:

www.umlib.nl/taverne-license

Take down policy

If you believe that this document breaches copyright please contact us at:

repository@maastrichtuniversity.nl

providing details and we will investigate your claim.
}

Copyright and moral rights for the publications made accessible in the public portal are retained by the authors and/or other copyright owners and it is a condition of accessing publications that users recognise and abide by the legal requirements associated with these

- Users may download and print one copy of any publication from the public portal for the purpose of private study or research.

- You may not further distribute the material or use it for any profit-making activity or commercial gain

If the publication is distributed under the terms of Article $25 \mathrm{fa}$ of the Dutch Copyright Act, indicated by the "Taverne" license above, 
ASSOCIATION OF HERPES VIRUS INFECTIONS AND ARTERIAL DISEASE 



\title{
ASSOCIATION OF HERPES VIRUS INFECTIONS AND ARTERIAL DISEASE
}

\section{PROEFSCHRIFT}

\author{
ter verkrijging van de graad van doctor \\ aan de Rijksuniversiteit Limburg te Maastricht, \\ op gezag van de Rector Magnificus, prof. Mr. M.J. Cohen, \\ volgens het besluit van het College van Dekanen, \\ in het openbaar te verdedigen op \\ vrijdag, 13 september 1991 om 16.00 uur
}

door 
PROMOTOR:

Prof.dr. C.P.A. van Boven

CO-PROMOTOR:

Mw. dr. C.A. Bruggeman

BEOORDELINGSCOMMISSIE:

Prof.dr. F.C.S. Ramaekers, voorzitter

Prof.dr. F.T. Bosman

Prof.dr. J. Drukker

Prof.dr, R. van Furth

Prof.dr. R.F.A. Zwaal 
Aan Jason, Misha en mijn ouders 



\section{CONTENTS}

Chapter 1

Introduction. Aims of the study

1.1

Introduction

Chapter 2

Chapter 3

3.1

3.2

3.2 .1

3.2 .2

3.2 .3

3.2 .4

3.2 .5

3.2 .6

3.3

3.3.1

3.3.2

3.3 .3

3.4

3.5

3.6

Chapter 4

4.1

4.2

Role of herpesvirus in vascular injury: literature overview

Experimentally induced atherosclerosis by hypercholesterolemia 24

Viruses and atherosclerosis

Experimentally induced atherosclerosis by herpesvirus infection: animal models

$\begin{array}{ll}\text { Association of herpesviridae with atherosclerosis in humans } & 27\end{array}$

In vitro studies: herpesvirus infection of endothelial cells 28

Endothelial cell-leukocyte interaction $\quad 29$

Leukocyte dependent adherence $\quad 29$

Endothelial cell mechanisms $\quad 30$

Endothelial cell-derived or leukocyte-derived soluble mediators which induce leukocyte adherence

CMV induces vascular injury in the rat: a model for the study of early atherosclerotic lesions

Introduction

Materials and methods $\quad 47$

Rats $\quad 47$

$\begin{array}{ll}\text { Virus stock } & 48\end{array}$

Experimental groups $\quad 48$

Blood lipid studies $\quad 49$

Light microscopy $\quad 49$

$\begin{array}{ll}\text { Statistical analysis } & 50\end{array}$

Results 51

Weight $\quad 51$

Plasma lipids $\quad 51$

Light microscopy $\quad 51$

$\begin{array}{ll}\text { Discussion } & 58\end{array}$

Acknowledgements $\quad 60$

$\begin{array}{ll}\text { References } & 60\end{array}$

CMV induced vascular injury: an electron-microscopic study in the rat 
$\begin{array}{lll}4.2 .1 & \text { Virus stock } & 66\end{array}$

4.2.2 Rats 66

4.2.3 Design of the experiment 66

4.2.4 Electron microscopy 66

$\begin{array}{lll}4.3 & \text { Results } & 67\end{array}$

$\begin{array}{lll}4.3 .1 & \text { SEM } & 67\end{array}$

$\begin{array}{lll}4.3 .2 & \text { TEM } & 69\end{array}$

$\begin{array}{lll}4.4 & \text { Discussion } & 72\end{array}$

4.5 Acknowledgements $\quad 74$

$\begin{array}{lll}4.6 & \text { References } & 74\end{array}$

Chapter 5 Virus induced monocytes adherence to endothelial cells in $\begin{array}{ll}\text { culture } & 77\end{array}$

$\begin{array}{lll}5.1 & \text { Introduction } & 79\end{array}$

$5.2 \quad$ Materials and methods $\quad 80$

$\begin{array}{lll}5.2 .1 & \text { Cell cultures } & 80\end{array}$

$\begin{array}{lll}5.2 .2 & \text { Virus } & 80\end{array}$

5.2.3 Infection of the endothelial cells 80

5.2.4 Evaluation of the HSV-1 infection in HUVEC 81

$\begin{array}{lll}5.2 .5 & \text { Isolation of monocytes } & 81\end{array}$

$\begin{array}{lll}5.2 .6 & \text { Adherence assay } & 82\end{array}$

$\begin{array}{lll}5.2 .7 & \text { Statistics } & 83\end{array}$

$\begin{array}{lll}5.3 \quad \text { Results } & 83\end{array}$

5.3.1 HSV-1 infection of HUVEC 83

5.3.2 Effect of HSV-1 infection on the adherence of monocytes 83

5.3.3 Effect of supernatant of HSV-1-infected cells on the
adherence of MC to HUVEC

5.3.4 Effect of tunicamycin on the virus induced enhancement of the MC-adherence $\quad 86$

$\begin{array}{lll}5.4 & \text { Discussion } & 87\end{array}$

$5.5 \quad$ Acknowledgements $\quad 88$

5.6 References 88

Chapter 6 The effect of cytomegalovirus infection on the adherence

6.1 Introduction 93

$6.2 \quad$ Materials and methods 93

6.2.1 Cell cultures 93

6.2.2 Virus 94

6.2.3 Viral inoculation of the cell monolayer 94

6.2.4 Treatment of endothelial cells with tunicamycin 94

6.2.5 Evaluation of the CMV infection in HUVEC 95

6.2.6 Isolation of polymorphonuclear leukocytes (PMN) 95

6.2.7 Adherence assay 96

6.2.8 Statistics 96

$6.3 \quad$ Results 97

6.3.1 CMV infection of HUVEC 97

6.3.2 Effect of CMV infection on the adherence of PMNs 98 
6.3.3 The effect of supernatant of CMV infected cells on the adherence of PMNs to HUVEC

6.3.4 Effect of tunicamycin on the virus induced enhancement of the PMN adherence

6.4 Discussion

101

6.5 Acknowledgements

103

6.6 References

Chapter 7

7.1

7.2

7.2 .1

7.2 .2

7.2 .3

7.2 .4

7.2 .5

7.2 .6

7.2 .7

7.2 .8

7.2 .9

7.2.10

7.3

7.3.1

\section{3 .2}

7.3 .3

7.4

7.5

7.6

Chapter 8

8.1

8.2

8.2.1

8.2 .2

8.2 .3

8.2.4

8.2 .6

The effect of virus infection on the adherence of leukocytes or platelets to endothelial cells

Introduction

Materials and methods

Reagents

108

Cell cultures

108

Virus

108

Viral inoculation of the monolayer

108

Isolation of monocytes and polymorphonuclear leukocytes

Isolation of platelets

Measurement of MC and PMN adherence

Measurement of platelet adherence

Treatment of endothelial cells with tunicamycin

Statistics

Results

Effect of HSV-1 or CMV infection on the MC and PMN adherence

The effect of supernatant of virus infected cells on the adherence of MC and PMN to endothelial cells

The effect of tunicamycin on the virus induced PMN or $\mathrm{MC}$ adherence

Effect of HSV-1 and CMV infection on the adherence of platelets

Discussion

Acknowledgements

References

Cytomegalovirus induced PMN adherence in relation to an ELAM-1 antigen present on infected endothelial cell monolayers

Cells

Viral techniques

Induction and detection of an activation antigen ELAM-1

in CMV infected endothelial cell monolayers 
$\begin{array}{lll}\text { 8.2.7 Adhesion assay } & 126\end{array}$

$\begin{array}{lll}8.2 .8 & \text { Statistical analysis } & 127\end{array}$

8.3 Results 127

8.3.1 ELAM-1 and viral antigen expression 127

8.3.2 Il-1 production and effect of anti-IL-1 128

$\begin{array}{ll}\text { 8.3.3 Adhesion experiments } & 129\end{array}$

8.3.4 PMN adhesion through the CD18 receptor 130

8.4 Discussion 131

8.5 Acknowledgements 132

8.6 References 132

$\begin{array}{lll}\text { Chapter } 9 & \text { Summary and conclusions } & 135\end{array}$

$9.1 \quad$ Introduction 137

$9.2 \quad$ Relation virusinfection and atherosclerosis in vivo? 137

$9.3 \quad$ In vitro studies 138

9.4 Conclusion and hypothesis 141

9.5 References 141

$\begin{array}{lr}\text { Samenvatting } & 144\end{array}$

$\begin{array}{ll}\text { Dankwoord } & 147\end{array}$

$\begin{array}{lr}\text { Curriculum vitea } & 149\end{array}$ 


CHAPTER I

INTRODUCTION.

AIMS OF THE THESIS. 



\subsection{INTRODUCTION}

Atherosclerosis is the principle cause of most cardiovascular diseases (1). The pathogenesis of atherosclerotic vascular disease involves a variety of complex interactions of on one side cellular and humoral constituents of blood and on the other side of components of the vessel wall. The atherosclerotic lesion is considered to be the result of a series of events including endothelial injury, leukocyte and platelet interaction with the arterial wall, the appearance of intimal monocytes/macrophages and intimal T-cells, medial smooth muscle cell migration into the intima followed by SMC-proliferation, and lipid accumulation (2).

Many investigators have suggested that "endothelial activation" is an important first event that eventually culminates in the development of an atherosclerotic lesion (2). Based on these ideas Ross formulated the "response to injury" hypothesis. This hypothesis proposes that "injury" of the endothelium is the initial insult which leads to the formation of an advanced atherosclerotic lesion (3). The key event in this process is the intimal smooth muscle cell proliferation $(2,3)$.

In general the following pathway for smooth muscle cell-accumulation is suggested (3).

Endothelial activation results in the production of growth factors (endothelial cellderived growth factor [EDGF]) which among others stimulates the migration of smooth muscle cells from the media into the intima. This is accompanied by activation of the smooth muscle cells, endogenous production of growth factors by smooth muscle cells, and increased activation of endothelium. In addition, attached monocytes which migrate to the subendothelium are capable of forming and secreting mitogens (macrophage-derived growth factor [MDGF]). In some cases of advanced atherosclerotic lesions, when areas of endothelium are depleted of cells, platelet attachment occurs, that also leads to the release a growth factor (platelet-derived growth factor [PDGF]) (3).

The hypothesis suggests that if such endothelial injury continues over a prolonged period, as may be the case at particular anatomic sites such as branches and bifurcations in the arterial tree, then the above described interactions could lead to the development of the fibrous plaque, i.e. the advanced lesion of atherosclerosis (3).

Neither the primary causes nor the sequence of events leading to arterial injury are fully clear. In this context speculations were made that viral infections could initiate atherogenesis (4-7). This viral link was substantiated by the discovery that an avian herpesvirus could cause atherosclerotic lesions in chickens similar to lesions found in humans (8-13). Furthermore, it was demonstrated that this avian herpesvirus induced lipid accumulation in cultured vascular smooth muscle cells (14) and altered the aortic cholesterol metabolism (15). These findings encouraged investigators to study the possibility of an association between atherosclerosis and infection with human herpesviruses.

Several studies indeed seem to confirm this association. Melnick et al. $(16,17)$ reported that human CMV-antigens (16) and CMV nucleic acid sequences (17) were present in smooth muscle cells cultured from arterial tissue surgically removed from patients with severe arterial disease. In a later report it was shown in similar specimens by electronmicroscopy that herpesvirus-like particles were present in the endothelial and smooth muscle cells of the proximal aorta (18). Benditt et al. (19) detected also nucleic acid sequences of herpes simplex virus in specimens of aortic tissue removed from patients 
during coronary-artery-bypass surgery. Seroepidemiological studies, comparing patients requiring vascular surgery for atherosclerosis and a control group, showed that a higher level of CMV-antibodies was present in the patients than in the control group (30). Yamashiroya et al. (21) demonstrated that HSV and CMV genomic sequences, and antigens, were present in coronary arteries and thoracic aortas derived from young trauma victims; predominantly in areas of the arterial wall showing early atheromatous changes, namely, focal areas of intimal thickening with smooth muscle cell proliferation and lymphocytic infiltration.

Studies performed in our laboratory $(22,23)$ demonstrated, by the more sensitive polymerase chain reaction, CMV-DNA in $90 \%$ of arterial tissues of patients undergoing vascular surgery as compared to $53 \%$ of the autopsy-control group (23).

Femoral or abdominal arterial samples derived from patients undergoing vascular surgery and from an autopsy-control group who died of non-atherosclerosis-associated diseases were used in this study. As in studies performed by other investigators $(16,18,19,21)$ no infectious virus could be isolated from the arterial specimens.

Supporting evidence that herpesvirus infection, in particular CMV, may play a role in atherosclerosis was found in patients undergoing heart-transplantation. In these studies, a large number of patients who had received heart transplants, were followed for CMV infection and the development of late graft atherogenesis in the transplanted organs. In patients with CMV-infection an accelerated arteriosclerosis occurred in the vessels of the transplanted heart (24-26) as well as a more frequent development of atherosclerosis (25).

Hruban et al. (27) reported the identification of CMV nucleic acids in the coronary arteries of three heart transplant recipients with severe transplant-related accelerated arteriosclerosis, but not in two patients who died of other causes. Although focal endothelial cell positivity was identified, the strongest hybridization signal was found in cells morphologically consistent with smooth muscle cells (27).

In conclusion, clinical and experimental studies provides evidence that virus is present in the vessel wall. It seems likely that the virus is present in a latent stage: viral DNA was found in cells of vascular tissue that showed minimal atherosclerotic changes, but infectious virus could not be isolated $(16,19,21,23)$.

As mentioned above the initial event resulting in smooth muscle cell proliferation is probably an injury of the endothelial lining of the vessel wall. Several in vitro studies demonstrated that members of the herpesvirus family can infect endothelial cells (28-33). The viral infection of endothelium resulted in an increased adherence of polymorphonuclear leukocytes (34-36). This inflammatory type of response set off by a viral infection is proposed to be one of the initiating events in atherogenesis, which leads to the aim of this study.

\subsection{AIMS OF THE THESIS}

The aims of the studies described in this thesis were firstly to investigate in vivo, in a rat model, if a CMV infection is able to induce early vascular lesions comparable to the lesions described by others in rats with a hypercholesterolemia.

Secondly, in vitro studies, employing cultures of human umbilical vein endothelial cells, were performed to study whether infection with herpes simplex virus type 1 (HSV-1) or 
cytomegalovirus (CMV) infection causes an endothelial cell alteration resulting in an enhanced interaction between leukocytes and endothelial cells, and to gain a further insight in the mechanism(s) involved in the viral induced endothelial-leukocyte interaction.

\subsection{OUTLINE OF THE STUDY}

In the in vivo studies the effect of an acute viral infection of endothelium was examined, with special consideration to early vascular events including endothelial cell alterations, endothelial-leukocyte interaction, and alterations in the subendothelium. For this purpose rats were infected with a rat-CMV. In chapter III, plasma lipid changes, the adhesion of leukocytes to the endothelium and lipid alterations in the endothelium observed by light microscopy are described, while in chapter IV the ultrastructural changes in the vessel wall, especially those of the endothelium and subendothelium induced after CMV infection are described.

In the in vitro studies the effect of an acute virus infection on the endothelial cells was investigated, with special attention to the interaction between leukocytes and endothelium.

In chapter $\mathrm{V}$ the development of an in vitro method to measure monocyte adhesion to virus infected endothelium is described. For this purpose herpes simplex virus type-1 (HSV-1) infected human umbilical vein endothelial cells were used. To gain optimal adhesion conditions, the variabilities in the infection dose and in the amount of monocytes were investigated. Because most of the surface adhesion molecules are glycoproteins we examined whether the monocyte adhesion to virus infected endothelium takes place via a glycoprotein-synthesis dependent mechanism.

In chapter VI the effects of cytomegalovirus (CMV) infection of endothelial cells are reported, in particular the adhesion of polymorphonuclear leukocytes (PMN) to CMV infected endothelial cell layers. Chapter VII monocyte-, polymorphonuclear leukocyte-, and platelet-adhesion to endothelial cell layers infected with HSV-1 or CMV under optimal assay-circumstances is described.

In chapter VIII the mechanism and pattern of CMV-induced PMN adhesion are studied in more detail. Activation of virus-infected endothelial cells was demonstrated by using a monoclonal antibody against an activation antigen, ELAM-1, and the involvement of ELAM-1 in virus-induced adherence was studied. In addition, the production of interleukin-1 and its role in adhesion was investigated.

In the final chapter IX the possible role of herpesviruses in the atherosclerotic process and a working hypothesis of the steps involved are discussed.

\subsection{REFERENCES}

1. Report of the Working Group of Arteriosclerosis of the National Heart,Lung, and Blood Institute, vol.2, Government Printing Office, Washington DC, 1981

2. Ip JH, Fuster V, Badimon L, Badimon J, Taubman MB, Chesebro JH: Syndromes of accelerated atherosclerosis: Role of vascular injury and smooth muscle cell proliferation. J Am Coll Cardiol 15: $1667,1990$.

3. Ross R: The pathogenesis of atherosclerosis-an update. N Engl J Med 314: 488, 1986 
4. Burch GE, Tsui CY, Harb JM: Pathologic changes of aorta and coronary arteries of mice infected with coxsackie $B_{4}$ virus (35641). Proc Soc Exp biol med 137: 657, 1971.

5. Burch GE, Harb JM, Hiramoto Y, Shewey L: Viral infection of the aorta of man associated with early atherosclerotic changes. Am Heart J 86: 523, 1973.

6. Burch GE: Viruses and atherosclerosis. Am Heart J 87: 407, 1974.

7. Smith KO, Gehle WD, Sanford BA: Evidence for chronic viral infections in human arteries. Proc Soc Exp Biol Med 147: 357, 1974.

8. Fabricant CG, Krook L, Gillespie JH: Virus-induced cholesterol crystals. Science 181: 566, 1973.

9. Fabricant CG, Fabricant J, Litrenta MM, Minick CR: Virus-induced-atherosclerosis. J Exp Med 148: $335,1978$.

10. Minick CR, Fabricant CG, Fabricant J, Litrenta MM: Atheroarteriosclerosis induced by infection with a herpesvirus. Am J Pathol 96: 673, 1979.

11. Fabricant CG, Fabricant J, Minick CR, Litrenta MM: Herpesvirus induced atherosclerosis. In: Viruses in naturally occuring cancers. Cold Spring Harbor Conferences on cell proliferation, vol 7 , book B. Essex M, Todaro G, zür Hausen, eds Cold Spring Harbor Laboratory, pp 1251, 1980.

12. Fabricant CG: Herpesvirus-induced atherosclerosis. Diabetes 30 (suppl.2): 29, 1981.

13. Fabricant CG, Fabricant J, Minick CR, Litrenta MM: Herpesvirus-induced atherosclerosis in chickens. Fed Proc 42: 2476, 1983.

14. Fabricant CG, Hajiar DP, Minick CR: Lipid accumulations in cultured vascular smooth muscle cells infected with Marck's disease herpesvirus. Fed Proc 39: 1110, 1980.

15. Haijar DP, Fabricant CG, Minick CR, Fabricant J. Virus-induced atherosclerosis - herpesvinus infection alters aortic cholesterol metabolism and accumulation. An J Pathol 122: 62, 1986.

16. Melnick JL, Petrie BL, Dreesman GR, McCollum CH, Burck J, DeBakey ME. Cytomegalovirus antigen within human arterial smooth muscle cells. Lancet 2: 644, 1983.

17. Petrie BL, Melnick JL, Adam E, Burek J, McCollum CH, DeBakey ME. Nucleic acid sequences of cytomegalovirus in cells cultured from human arterial tissue. J Infect Dis 155: 158, 1987.

18. Gyorkey F, Melnick JL, Guinn GA, Gyorkey P, DeBakey ME: Herpesviridae in the endothelial and smooth muscle cells of the proximal aorta in arteriosclerotic patients. Exp Mol Pathol 40: 328, 1984.

19. Benditt EP, Barrett T, McDougall JK. Viruses in the etiology of atherosclerosis. Proc Natl Acad Sci USA 80: 6386, 1983.

20. Adam E, Probtsfield JL, Burek J, McCollum CH, Melnick JL, Petrie BL, Dailey KR, DeBackey ME: High levels of cytomegalovirus antibody in patient requiring vascular surgery for atherosclerosis. Lancet 8554: $291,1987$.

21. Yamashiroya HM, Ghosh L, Yang R, Robertson AL Jr: Herpesviridae in the coronary arteries and aorta of young trauma victims. Am J Pathol 130: 71, 1988.

22. Hendrix MGR, Dormans PHJ, Kitslaar P, Bosman F, Bruggeman CA: The presence of cytomegalovirus nucleic acids in arterial walls of atherosclerotic and nonatherosclerotic patients. Am J Pathol 134: 1151, 1989.

23. Hendrix MGR, Salimans MMM, van Boven CPA, Bruggeman CA: High prevalence of latently present cytomegalovirus in arterial walls of patients suffering from grade III atherosclerosis. Am J Pathol 136: 23, 1990.

24. Wreghitt TG, Hakim M, Gray JJ, Kucia S, Cory-Pearce R, Wallwork J, English TAH: A detailed study of cytomegalovinus infections in the first 160 heart and heart/hung transplant recipients at Papworth Hospital, Cambridge, England. Transplant Proc 19: 2495, 1987

25. Grattan MT, Moreno-Cabral CE, Starnes VA, Oyer PE, Stinson EB, Shumway NE: Cytomagalovirus infection is associated with cardiac allograft rejection and atherosclerosis. JAMA 261:3561, 1989.

26. McDonald K, Rector TS, Braunlin EA, Kubo SH, Olivari MT: Association of coronary artery disease in cardiac transplant recipients with cytomegalovirus infection. An J Pathol 64: 359, 1989.

27. Hruban RH, Wu T-C, Beschorner WE, Cameron DE, Ambinder RF, Baumgartner WA, Reitz BA, Hutchins GM: Cytomegalovirus nucleic acids in allografted hearts. Human pathol 21: 981, 1990.

28. Friedman HM, Macarak EJ, MacGregor RR, Wolfe J, Kefalides NA: Virus infection of endothelial cells. J Infect Dis 143: 266, 1981. 
29. Gönczöl E, Boldogh I, Vaczi L: IgG-Fc-binding receptors in cells abortively infected, or transformed, by human cytomegalovirus. Acta Microbiol Acad Sci Hung 28: 157, 1981.

30. Friedman HM, Cohen GH, Eisenberg RJ, Seidel $C A$, Cines DB: Glycoprotein $C$ of herpes simplex virus acts as a receptor for the $\mathrm{C} 3 \mathrm{~b}$ complement component on infected cells. Nature 309: 633, 1984.

31. Bruggeman CA, Debie WHM, Muller AD, Schutte B, van Dam-Mieras: Cytomegalovirus alters the von Willebrand factor content in human endothelial cells. Thromb Haemostasis 59: 264, 1988.

32. Smiley ML, Mar E-C, Huang E-S: Cytomegalovirus infection and viral-induced transformation of human endothelial cells. J Med Virol 25: 213, 1988.

33. Waldman WJ, Sheddon JM, Stephens RE, Roberts WH: Enhanced endothelial cytopathogenecity induced by a cytomegalovirus strain propagated in endothelial cells. J Med Virol 28: 223, 1989.

34. MacGregor RR, Friedman HM, Macarek EJ, Kefalides NA. Virus infection of endothelial cells increases granulocyte adherence. J Clin Invest 65: 1469, 1980.

35. Zajac BA, ONeill K, Friedman HM, MacGregor RR: Increased adherence of human granulocytes to herpes simplex virus type 1 infected endothelial cells. In vitro Cell Devel Biol 24: 321, 1988.

36. Visser MR, Jacob HS, Goodman JL, McCarthy JB, Furcht LT, Vercellotti GM. Granulocyte-mediated injury to herpes simplex virus-infected human endothelium. Lab Invest 60:296, 1989. 

CHAPTER II

ROLE OF HERPESVIRUS IN VASCULAR INJURY. LITERATURE REVIEW 



\subsection{ATIIEROSCIEROSIS}

Atherosclerosis is the most common discase that afflicts Western society. It is the underlying cause of most cardiovascular diseases, including myocardial infarctions and cerebrovascular insufficiency $(1,2)$. A varicty of complex interaction among cellular and humoral constituents of blood and components of the vessel wall are involved in the pathogenesis of atherosclerotic vascular disease (1). The principal cellular participants in this interactive process include endothelial cells, monocyte/macrophages, blood platelets, and vascular smooth muscle cells. Recently it was shown by the application of monoclonal antibody technology, that T-lymphocytes are present in regions of human atheromata and possibly involved in the atherosclerotic process (3-8).

It should be emphasized that the complicated lesion found in adult human arteries is not the result of a single factor but of a constellation of etiological factors. Atherosclerosis may thus be defined as an abnormal response of some areas of the vascular wall to the cumulative and often synergistic effects of episodic injury-repair processes, causing permanent arterial damage (9). The atherosclcrotic plaques, particular those seen in advanced atheroscloresis in humans, are characterized by an increased number of intimal smooth muscle cells. The findings of Clowes et al. who observed in an injured artery, replication of smooth muscle cells $(10,11)$ indicate that the smooth muscle proliferation is a key event in the development of atherosclerotic lesions $(2,12-17)$. However, it is belicved that "injury" to the endothelium is the initiating event that could result in the development of atherosclerosis $(12-15,18-20)$.

\subsection{ENDO'THELIAL INJURY}

In 1976, "endothelial injury" and the cellular response-to-injury were formulated by Ross and Glomset (18). In 1986 Ross reformulated the "response-to-injury" hypothesis of atherosclerosis and the concept of endothelial injury on basis of new data (2).

A definition of endothelial injury is problematic, since there may be a spectrum of changes in injured endothelium and many of these may have no morphologic manifestation. Knowing this, Ross formulated a subtler form of endothelial injury: "injury to the endothelium may cause no morphologic alterations but may be enough to stimulate endothelial cells to form and secrete growth factors" (2). Sources of growth factors, such as activated endothelium or macrophages, are probably sufficient to provide a mitogenic stimulus to smooth muscle cells.

Two pathways are suggested to lead to the development of advanced intimal proliferative lesions of atherosclerosis (2). One pathway, demonstrated in experimentally induced hypercholesterolemia, involves alterations in endothelium and monocytes that may result in increased monocyte adherence, subendothelial migration of monocytes that may lead to fatty streak formation and release of growth factors, and accumulation of smooth muscle cells. Fatty streaks may be directly converted to fibrous plaques through release of growth factors from macrophages (MDGF) or endothelial cells (EDGF) or both. Macrophages may also stimulate or injure the overlying endothelium. At some sites, endothellial cells may separate, and platelet attachment may occur, providing three possible sources of growth factors, platelets (PDGF), macrophages, and endothelium. But 
it is also possible that some of the smooth muscle cells in the proliferative lesion itself may form and secrete growth factors similar to a platelet derived growth factor (PDGF). The second -and alternative- pathway for development of advanced atherosclerosis involves injured endothelium, that may lead to an increased endothelial cell turnover, this may result in release of growth-factors that can induce smooth muscle migration and proliferation, and possible autogenous growth-factor release by stimulated smooth muscle cells.

\subsubsection{IN VIVO INJURY OF ENDOTHELIUM}

Animal models were used for systematic examination of the sequences of events, especially the early events, which could also lead to the development of atherosclerosis in humans. The models used, include hypercholesterolemic nonhuman primates (21-23), rat (24-26), pigeon (27,28), and swine (29-31), and the Watanabe heritable hyperlipidemic (WHHL) rabbit (32), a model for endogenous familial hypercholesterolemia.

Next to hypercholesterolemia, other models were used to induce "endothelial injury", including endothelial denudation by balloon catheters (33) air drying (34),or local freezing (35), resulting in loss of several hundreds of endothelial cells. Small intimal lesions (loss of 10-50 endothelial cells) was induced by nylon wire catheters (36), by application of an electric microcurrent $(37)$ or by laser beam $(38,39)$.

However, since it is postulated that other types of in vivo endothelial injury, such as an increased turnover, or functional injuries without cell loss, are more likely to induce atherogenesis in man and animal, only the events induced by hypercholesterolemia will be described.

\subsubsection{EXPERIMENTALLY INDUCED ATHEROSCLEROSIS BY HYPERCHOL ESTEROLEMIA}

Monkeys are used as model for the study of diet-induced atherosclerosis (21). Faggiotto $e t$ $a l$. induced chronic dietary hypercholesterolemia in nonhuman primates $(22,23)$ and described plasma cholesterol levels ranging from 13 to $26 \mathrm{mmol}$ per liter. Although these levels were high, they were within the range for patients with the hereditary disease of homozygous familial hypercholesterolemia $(40,41)$. Clusters of leukocytes -principally monocytes- were attached to the surface of the endothelium at numerous sites throughout the arterial tree. Many of these monocytes migrated subendothelially, where they accumulated lipid, and took on the appearance of foam cells. This accumulation of subendothelial macrophages constituted the first stage of fatty-streak formation in these primates. Such fatty streak expanded by continuing attachment and subendothelial migration of monocytes, and by gradual accumulation of smooth muscle cells that migrated from the media into the intima and that also accumulated lipid (22). Eventually, junctions between some endothelial cells appeared to separate over fatty streaks, located principally at branches and bifurcations, which resulted in exposure of the fatty streak, with its macrophages and their underlying connective tissue, to circulated blood. This provided 
opportunities for platelet adherence, aggregation, and thrombosis. About one or two months later advanced smooth muscle cell proliferative lesions were detected.

The importance of monocyte interactions in atherosclerosis was originally suggested by Leary (42) and has been emphasized in studies done by Gerrity $(29,30,31)$ in hypercholesterolemic swine. Additional support for an early role of the monocyte in the development of fatty streaks has come from studies of endogenous hypercholesterolemia in WHHL rabbits (32). Similar observations concerning macrophages in the development of atherosclerosis have been made in hypercholesterolemic pigeons $(27,28)$ and rats $(24-26)$.

Thus, animal studies have provided a basis for understanding the sequence of cellular interactions that cause development of atherosclerotic lesions. Further, these investigations demonstrated the importance of interactions between monocytes and a possibly altered endothelium.

\subsection{VIRUSES AND ATHEROSCLEROSIS}

Another insult that has been proposed to cause "endothelial injury", without inducing endothelial cell loss, is infection by a variety of infectious agents.

This overview, will not attempt to cover all literature on endothelial damage caused by viruses, but in vivo studies, in wich a possible relationship between herpesvirus infection and atherosclerosis is indicated, and in vitro studies of herpesvirus infection of endothelium will be discussed.

\subsubsection{EXPERIMENTALLY INDUCED ATHEROSCLEROSIS BY HERPESVIRUS INFECTION: ANIMAL MODELS}

Several animal models of viral-induced vascular disease have been described, including development of atherosclerosis in birds after herpesvirus infection.

Coxsackie virus B4, a common cardiotropic virus, caused inflammation and degenerative changes in the coronary arteries of monkeys (43). A similar observation was made in mice: Coxsackie virus $B_{4}$, recovered from a human infant, produced in mice, after intraperitoneal inoculation, arterial lesions with focal endothelial cell degeneration in the aorta and coronary arteries $(44,45)$.

Fabricant and colleagues (46-51) described the development of extensive atherosclerosis in chickens following infection with Marek's disease virus (MDV). Atherosclerotic plaques could be reproducibly induced in the chickens by MDV. Extensive proliferation of smooth muscle cells characterized the plaques observed in the intima. In contrast, regardless of the blood cholesterol level, no atherosclerotic plaques developed in noninfected chickens. By immunofluorescence, avian herpes-virus antigens were identified in smooth muscle cells within the developing lesions (50). Also virus nucleic acid sequences were detected by in situ hybridization in arteries of infected birds. Virus-induced atherosclerosis could be prevented by prior immunization with a related herpes-virus of turkeys (51).

A second avian model system for herpes-related atherosclerosis was provided by the Japanese quail. Strains of quail have been extensively inbred and they were selected for their susceptibility or resistance to cholesterol-diet induced atherosclerosis (52). Dot 
hybridisation experiments using a library of viral DNA probes showed that DNA extracted from arteries or from embryos of susceptible quail contained sequences related to the avian herpesvirus, while DNA extracted from tissues derived from resistant quail did not contain these sequences.

The mechanism of virus-induced atherogenesis was investigated by infecting cultured smooth muscle cells derived from normal chicken arteries with MDV (53). The virusinfected cells contained more cholesterol and cholesteryl esters than the mock-infected cells. By analyzing arterial tissue of infected birds it was shown that virus infection resulted in an increase in total lipids, especially cholesterol, cholesterol esters, and phospholipids (54).

Above described studies implicate an association between viruses and atherosclerosis. This involvement of herpes virus in atherogenesis prompted considerable interest in investigating a similar connection between virus and human atherosclerosis. Some viruses are capabie of producing granulomatous and immune or hypersensitive reactions in blood vessels (55), and are known to be associated primarily with myocarditis; nevertheless, none have proved to be truly atherogenic. However, an apparent association between certain viruses and arterial injury has been made (56). Burch suggested that viruses may cause fatty streaks in the arteries of infants whose few years of life have prevented them from prolonged exposure to abnormal lipoproteins $(57,58)$. This study led to an increased interest in the viral link (59-63).

\subsubsection{ASSOCIATION OF HERPESVIRIDAE WITH ATHEROSCLEROSIS IN HUMANS}

Many characteristics of the human herpesviruses, and of CMV in particular, are consistent with a role in atherogenesis. All herpesviruses are widely distributed in the population and childhood infections are common. Herpesviruses can establish both chronic persistent and latent infections. A latent infection is defined as a type of persistent infection in which the viral genome is present but infectious virus is not produced except during intermittent episodes of reactivation. (64). The site of latency for HSV and varicella zoster virus is the nervous tissue, and for Epstein-Barr virus, another member of the human herpesvirus family, the lymphocytes. The site of latency for CMV is not clear, although this virus has been detected in epithelial cells of a variety of tissues throughout the body, and in lymphocytes (65). Another feature of these viruses is related to transformation $(66,67)$.

Because of these features, latency and transformation, it has been speculated that infection of arterial smooth muscle cells by CMV or other human herpesviruses might stimulate these cells to proliferate and thereby contribute to the formation of atherosclerotic plaques. As mentioned before intimal smooth-muscle cell proliferation is seen as the key event in the development of the advanced lesions of atherosclerosis $(2,18)$.

This possibility of viral infection playing a role in the pathogenesis of human atherogenesis influenced several research groups to look for more evidence of the possible herpesvirus involvement in human atherosclerosis.

Sensitive immunocytochemical techniques, such as immunofluorescence and immunoperoxidase, in situ hybridization technique, using viral DNA probes, and the dot- 
blot DNA hybridization technique were used to screen arterial tissues for evidence of infection with HSV-1, HSV-2, and CMV.

Melnick et al. $(68,69)$ used an immunocytochemical and a hybridization technique to investigate if virus was present in cultures of smooth muscle cells derived from arterial tissue surgically removed from patients with severe arterial disease. He and his colleagues reported that human CMV-antigens (68) and CMV nucleic acid sequences (69) are present in these cultures. Examination of the proximal aorta derived from patients with severe arterial disease, by electronmicroscopy, showed herpesvirus-like particles in the endothelial and smooth muscle cells of arterial tissue (70).

In specimens of aortic tissue removed during coronary-artery-bypass surgery herpes simplex virus was also detected (71). Benditt et al. showed that nucleic acid sequences of herpes simplex virus were present in these specimens.

Adam et al. (72), showed that a higher level of antibodies against CMV was present in patients requiring vascular surgery for atherosclerosis than in a control group.

Yamashiroya et al. (73), demonstrated that HSV and CMV genomic sequences and antigens are present in areas of the coronary arteries and thoracic aortas showing early atheromatous changes, namely, focal areas of intimal thickening with smooth muscle proliferation and lymphocytic infiltration.

In another study femoral or abdominal arterial samples derived from patients undergoing vascular surgery and from an autopsy-control group who died of nonatherosclerosis-associated diseases were used. In this study Hendrix et al. $(74,75)$ demonstrated, using the more sensitive polymerase chain reaction when compared with the hybridization technique, CMV-DNA in $90 \%$ of arterial tissues of the surgical patients, compared with $53 \%$ of the autopsy-control group (75). However, as in other studies (6870,73 ) no infectious virus could be isolated from the arterial specimens.

In patients undergoing heart-transplantation a supporting evidence of herpesvirus infection, in particular CMV, playing a role in atherosclerosis was found. In these studies, a number of patients who had received heart-transplants and who were treated by immunosuppression, were followed up for the development of late graft atherogenesis in the transplanted organs and for CMV infection. It was shown that a rapid and a more frequent development of arteriosclerosis in the transplanted heart occurred after CMV infection $(76,77)$. Another study performed by McDonald et al. (78) showed also a high correlation between CMV and the subsequent development of atherosclerosis in the transplanted heart. Coronary artery disease developed in the graft in $31.3 \%$ of the CMVpositive patients, in contrast to $8.6 \%$ of the CMV-negative patients. Of these CMVpositive patients, $68 \%$ had a probability of remaining free of severe atherosclerosis at 2 years posttransplantation, in contrast to $90 \%$ for the CMV-negative patients. Hruban et al. (79) identified CMV nucleic acids in the coronary arteries of three heart transplant recipients with severe transplant-related accelerated arteriosclerosis, but not in two patients who died of other causes. The strongest hybridization was found in smooth muscle cells, although also focal endothelial cell positivity was identified (79).

In conclusion, the above described studies indicate the possibility that HSV and CMV can cause atherosclerosis or at least function as cofactors in the atherogenesis. 


\subsection{IN VITRO STUDIES: HERPESVIRUS INFECTION OF ENDOTHELIAL CELLS}

The fact that CMV and HSV imprints were detected in arterial tissues which showed minimal atherosclerotic changes suggests that virus infection could be an early event in the atherosclerotic process. The finding of viral antigens in smooth muscle cells of the media during the early stages of pathogenesis in the virus-infected chickens (50), and in humans only in smooth muscle cells at the periphery of atherosclerotic plaques, but not in the lesions themselves in advanced disease (68), supports the suggestion that virus may be an initiating factor (62).

Furthermore, it is generally believed that endothelial cell damage is the important initiating event in the pathogenesis of atherosclerosis and the following in vitro studies have shown that human herpesviruses have the ability to infect cultures of endothelial cells obtained from human umbilical veins.

In vitro studies showed that both $\mathrm{HSV}$ and CMV are able to infect endothelial cells $(66,67,80-94)$. HSV-1 replicated in cells from both human umbilical veins and bovine aorta endothelium. By immunofluorescence, viral antigen was detected within the nuclei of both cell types $(80,81)$. HSV-1 caused rapid cytolytic infections in endothelial cell cultures, no persistent infections could be determined $(80,82)$. CMV infection of cultured endothelial cells resulted in a cytopathogenic effect (CPE) present in about 10-75\% of the cells and presence of intracellular viral antigens was demonstrated $(83,84)$. The differences found in cytopathology is probably related to strain differences (84). But, CMV had also the ability to infect endothelial cell cultures without showing a detectable cytopathogenic effect (CPE) $(66,67)$. Smiley et al. (67) demonstrated that productive and persistent CMV infection of human endothelial cells in vitro resulted in a viral-induced transformation of these cells.

In 1980, MacGregor et al. (82) showed that HSV-1 infection of bovine and human endothelium in culture resulted in an augmented adherence of granulocytes. This augmented adhesion occurred before observable cytopathologic changes were detected, and it did not need antibody and complement (82). Further, it was demonstrated that infected bovine monolayers released a soluble substance that acts to increase the intensity of PMN adherence but it did not act directly on endothelial cells (82).

Later studies have indicated that HSV-1 infection of endothelial cells induces receptors for the FC portion of $\mathrm{IgG}$, glycoprotein $\mathrm{E},(85-87)$ and for $\mathrm{C} 3$, glycoprotein $\mathrm{C}(85,81)$. FC receptors were also expressed on cultured bovine pulmonary artery endothelial cells following injury by CMV (88). Zajac et al. (87) described that next to the above mentioned Fc receptor, viral glycoproteins appear at the surface following HSV-1 infection of endothelial cells, and it seemed that the increase in granulocyte adherence to HSV-1 infected endothelial cells was mediated directly by these viral glycoproteins. But also another type of increased adhesion was proposed requiring the mediation of antiviral antibodies (87). Visser et al. (89) who made a similar observation, also reported that the enhanced adherence of granulocytes caused significant cytolysis as well as detachment of viable HSV-infected endothelium from its extracellular matrix. Injury to HSV-1 infected endothelium was further enhanced by simultaneous addition of $\mathrm{Fc}$ or $\mathrm{C} 3 \mathrm{~b}$ molecules.

Thus, it seems that such receptors can play a pathogenic role by indirectly allowing the binding of viral antigen-antibody complexes that can subsequently trigger endothelial cell 
damage, or by direct attraction of $\mathrm{Fc}$ and $\mathrm{C} 3 \mathrm{~b}$ receptor bearing granulocytes to endothelial cells.

In addition, HSV-1 or CMV infection of endothelial cells resulted in endothelial procoagulant activities (90-92) and in cell surface alterations $(90,93)$. This latter phenomenon induced by HSV-1 was detected by merocyanine 540 (MC 540) staining; MC 540 intercalates in the external bilayer leaflet when lipids become loosely packed. The CMV-induced altered membrane permeability took place during virus maturation (93). The procoagulant activity induced by HSV-1 resulted from an accelerated rate of thrombin generation $(90,91)$ on the cell surface, and from a deficient prostacyclin production by endothelial cells infected with HSV-1 (99). The thrombin generation by HSV-infected cells was dependent upon the expression of glycoprotein $\mathrm{C}$, which could act as a bindingsite for factor $\mathrm{X}$ and assembly of the prothrombinase complex (91). The procoagulant response of CMV-infected human endothelial cells could also be explained by the facilitated formation of a prothrombinase complex (92). These virus-induced changes in thrombin generation were responsible for increased platelet binding (90) and monocyte adherence (91) on HSV1 -infected endothelium. Further, CMV-infection of endothelial cells resulted in a decrease of von Willebrand factor from the Weibel Palade bodies in the cytoplasm (83).

Recently, it has been described that HSV-1 infection of endothelial cells in culture inhibited their interaction with basement membrane proteins and weakened their attachment to substratum. This attachment was inadequate for proper cell spreading or movement (94). These results may help to explain endothelial vulnerability to detachment by inflammatory cells as described above, and may provide insight into vascular damage.

\subsection{ENDOTHELIAL CELL-LEUKOCYTE INTERACTION}

In vivo studies have shown that the earliest event associated with endothelial cell damage is an enhanced adhesion of leukocytes $(17,24,29,30,95,96)$.

The factors involved in the adhesive interaction between endothelial cells and leukocytes are of considerable interest. In vitro experiments revealed two mechanisms for adhesion of leukocytes to endothelial cells. The first involves activation of leukocytes (leukocyte dependent adherence). In the second mechanism endothelial cells, rather than leukocytes, are first activated causing the expression of molecules that promote leukocyte binding (endothelial cell-dependent leukocyte adhesion) $(97,98)$.

\subsubsection{LEUKOCYTE DEPENDENT ADHERENCE}

Human leukocyte adherence to cultured endothelial cells is markedly enhanced by chemotactic peptides (n-formylmethionyl-leucyl-phenylalanine [fMLP], C5a), lipid mediators (platelet activating factor [PAF] and leukotriene $\mathrm{B}_{4}[\mathrm{LTB} 4]$ ), and agents such as PMA as well as the calcium ionophore A23187. These compounds rapidly increase the neutrophil and monocyte surface expression of a multimeric membrane glycoprotein complex implicated in C3bi receptor activity and multiple adhesion-dependent leukocyte functions (99-101). The membrane complex, designated CD11/CD18, contains three distinct subunits: LFA-1 (102), Mac-1 (103) (it functions as a C3bi receptor [104]), and 
p150,95 (101), which are members of the integrin superfamily $(105,106)$. Each subunit consists of a common light-chain (B) polypeptide ( $\mathrm{M}_{\mathrm{r}} 95$ kdaltons)(CD18) that is noncovalently associated with a distinct heavy-chain $(\alpha)$ polypeptide (CD 1 1a-c).

Peripheral blood neutrophils express all three subunits of the $\cdot$ CD11/CD18 complex. This complex appears to be involved primarily in stimulated neutrophil adherence. Other neutrophil functions that are dependent on adhesive responses of stimulated cells, including C3bi binding, chemotaxis, phagocytosis of particles, antibody-dependent cytotoxicity, and aggregation, are impaired in CD11/CD18-deficient cells or normal neutrophils treated with a monoclonal antibody (MoAb) against CD18 (anti-CD18 MoAb) (107-111), which suggests that the common $B$ chain is involved in adhesion.

Like neutrophils, monocytes express all three subunits of the CD11/CD18 complex. The basal adherence of unstimulated peripheral blood monocytes to cultured endothelium is significantly, but not completely, reduced by anti-CD18 MoAb (112). Augmentation of monocyte adherence however is completely reduced by anti-CD18 MoAb (112). It thus appears that unstimulated monocyte adherence is mediated by both CD11/CD18-dependent and independent mechanisms, while stimulated adherence is only CD11/CD18 dependent.

Normal peripheral blood B- and T-lymphocytes express the LFA-1, but not the Mac-1 and p150,95 subunits. Antibodies to the CD11/CD18 inhibit T-lymphocyte mediated cytotoxicity by preventing T-lymphocyte adherence to target cells (113). Anti-CDi8 MoAbs only partially inhibit basal T-lymphocyte binding to endothelium $(114,115)$, but completely inhibit stimilated T-lymphocyte binding (159). Thus, as with monocytes, basal T-lymphocyte adherence occurs by both CD11/CD18-dependent and independent mechanisms, whereas stimulated adherence is largely CD $11 / C D 18$ dependent.

Thus, activation of neutrophils and monocytes with chemotactic peptides results in an increase in the amount of $\mathrm{CD} 11 / \mathrm{CD} 18$ complex which is a surface glycoprotein responsible for the increased adhesion to endothelial cells.

\subsubsection{ENDOTHELIAL CELL MECHANISMS}

As mentioned above next to leukocytes, endothelial cells themeselves may activily contribute to these adhesive interactions (table 1). There appear to be at least two forms of endothelial cell-dependent adhesion of leukocytes.

One occurs within minutes and is maximal in less than 1 hour (rapid response). This is independent of RNA- and protein-synthesis and has been observed after pretreatment of endothelial cells with PMA (116), $\mathrm{LTB}_{4}$ (117), thrombin (97), $\mathrm{LTC}_{4}$ or $\mathrm{LTD}_{4}$ (118), or hydrogen peroxide (119).

The other, the delayed form, induces maximal leukocyte binding at 4 to 6 hours, and gradually declines over the ensuing 24 hours. It appears to require de novo synthesis of both RNA and protein by endothelial cells since it is inhibited by actinomycin D or cycloheximide.

This latter pattern of response is observed after endothelial cell treatment with interleukin1 (IL-1)(116,120,121), tumor necrosis factor (TNF $\alpha$ ) and lymphotoxin (TNFB) (121-123), or with endotoxin (LPS) $(116,121)$. The endothelial cell surface proadhesive activity induced by endotoxin, $\mathrm{Il}-1$, or TNF acts in part via the CD11/CD18 complex since MoAb 60.3 (directed to a function-associated epitope on the B-chain polypeptide which is 
common to the 3 heterodimer subunits of the neutrophil CD18 complex: LFA-1, Mac-1, GP150,95) incompletely inhibits the increase in neutrophil adherence (121). Reduced binding is also observed in assays using CD11/CD18-deficient neutrophils (121). These findings indicate that there is an alternative mechanism for neutrophil adherence, which presumably does not require the PMN CD11/CD 18 complex.

It has been described that the cytokine-stimulated response is temporally associated with the expression of newly synthesized glycoproteins, the endothelial cell leukocyte adhesion molecules (ELAMs), that mediate polymorphonuclear leukocyte adhesion and also promote the binding of other myeloid cells (124-126). 11-1 and TNF potently augment leukocyte-endothelial cell adhesion (120) by expression of the surface molecule ELAM-1. This ELAM-1 molecule, which is maximally expressed after several hours (between 4 to 6 hours), belongs to a new gene family, the selectins. The ELAM-1 antigen is not the only surface change detectable on activated endothelial cells. IL-1, TNF, and INF- $\gamma$ also augment expression of the intercellular adhesion molecules, ICAM-1 and ICAM-2 on endothelial cells $(127,128)$. The modulation of ICAM-1 (recognized by monoclonal antibody [MoAb] RR1/1) differs from the ELAM-1 (recognized by MoAb-H4/18) protein by several criteria: MoAb-ICAM-1 binds to unstimulated endothelial cells whereas MoAbELAM-1 does not; MoAb-ICAM-1 binding reaches maximal levels by 24 hours (after IL1 , TNF and INF $\gamma$ stimulation $[128,129]$ ) and is sustained as long as IL-1 remains in the culture medium; whereas MoAb-ELAM-1 is maximal at 4 to 6 hours and declines spontaneously. Finally, MoAb-ICAM-1 binds to and is modulated on a number of cell types (129), whereas MoAb-ELAM-1 binding appears to be endothelial cell specific $(130,131)$.

The ICAM-1 is a cell-surface molecule which binds to LFA-1 (a member of the CD11/CD18 complex $[132,133])$ and regulates both leukocyte adhesion to endothelial cells and immune functions requiring cell-cell contact. However, the interaction of LFA-1 with ICAM-1 is only one of the potential mechanisms by which lymphocytes adhere to vascular endothelium $(134,135)$.

Recently, Osborn et al. (136) identified a novel protein that is induced on human endothelial cells by tumor necrosis factor (TNF- $\alpha$ ) and IL-1 and is involved in adherence of lymphocytic cell lines. This inducible endothelial adhesion protein has been designated vascular cell adhesion molecule-1 (VCAM-1). VCAM-1 is minimally expressed on unstimulated endothelial cells, but is rapidly induced by TNF, IL-1 and lipopolysaccharide (LPS) (137). VCAM is not induced on fibroblasts or arterial smooth muscle cells after stimulation with TNF.

Class II MHC antigens are also described as endothelial cell activation antigens, induced after addition of a lymphokine (IFN $\gamma)(138)($ table 1).

Further, DiCorleto and de la Motte showed that U937 cells (the human histiocytic lymphoma cell line) and peripheral blood monocytes (but not neutrophils) adhere preferentially to subconfluent or wounded endothelial cell monolayers (139). This increased surface adhesivity for monocytes in migrating or proliferating endothelial cells may represent another endothelial cell-dependent mechanism of particular importance to wound healing.

Granule membrane protein-140 (GMP-140)(140,141), which belongs also to the selectin family, is another known adhesion molecule expressed on endothelial cells. GMP140 , a membrane glycoprotein of platelet $(142,143)$ and endothelial cell $(140,144,145)$ 
secretory granules, is rapidly redistributed to the plasma membrane during cellular activation and degranulation (142,144,145). GMP-140 mediates leukocyte adhesion as demonstrated by Geng et al. (141). The leukocyte-binding did not require active neutrophil metabolism but was dependent on extracellular $\mathrm{Ca}^{2+}$. Furthermore, it seems that GMP-140 expressed by activated endothelium promotes rapid endothelial cell-dependent neutrophil adhesion: the enhanced binding is not blocked by pretreatment of endothelium with actinomycin D, an inhibitor of RNA synthesis, or by cycloheximide or emetine, inhibitors of protein synthesis.

Another example of a rapid endothelial cell-dependent adhesion mechanism, which does not belong to the adhesion molecule mechanisms, is provided by the membrane associated platelet-activating factor (PAF). Its production is induced by thrombin and other rapidly acting agonists such as LTC4 or LTD4 $(98,118,119,146)$, except PMA (147). Surface PAF is rapidly inducible and is not associated with alterations in endothelial cell morphology (148). This endothelial cell associated-PAF is a biologically active glycerophospholipid that activates polymorphonuclear leukocytes, as well as platelets and other cells, by interacting with a cell surface receptor $(149,150)$. PAF associated with the endothelial plasma membrane induces polymorphonuclear leukocyte binding. This observation is supported by experiments in which PAF in liposomes stimulated rapid polymorphonuclear leukocyte adhesion to endothelial cells and to cell-free surfaces. Competitive antagonists of the PAF receptor inhibited the binding of polymorphonuclear leukocytes to endothelial cells activated by thrombin and other rapidly acting agonists, but not to endothelial cells activated by TNF- $\alpha$, indicating again that PAF that is endogenously synthesized by endothelial cells can mediate rapid neutrophil adhesion (151).

Table 1: Cytokine modulation of endothelial cell membrane antigens.

Quantitative Binding

membrane antigen cytokine control

$$
\begin{array}{llll}
\text { IL-1 } & \text { TNF/LT } & \text { IFN } \alpha / \beta & \text { IFN }
\end{array}
$$

\begin{tabular}{lccccc}
\hline HLA-A,B & + & +++ & +++ & +++ & + \\
HLA-DR (LB3.1) & - & - & - & +++ & - \\
HLA-DQ (Leu 10) & - & - & - & + & - \\
ELAM-1 (H4/18) & +++ & +++ & - & - & - \\
ICAM-1 (RR1/1) & +++ & +++ & - & +++ & + \\
VCAM-1 (4B9) & +++ & +++ & $?$ & $?$ & +
\end{tabular}




\subsubsection{ENDOTHELIAL CELL-DERIVED OR LEUKOCYTE-DERIVED SOLUBLE MEDIATORS WHICH IPIDUCE LEUKOCYTE ADHERENCE}

The ability to secrete cytokines such as interleukins was initially considered solely a property of leukocytes. However, vascular wall cells have proven to secrete these cytokines too, as described in the following chapter.

Recent studies have established that interleukin-1 (II-1) induces a time- and dosedependent increase in adhesiveness of cultured endothelial cells that is specific for leukocytes. It augments binding of neutrophils, monocytes, monocytic-like U937 cells and HL-60 cells (120). Increased adhesiveness peaks 4-6 hours after IL-1 treatment with decay thereafter despite continued IL-1 exposure.

Various agents including LPS, TNF and IL-1 itself induce production of IL-1 in endothelial cells and in vascular smooth muscle cells (152-155); it has been identified in both its released and cell-associated form. But, IL-1 is most notably produced by nononuclear phagocytes (156). IL-1 production by endothelial cells is differently regulated zompared to the IL-1 production by mononuclear phagocytes. Zuckerman and co-workers (157) reported that dexamethasone inhibited IL-1 production in macrophages but not in endothelial cells. Il-1 is a pleiotropic cytokine which activates endothelial cells. It alters the functional properties of vascular cells including:

(i) the arachidonate metabolism: stimulation of the $\mathrm{PGI}_{2}$ production $(158,159)$ by increasing the levels of the enzyme cyclooxygenase and the avaibility of arachidonate, which is an inhibitor of platelet aggregation and a potent vasodilator;

[ii] changes in antithrombotic properties: by inducing the tissue-type procoagulant activity (160), IL-1 suppresses the cell surface anticoagulant activity mediated by the thrombomodulin protein C pathway (161); IL-1 shifts the fibrinolytic properties of endothelial cells by decreasing tissue-type plasminogen activator and augmenting the production of an inhibitor of plasminogen activator $(162,163)$; IL-1 increases the production of PAF (164), which activates platelets and leukocytes.

[iii] leukocyte recruitment (165): indirectly by changing the adhesive properties of endothelial cells by expression of adhesion structures (as described above) $(125,134)$ and by inducing production of chemotactic cytokines, such as CSF, IL-8, MCP-1 (166-168), and other cytokines (Il-1, IL-6, CSF [156,169]).

In addition, Il-1 modulates /iv/ the growth of vascular cells: the proliferation of endothelial cells is inhibited while the growth of smooth muscle cells and fibroblasts is promoted to some extent $(170,171)$. The activity of $11-1$ on smooth muscle cells, but not on endothelial cells is influenced by the induction of inhibitory prostaglandins: stimulation of cell proliferation was observed after inhibition of the arachidonate metabolism (172). Il-1 induces platelet derived growth factor (PDGF) release by endothelial cells and smooth muscle cells. This could also account for its effect in increasing proliferation of smooth muscle cells and fibroblasts (170). This mitogen has no effect on endothelial cells (148).

Tumor necrosis factor (TNF) is a cytokine produced by macrophages and $\mathrm{T}$ cells. It induces endothelial proadhesive effects identical to those observed by Il-1 (173). TNF induces release of endothelial cell-derived IL-1 (174), stimulates $\mathrm{PGI}_{2}$ production (175), procoagulant activity (176), tissue type plasminogen activator (177), and PAF (178); induces expression of adhesion structures for leukocytes (173), expression of chemotactic 
cytokines and CSF (8); TNF induces migration, but inhibits proliferation, of endothelial cells (156).

TNF differs from Il-1 in that it rapidly augments neutrophil surface expression of the CD11/CD18 complex (121). Lymphotoxin (LT or TNFB) is a related cytokine produced by $\mathrm{T}$ and $\mathrm{B}$ lymphocytes, which acts via the same receptor and has activities similar to those of TNF. TNF and Il-1 are additive at optimal concentrations in inducing various endothelial cell responses including procoagulant activity, neutrophil adhesion molecules and CSF production $(176,179)$.

Exposure to poly(I):poly(C) or virus induces production of interferon (IFN) $\alpha$ and $\beta$ in endothelial cells (180). Endothelial cells also produce large amounts of interleukin-6 (IL-6 $\left[I N F-\beta_{21}\right.$ ) after exposure to above mentioned stimuli (181). However, levels of spontaneous IL-6 production were also detected (169), though one cannot exclude the possibility that this reflects response to yet unidentified signals present in in vitro culture system. Il-1, TNF, and LPS enhance IL- 6 mRNA and protein in endothelial cells. Il- 6 does not induce the functional changes in endothelial cells elicited by IL-1 (169). Il-6 is a pleiotropic lymphokine that affects the proliferation of T- and B-cells, has CSF-activity and regulates the production of acute phase proteins in the liver (182).

Furthermore, it is known that endothelial cells and leukocytes release colony stimulating factors (CFSs) $(156,166,167,183)$ : granulocyte $(\mathrm{G})$-, granulocyte-macrophage (GM)-, and Macrophage (M)-CSF have been identified. Various stimuli including IL-1, TNF, and LPS induce endothelial production of CSFs. Viral infection of endothelial cells altered elaboration of GM-colony stimulating activity (184). By producing CSFs (including IL-1 and IL-6, which have CSF activity), endothelial cells participate in the regulation of hematopoietic stem cells to mature neutrophils and monocytes, and they induce migration and proliferation of endothelial cells (185), and recruitment and activation of leukocytes $(156,166,186,187)$. G- and GM-CSF do not stimulate the proinflammatory/prothrombotic properties of endothelial cells.

Endothelial cells also release chemoattractants, different from G- or GM-CSF, that induce the locomotion of polymorphonuclear cells and monocytes: antibodies directed against G- and GM-CSF only partially inhibit the chemotactic activity of endothelial cell supernatants (156).

In relation to atherosclerosis, the monocyte chemo-attractant family characterized by monocyte chemotactic and activating factor (MCAF), also known as monocyte chemotactic peptide (MCP-1), has particular interest. MCAF/MCP-1 is secreted by endothelial cells, smooth muscle cells, and macrophages (8). This protein shares some sequence similarity with the interleukin-8 cytokine (188).

Endothelial cells produce upon stimulation with IL-1, TNF, or LPS, monocyte-derived neutrophil chemotactic factor (MDNCF)/IL-8 activity. IL-8 is a chemotactic factor for PMN and T cells, and is an activator of certain granulocyte functions (189-192). Endothelial IL-8 can act as a leukocyte adhesion inhibitor or as a chemoattractant $(192,193)$.

The action of gamma-interferon (IFN $\gamma$ ), produced by activated $\mathrm{T}$ cells present in the atherosclerotic lesion (8), on endothelial cells is unique and distinct from IL-1, TNF and other cytokines. IFN $\gamma$ induces endothelial cells to act as accessory cells without inducing proinflammatory/prothrombotic or proliferative/migratory activities. IFN $\gamma$ augments the expression of MHC class I antigens and induces class II antigens on endothelial cells 
$(138,194) . \quad$ IFN $\gamma$ augments the production of IL-1 by LPS-stimulated endothelial cells (153). IFN $\gamma$ inhibits both endothelial cell growth by down regulating fibroblast growth factor (FGF) receptors (195) and smooth muscle cell growth in vitro. Further IFN $\gamma$ induces a slow increase in ICAM-1 expression (128).

Activated mononuclear phagocytes produce transforming growth factor B (TGF- $B$ ), TGF- $\alpha$ and fibroblast growth factor (FGF) (196). TGF- $\alpha$ stimulates smooth muscle cells, while TGF- $\beta$ inhibits both smooth muscle cell proliferation and endothelial cell proliferation, and activation of $\mathrm{T}$ and B lymphocytes $(197,198)$, but it stimulates capillary tube formation when endothelial cells are grown in a three-dimensional collagen gel $(199,200)$. TGF- $\beta$ also inhibits endothelial cell chemotaxis and the effect of IL-1 and TNF on neutrophil adhesion to endothelial cells (201).

In conclusion, cytokines play a role as communication signals between vascular endothelial cells and leukocytes. Various cytokines are produced by and act on endothelial cells and the responses elicited seem to follow discrete, essentially non-overlapping patterns. From above described studies and other studies endothelial cells seem to be active participants in the induction and regulation of coagulation, inflammation and immunity; and cytokines are crucial mediators of the symbiotic bidirectional interaction between vascular cells and leukocytes.

\subsection{REFERENCES}

1. Harker LA: Platelets, endothelial injury, and atherosclerosis. In: Steinberg D, Olefsky JM (eds) Contemporary issues in atherosclerosis. Churchill Livingstone, Edinburgh, New York, pp 25-52.

2. Ross R: The pathogenesis of atherosclerosis-an update. N Engl J Med 314: 488, 1986.

3. Gown AM, Tsukada T, Ross R: Human atherosclerosis II. Immunocytochemical analysis of the cellular composition of human atherosclerotic lesions. Am J Pathol 125: 191, 1986.

4. Jonasson L, Holm J, Skalli O, Bonders G, Hansson GK: Regional accumulation of $T$ cell, macrophages, and smooth muacle cells in the human atherosclerotic plaque. Arteriosclerosis 6: 131, 1986.

5. Jonasson L, Holm J, Skalli $O$, Bonders G, Hansson GK: Regional accumulations of $T$ cells, macrophages, and smooth muscle cells in the human atherosclerotic plaque. Arteriosclerosis 6: 131, 1986.

6. Emeson EE, Robertson AL Jr: $\mathrm{T}$ lymphocytes in aortic and coronary intimas. Am J Pathol 130: $369,1988$.

7. Ramshaw AL, Parums DV: Immunohistochemical characterization of inflammatory cells associated with advanced atherosclerosis. Histopathology 17: 543, 1990.

8. Libby P, Hansson GK: Biology of disease. Involvement of the immune system in human atherogenesis: current knowledge and unanswered questions. Lab Invest 64: 5, 1991.

9. Robertson AL: The pathogenesis of human atherosclerosis. In: Atherosclerosis, a scope publication, Upjohn, Kalamazoo, 1977.

10. Clowes AW, Schwartz SM: Significance of quiescent smooth muscle migration in the injured rat carotid artery. Circ Res 56: 139, 1985.

11. Schwartz SM, Reidy MR, Clowes AW: Kinetics of atherosclerosis, a stem cell model. Ann NY Acad Sci 454: 292, 1985.

12. Ross R: Atherosclerosis-a problem of the biology of arterial wall cells and their interactions with blood components. Arteriosclerosis 1: 293, 1981. 
13. Ross R: Atherosclerosis and the arterial snooth muscle cell. Science 180: 1332, 1973.

14. Ross R, Harker L: Hyperlipidemia and atherosclerosis. Science 193: 1094, 1976.

15. Ross R: Atherosclerosis: a question of endothelial integrity and growth control of smooth muscle cell. Harvey Lect 77: 161, 1981-1982.

16. Ross R, Wight TN, Strandness E, Thiele B: Human atherosclerosis. 1. Cell constitution and characteristics of advanced lesions of the superficial femoral artery. Am J Pathol 114: 79, 1984.

17. Faggiotto A, Ross R: Studies of hypercholesterolemia in nonhuman primate. II. Fatty streak conversion to fibrous plaque. Arteriosclerosis 4: 341, 1984.

18. Ross R, Glomset J: The pathogenesis of atherosclerosis. N Engl J Med 295: 369, 1976.

19. Harker LA, Ross R, Slichter SJ, Scott C: Homocystine-induced arteriosclerosis: The role of endothelial cell injury and platelet response in its genesis. J Clin Invest 58: 731, 1976.

20. Moore S. In "Vascular injury and atherosclerosis" (S.Moore, ed.), pp 131-148, Marcel Dekker, NY, 1981.

21. Wissler RW, Vesselinovitch D: Atherosclerosis in nonhuman primates. Adv Vet Sci Comp Med 21: $351,1977$.

22. Faggiotto A, Ross R: Studies of hypercholesterolemia in the nonhuman primate. I. Changes that lead to fatty streak formation. Arteriosclerosis 4: 323, 1984.

23. Faggiotto A, Ross R: Studies of hypercholesterolemia in the nonhuman primate.ll. Fatty streak conversion to fibrous plaque. Arteriosclerosis 4: 341, 1984.

24. Joris I, Zand T, Nunnari JJ, Krolikowski FJ, Majno G: Studies on the pathogenesis of atherosclerosis I. Adhesion and emigration of mononuclear cells in the aorta of hypercholesterolemic rats. Am J Pathol 113: 341, 1983.

25. Gabaldon M, Capdevila C: Adhesion of leukocytes to the aortic endothelium of conventional, specific pathogen free (SPF) and hypercholesterolemic SPF rats. Atherosclerosis 75: 83, 1989.

26. Nakamura H, Izumiyama N, Nakamura K, Ohtsubo K: Age-associated ultrastructural changes in the aortic intima of rats with diet-induced hypercholesterolemia. Atherosclerosis 79: 101, 1989.

27. Lewis JC, Taylor RG, Jones ND, St Clair RW, Comhill JF: Endothelial surface characteristics in pigeon coronary artery atherosclerosis. I. Cellular alterations during the initial stages of dietary cholesterol challenge. Lab Invest 46: 123, 1982.

28. Jerome WG, Lewis JC: Early atherogenesis in white carneau pigeons. I. Leukocyte margination and endothelial alterations at the celiac bifurcation. Am J Pathol 116:56, 1984.

29. Gerrity RG, Naito HK, Richardson M, Schwartz CJ: Dietary induced atherogenesis in swine: Morphology of the intima in prelesion stages. Am J Pathol 95: 775, 1979.

30. Gerrity RG: The role of the monocyte in atherogenesis. I. Transition of blood borne monocytes into foam cells in fatty lesions. Am J pathol 103: 181, 1981.

31. Gerrity RG: The role of the monocyte in atherogenesis. II. Migration of foam cells from atherosclerotic lesions. Am J pathol 103: 191, 1981.

32. Rosenfield ME, Faggiotto A, Ross $R$ : The role of the mononuclear phagocyte in primate and rabbit models of atherosclerosis. Proceedings of the Fourth Leiden Conference on Mononuclear Phagocytes. The Hague: Martinus Nijhoff, pp795, 1985.

33. Schwartz SM, Haudenschild CC, Eddy EM: Endothelial regeneration. 1. Quantitative analysis of intimal stages of endothelial regeneration in rat aortic intima. Lab Invest 38: 569, 1978.

34. Fishman JA, Ryan GB, Karnovsky MJ: Endothelial regeneration in the rat carotid artery and the significance of endothelial denudation in the pathogenesis of myointimal thickening. Lab Invest 32 : $339,1975$.

35. Malczak HT, Buck RC: Regeneration of endothelium in rat aorta after local freezing: a scanning electron microscopy study. Am J Path 86: 133, 1977.

36. Reidy MA, Schwartz SM: Endothelial regeneration. III. A technique to investigate surface morphology and endothelial cell replication of small arteries: a study in acute angiotensin-induced hypertensive rats. Microvasc Res 24: 158, 1982.

37. Maes L, Andries R, Bourgain RH: Endothelial injury and platelet thrombosis in mesenteric arteries of rats: a scanning electron microscopic study. Blood Vessels $23: 1,1986$. 
38. Kovacs IB, Görög P: Laser-induced thrombosis test suitable for pharmacologic screening studies. Microvasc Res 18: 403, 1979.

39. Weichert $W$, Paulins V, Breddin RK: Laser-induced thrombi in rat mesenteric vessels and antithrombotic drugs. Haemostasis 13: 61, 1983.

40. Goldstein JL, Kita T, Browns MS: Defective lipoprotein receptors and atherosclerosis: Lesions from an animal counterpart of familial hypercholesterolemia $\mathrm{N}$ Engl J Med 309: 288, 1983.

41. Brown MS, Goldstein JL: How LDL receptors influence cholesterol and atherosclerosis. Sci Am 251: $58,1984$.

42. Leary T: The genesis of atherosclerosis. Arch Pathol 32: 507, 1941.

43. Sun SC, Sohal RS, Burch GE, Chu KC, Colcolough HL: Coxsacky virus B4 pancarditis in cynomolgus monkey resembling rheumatic heart lesions. Br J Exp Pathol 48: 655, 1967.

44. Burch GE, Tsui CY, Harb JM: Pathologic changes of aorta and coronary arteries of mice infected with coxsackie $B_{4}$ virus (35641). Proc Soc Exp Biol Med 137: 657, 1971.

45. Campbell AE, Loria RM, Madge GE: Coxsackievirus B cardiopathy and angiopathy in the hypercholesterolemic host. Atherosclerosis 31:295, 1978.

46. Fabricant CG, Krook L, Gillespie JH: Virus-induced cholesterol crystals. Science 181: $566,1973$.

47. Fabricant CG, Fabricant J, Litrenta MM, Minick CR: Virus-induced-atherosclerosis. J Exp Med 148: 335,1978 .

48. Minick CR, Fabricant CG, Fabricant J, Litrenta MM: Atheroarteriosclerosis induced by infection with a herpesvirus. Am J Pathol 96: 673, 1979.

49. Fabricant CG, Fabricant J, Minick CR, Litrenta MM: Herpesvirus induced atherosclerosis. In: Viruses in naturally occuring cancers. Cold Spring Harbor Conferences on cell proliferation, vol 7, book B. Essex M, Todaro G, zür Hausen, eds Cold Spring Harbor Laboratory, pp 1251, 1980.

50. Fabricant CG: Herpesvirus-induced atherosclerosis. Diabetes 30 (suppl.2): 29, 1981.

51. Fabricant CG, Fabricant J, Minick CR, Litrenta MM: Herpesvirus-induced atherosclerosis in chickens. Fed Proc 42: 2476, 1983.

52. Shih JCH, Pullman EP, Kao KJ: Genetic selection, general characterization and histology of atherosclerosis-susceptible and -resistant Japanese quail. Atherosclerosis 49: 41, 1983.

53. Fabricant CG, Hajjar DP, Minick CR: Lipid accumulations in cultured vascular smooth muscle cells infected with Marek's disease herpesvirus. Fed Proc 39: 1110, 1980.

54. Hajjar DP, Fabricant CG, Minick CR, Fabricant J: Virus-induced atherosclerosis - herpesvirus infection alters aortic cholesterol metabolism and accumulation. Am J Pathol 122: 62, 1986.

55. Robbins SL, Cotran RS, Kumar V: Pathologic basis of disease, WB Saunders Company, Philadelphia, PA, pp593, 1984.

56. Burch GE, Harb JM, Hiramoto $Y$, Shewey L: Viral infection of the aorta of man associated with early atherosclerotic changes. Am Heart J 86: 523, 1973.

57. Burch GE: Viruses and atherosclerosis. Am Heart J 87: 407, 1974.

58. Burch GE: Of atherosclerosis in infants and children and viral infections. Am Heart $\mathrm{J} 96: 107$, 1978.

59. Kolata G: Virus-heart link studied. Science 227: 735, 1985.

60. Virella G, Virella MF: Infections and atherosclerosis. Transplant Proc 4 (suppl 5): $26,1987$.

61. Culliton BJ: Endothelial cells to the rescue. Science 246: 749, 1989.

62. Melnick JL, Adam E, Debakey ME: Possible role of cytomegalovirus in atherogenesis-special communication. JAMA 263: 2204, 1990.

63. Mozar NH, Dileep GB, Farag SA: The natural history of atherosclerosis: An ecologic perspectiveviewpoint. Atherosclerosis 82: 157, 1990.

64. Stevens JC: Human herpesviruses: A consideration of the latent state. Microbiol Rev 53: $318,1989$.

65. Schrier RD, Nelson JA, Oldstone MBA: Detection of human cytomegalovirus in peripheral blood lymphocytes in a natural infection. Science 230: 148, 1985.

66. Gönczöl E, Boldogh I, Vaczi L: IgG-Fc-binding receptors in cells abortively infected, or transformed, by human cytomegalovirus. Acta Microbiol Acad Sci Hung 28: 157, 1981.

67. Smiley ML, Mar E-C, Huang E-S: Cytomegalovirus infection and viral-induced transformation of human endothelial cells. J Med Virol 25: 213, 1988. 
68. Melnick JL, Petrie BL, Dreesman GR, McCollum CH, Burek J, DeBakey ME: Cytomegalovirus antigen within human arterial smooth muscle cells. Lancet 2: 644, 1983.

69. Petrie BL, Melnick JL, Adam E, Burek J, McCollum CH, DeBakey ME: Nucleic acid sequences of cytomegalovirus in cells cultured from human arterial tissue. J Infect Dis 155: 158, 1987.

70. Gyorkey F, Melnick JL, Guinn GA, Gyorkey P, DeBakey ME: Herpesviridae in the endothelial and smooth muscle cells of the proximal aorta in arteriosclerotic patients. Exp Mol Pathol 40: 328, 1984.

71. Benditt EP, Barrett T, McDougall JK: Viruses in the etiology of atherosclerosis. Proc Natl Acad Sci USA 80: 6386, 1983.

72. Adam E, Probisfield JL, Burek J, McCollum CH, Melnick JL, Petrie BL, Dailey KR, DeBackey ME: High levels of cytomegalovirus antibody in patient requiring vascular surgery for atherosclerosis. Lancet 8554: 291, 1987.

73. Yamashiroya HM, Ghosh L, Yang R, Robertson AL Jr: Herpesviridae in the coronary arteries and aorta of young trauma victims. Am J Pathol 130: 71, 1988.

74. Hendrix MGR, Dormans PHJ, Kitslaar P, Bosman F, Bruggeman CA: The presence of cytomegalovirus nucleic acids in arterial walls of atherosclerotic and nonatherosclerotic patients. Am J Pathol 134: 1151, 1989.

75. Hendrix MGR, Salimans MMM, van Boven CPA, Bruggeman CA: High prevalence of latently present cytomegalovirus in arterial walls of patients suffering from grade III atherosclerosis. Am J Pathol 136: 23, 1990.

76. Wreghitt TG, Hakim M, Gray JJ, Kucia S, Cory-Pearce R, Wallwork J, English TAH: A detailed study of cytomegalovirus infections in the first 160 heart and heart/lung transplant recipients at Papworth Hospital, Cambridge, England. Transplant Proc 19: 2495, 1987.

77. Grattan MT, Moreno-Cabral CE, Starnes VA, Oyer PE, Stinson EB, Shumway NE: Cytomagalovirus infection is associated with cardiac allograft rejection and atherosclerosis. JAMA 261: 3561, 1989.

78. McDonald K, Rector TS, Braunlin EA, Kubo SH, Olivari MT: Association of coronary artery disease in cardiac transplant recipients with cytomegalovirus infection. Am J Pathol 64: 359, 1989.

79. Hruban RH, Wu T-C, Beschomer WE, Cameron DE, Ambinder RF, Baumgartner WA, Reitz BA, Hutchins GM: Cytomegalovirus nucleic acids in allografted hearts. Human Pathol 21: 981, 1990

80. Friedman HM, Macarak EJ, MacGregor RR, Wolfe J, Kefalides NA: Virus infection of endothelial cells. J Infect Dis 143: 266, 1981.

81. Friedman HM, Cohen GH, Eisenberg RJ, Seidel CA, Cines DB: Glycoprotein C of herpes simplex virus acts as a receptor for the C3b complement component on infected cells. Nature 309: 633, 1984.

82. MacGregor RR, Friedman HM, Macarek EJ, Kefalides NA: Virus infection of endothelial cells increases granulocyte adherence. J Clin Invest 65: 1469, 1980.

83. Bruggeman CA, Debie WHM, Muller AD, Schutte B, van Dam-Mieras: Cytomegalovirus alters the von Willebrand factor content in human endothelial cells. Thromb Haemostasis 59: 264, 1988.

84. Waldman WJ, Sheddon JM, Stephens RE, Roberts WH: Enhanced endothelial cytopathogenecity induced by a cytomegalovirus strain propagated in endothelial cells. J Med Virol 28: 223, 1989.

85. Cines DB, Lyss AP, Bina M, Corkey R, Kefalides NA, Friedman HM: Fc and C3 receptors induced by herpes simplex virus on cultured human endothelial cells. J Clin Invest 69: 123, 1982.

86. Para MF, Baucke RB, Spear PG: Glycoprotein E of herpes simplex virus type 1: Effects of anti-gE on virion infectivity and on virus induced Fc-binding receptors. J Virol 41: 129, 1982.

87. Zajac BA, O'Neill K, Friedman HM, MacGregor RR. Increased adherence of human granulocytes to herpes simplex virus type 1 infected endothelial cells. In vitro Cell Devel Biol 24: 321, 1988.

88. Ryan US, Schultz DR, Ryan JW: Fc and C3b receptors on pulmonary endothelial cells: induction by injury. Science 214: 557, 1981.

89. Visser MR, Jacob HS, Goodman JL, McCarthy JB, Furcht LT, Vercellotti GM: Granulocytemediated injury to herpes simplex virus-infected human endothelium. Lab Invest 60: 296, 1989. 
90. Visser MR, Tracy PB, Vercellotti GM, Goodman JL, White JG, Jacob HS: Enhanced thrombin generation and platelet binding on herpes simplex virus-infected endothelium. Proc Natl Acad Sci USA 85: 8227, 1988.

91. Etingin OR, Silverstein RL, Friedman HM, Hajjar DP: Viral activation of the coagulation cascade: Molecular interactions at the surface of infected endothelial cells. Cell 61: 657, 1990.

92. Van Dam-mieras MCE, Muller AD, van Hinsbergh VWM, Mullers WJHA, Bruggeman CA: The procoagulant response of cytomegalovirus infected endothelial cells. Submitted for publication.

93. Rugolo M, Baldassarri $B$, Landini MP: Changes in membrane permeability in cells infected by human cytomegalovinus. Arch Virol 89, 203, 1986.

94. Visser MR, Vercellotti GM, MCCArthy JB, Goodman JL, Herbst TJ, Furcht LT, Jacob HS: Herpes simplex virus inhibits endothelial cell attachment and migration to extracellular matrix proteins. Am J Pathol 134: 223, 1989.

95. Fowler S, Berberian PA, Shio H, Goldfischer S, Wolinsky H: Characterization of cell populations isolated from aortas of rhesus monkeys with experimental atherosclerosis. Circ Res 46: 520, 1980.

96. Fowler S, Shio H, Haley NJ: Characterization of lipid-laden aortic cells from cholesterol-fed rabittis. IV. Investigation of macrophage-like properties of aortic cell populations. Lab Invest 41 : $372,1979$.

97. Zimmerman GA, McIntyre TM, Prescott SM. Thrombin stimulates the adherence of neutrophils to human endothelial cells in vitro. J Clin Invest 76: 2235 (1985).

98. Zimmerman GA, McIntyre TM, Prescott SM. Thrombin stimulates neutrophil adherence by an endothelial cell-dependent mechanism: Characterization of the response and relationship to plateletactivating factor synthesis. Ann NY Acad Sci 485: 349, 1986.

99. Harlan JM, Killen PD, Senecal FM, Schwartz BR, Yee EK, Taylor RF, Beatty PG, Price TH, Ochs HD: The role of neutrophil membrane glycoprotein GP-150 in neutrophil adherence to endothelium in vitro. Blood 66: 167, 1985 .

100. Amaout MA, Spits H, Terhorst C, Pitt J, Todd RF III: Deficiency of a leukocyte surface glycoprotein (LFA-1) in two patients with Mol deficiency. Effects of cell activation on Mol/LFA-1 surface expression in normal and deficient leukocytes. J Clin Invest 74: 1291, 1984.

101. Sanchez-Madrid F, Nagy JA, Robbins E, Simmon P, Springer TA. A human leukocyte differentiation antigen family with distinct $\alpha$-subunits and a common $\beta$-subunits: The lymphocyte function-associated antigen (LFA-1), the C3bi complement receptor (OKM1/Mac-1), and pl50,95 molecule. J Exp Med 158; 1785, 1983.

102. Davignon D, Martz E, Reynolds $T$, Kurzinger $K$, Springer TA: Lymphocyte function-associated antigen-1 (LFA-1): A surface antigen distinct from Lyt-2,3 that participates in T-lymphocytemediated killing. Proc Natl Acad Sci USA 78: 4535, 1981.

103. Todd RF, Van Agthovern A, Schlossman SF, Terhorst C: Structural analysis of differentiation antigens Mo1 and Mo2 on human monocytes. Hybridoma 1: 329, 1982.

104. Wright SD, Rao PE, Van Voornis WC, Craigmyle LS, Lida K, Talle MA, Westberg EF, Goldstein $\mathrm{G}$, Silverstein SC: Identification of the C3bi receptor of human monocytes and macrophages by using monoclonal antibodies. Proc Natl Acad Sci USA 80: 5699, 1983.

105. Anderson DC, Miller L, Schmalsteig FC, Rothlein R, Springer TM: Contribution of the Mac-1 glycoprotein family to adherence-dependent granulocyte functions: Structure-function assessments employing subunit-specific monoclonal antibodies. J Immunol 137: 15, 1986.

106. Kishimoto TK, O'Connor K, Lee A, Roberts TM, Springer TM: Cloning of the B-subunit of the leukocyte adhesion proteins: Homology to an extraceilular matrix receptor defines a novel supergene family. Cell 48: $681,1987$.

107. Weisman SJ, Berkow RL, Plautz G, Torres M, McGuire WA, Coates TD, Haak RA, Floyd A, Jersild R, Baehner RL: Glycoprotein-180 deficiency: Genetics and abnormal neutrophil activation. Blood 65: 696, 1985.

108. Buescher ES, Gaither T, Nath J, Gallin JI: Abnormal adherence-related functions of neutrophils, monocytes, and Epstein-Barr virus-transformed $B$ cells in a patient with $C 3 b i$ receptor deficiency. Blood 65: 1382, 1985. 
109. Anderson DC, Schmalstieg FC, Arnaout MA, Kohl S, Tosi MF, Dana N, Buffone GJ, Hughes BJ, Brinkley BR, Dickey WD, Abramson JS, Springer T, Boxer LA, Hollers JM, Smith CW: Abnormalities of polymorphonuclear leukocyte function associated with a heritable deficiency of high molecular weight surface glycoproteins (GP138): Common relationship to dimished cell adherence. J Clin Invest 74: 536, 1984.

110. Springer TA, Thompson WS, Miller LJ, Schmalstieg FC, Anderson DC: Inherited deficiency of the Mac-1, LFA-1, p150,95 glycoprotein family and its molecular basis. J Exp Med 160: 1901, 1984.

111. Schwartz BR, Ochs HD, Beatty PG, Harlan JM: A monoclonal antibody-defined membrane antigen complex is required for neutrophil-neutrophil aggregation. Blood 65: 15531985.

112. Wallis WJ, Beatty PG, Ochs HD, Harlan JM: Human monocyte adherence to cultured vascular endothelium: Monoclonal antibody-defined mechanisms. J Immunol 135: 2323, 1985.

113. Krensky AM, Robbins E, Springer TA, Burakoff SJ: LFA-1, LFA-2, and LFA-3 antigens are involved in CTL-target conjugation. J Immunol 132: 2180, 1984.

114. Mentzer SJ, Burakoff SJ, Faller DV: Adhesion of T-lymphocytes to human endothelial cells is regulated by the LFA-1 membrane molecule. J Cell Physiol 126: 285, 1986.

115. Haskard D, Cavender D, Beatty P, Springer T, Ziff M: T lymphocyte adhesion to endothelial cells: Mechanisms demonstrated by anti-LFA-1 monoclonal antibodies. J Immunol 137: 290I, 1986.

116. Schleimer RP, Rutledge BK: Cultured human vascular endothelial cells acquire adhesiveness for neutrophils after stimulation with interleukin 1, endotoxin and tumor-promoting phorbol diesters. J Immunol 136: 649, 1986.

117. Hoover RL, Karnovsky MJ, Austen KF, Corey EJ, Lewis RA: Leukotriene $B_{4}$ action on endothelium mediates augmented neutrophil/endothelial adhesion. Proc Natl Acad Sci USA 81 : 2204, 1984.

118. Mcintyre TM, Zimmerman GA. Prescott SM: Leukotrienes $C_{4}$ and $D_{4}$ stimulate human endothelial cells to synthesize platelet-activating factor and bind neutrophils. Proc Natl Acad Sci USA 83: 2204 , 1986.

119. Lewis MS, Whatley RE, Cain PC, McIntyre TM, Prescott SM, Zimmerman GA: Hydrogen peroxide stimulates the synthesis of platelet-activating factor by endothelium and induces endothelial cell-dependent neutrophil adhesion. J Clin Invest 82: 2045, 1988.

120. Bevilacqua MP, Pober JS, Wheeler MJ, Cotran RS, Gimbrone MA. Interleukin 1 interacts on cultured human vascular endothelium to increase the adhesion of polymorphonuclear leukocytes, monocytes, and related leukocyte cell lines. J Clin Invest 76: 2003, 1985.

121. Pohlman TH, Stanness KA, Beatty PG, Ochs HD, Harlan JM: An endothelial cell surface factor(s) induced in vitro by lipopolysaccharide, interleukin-1, and tumor necrosis factor- $\alpha$ increases neutrophil adherence by a CDw18-dependent mechanism. J Immunol 136: 4548, 1986.

122. Gamble JR, Harlan JM, Klebanoff SJ, Vadas MA: Stimulation of the adherence of neutrophils to umbilical vein endothelium by human recombinant tumor necrosis factor. Proc Natl Acad Sci USA 82: $8667,1985$.

123. Broudy VC, Harlan JM, Adamson JW: Disparate effects of tumor necrosis factor- $\alpha /$ cachetin and tumor necrosis factor-\$/lymphotoxin on hemopoetic growth factor production and neutrophil adhesion molecule expression by cultured human endothelial cells. J Immunol 138: 4298, 1987.

124. Bevilacqua MP, Pober JS, Mendrick DL, Cotran RS, Gimbrone MA: Identification of an inducible endothelial-leukocyte adhesion molecule. Proc Natl Acad Sci USA 84: 9238, 1987.

125. Bevilacqua MP, Stengelin S, Gimbrone MA Jr, Seed B: Endothelial leukocyte adhesion molecule 1: An inducible receptor for neutrophils related to complement regulatory proteins and lectins. Science 243: $1160,1989$.

126. Bobrina A, Schwartz BR, Carlos TM, Ochs HD, Beatty PG, Harlan JM: CD11/CD18-independent neutrophil adherence to inducible endothelial-leukocyte adhesion molecules (E-LAM) in vitro. Immunology 67: 502, 1989.

127. Pober JS, Gimbrone MA Jr, Lapierre LA, Mendrick DL, Fiers W, Rothlein R, Springer TA: Overlapping patterns of activation of human endothelial cells by interleukin 1 , tumor necrosis factor, and immune interferon. J Immunol 137: 1893, 1986. 
128. Rothlein R, Czajkowski M, O'Neill MM, Marlin SD, Mainolfi E, Merluzzi VJ: Induction of intercellular adhesion molecule 1 on primary and continuous cell lines by proinflammatory cytokines. J Immunol 141: 1665, 1988.

129. Dustin ML, Rothlein R, Bhan AK, Dinarello CA, Springer TA: Induction of IL-1 and interferon- $\gamma$, tissue distribution, biochemistry and function of a natural adherence molecule (ICAM-1). J Immunol 137: $245,1986$.

130. Pober JS, Bevilacqua MP, Mendrick DL, Lapierre LA, Fiers W, Gimbrone MA Jr: Two distinct monokines, interleukin 1 and tumor necrosis factor, each independently induce biosynthesis and transcient expression of the same antigen on the surface of cultured human vascular endothelial cells. J Immunol 136: 1680, 1986.

131. Nawroth PP, Stern DM: Modulation of endothelial cell hemostatic properties by tumor necrosis factor. J Exp Med 163: 740, 1986.

132. Rothlein R, Dustin ML, Marlin SD, Springer TA: A human intercellular adhesion molecule (ICAM1) distinct from LFA-1. J Immunol 137: 1270, 1986.

133. Staunton DE, Dustin ML, Springer TA: Functional cloning of ICAM-2, a cell adhesion ligand for LFA-1 homologous to ICAM-1. Nature 339: 61, 1989.

134. Dustin ML, Springer TA: Lymphocyte function associated antigen-1 (LFA-1) interaction with intercellular adhesion molecule-1 (ICAM-1) is one of at least three mechanisms for lymphocyte adhesion to cultured endothelial cells. J Cell Biol 107: 321, 1988.

135. Haskard DO, Strobel S, Thornhill M, Pitzalis C, Levinsky RJ: Mechanisms of lymphocyte adhesion to endothelial cells: Studies using a LFA-1-deficient cell line. Immunology 66: 111, 1988.

136. Osbom L, Hession C, Tizard R, Vassallo C, Luhowskyj S, Chi-Rosso G, Lobb R: Direct expression cloning of vascular adhesion molecule-1 (VCAM-1), a cytokine induced endothelial protein that binds to lymphocytes. Cell 59: 1203, 1989.

137. Carlos TM, Schwartz BR, Kovach NL, Rosso EYM, Osborn L, Chi-Rosso G, Newman B, Lobb R, Harlan JM: Vascular cell adhesion molecule-1 mediates lymphocyte adherence to cytokine-activated cultured human endothelial cells. Blood 76, 965, 1990;

138. Pober JS, Gimbrone MA Jr, Cotran RS, Reiss CS, Burakoff SJ, Fiers W, Ault KA: Ia expression by vascular endothelium is inducible by activated $T$ cells and by human $\gamma$-interferon. $J$ Exp Med 157: 1339, 1983.

139. DiCorleto PE, de la Motte CA: Characterization of the adhesion of the human monocytic cell line U937 to cultured endothelial cells. J Clin Invest 75: 1153, 1985.

140. Johnston GI, Cook RG, McEver RP: Cloning of GMP-140, a granule membrane protein of platelets and endothelium: Sequence similarity to proteins involved in cell adhesion and inflammation. Cell 56: $1033,1989$.

141. Geng J-G, Bevilacqua MP, Moore KL, McIntyre TM, Prescott SM, Kim JM, Bliss GA, Zimmerman GA, McEver RP: Rapid neutophil adhesion to activated endothelium mediated by GMP-140. Nature 343: 757, 1990.

142. McEver RP, Martin MN: A monoclonal antibody to a membrane glycoprotein binds only to activated platelets. J Biol Chem 259: 9799, 1984.

143. Johnston GI, Kurosky A, McEver RP: Structural and biosynthetic studies of the granule membrane protein, GMP-140, from human platelets and endothelial cells. J Biol Chem 264: 1816, 1989.

144. McEver RP, Beckstead JH, Moore KL, Marshall-Carlson L, Bainton DF: GMP-140, a platelet membrane protein, is also synthesized by vascular endothelial cells and is localized in the Weibelpalade bodies. J Clin Invest 84: 92, 1989.

145. Hattori R, Hamilton KK, Fugate RD, McEver RP, Sims PJ: Stimulated secretion of endothelial von Willebrand factor is accompanied by rapid redistribution to the cell surface of intracellular granule membrane protein GMP-140. J Biol Chem 264: 7768, 1989.

146. Prescott SM, Zimmerman GA, McIntyre TM: Human endothelial cells in culture produce plateletactivating factor (1-alkyl-2-acetyl-sn-glycero-3-phosphocholine) when stimulated with thrombin. Proc Natl Acad Sci USA 81: 3534, 1984. 
147. Whatley RE, Nelson P, Zimmerman GA, Stevens DL, Parker CJ, McIntyre TM, Prescott SM: The regulation of platelet-activating factor production in endothelial cells. The role of calcium and protein kinase C. J Biol Chem 264: 6325, 1989.

148. Wallis WJ, Harlan JM: Effector functions of endothelium in inflammatory and immunologic reactions. Pathol Immunopathol Res 5: 73, 1986.

149. Hanahan DJ: Platelet-activating factor: A biologically-active phosphoglyceride. Annu Rev Biochem 55: $483,1986$.

150. Hwang SB: Identification of a second putative receptor of platelet-activating factor from human polymorphonuclear leukocytes. J Biol Chem 263: 3225, 1988.

151. Zimmerman GA, McIntyre TM, Mehra M, Prescott SM: Endothelial cell-associated plateletactivating factor: A novel mechanism for signaling intercellular adhesion. J Cell Biol 110: 529, 1990.

152. Locksley RM, Heinzel FP, Shepard HM, Agosti J, Eessula TE, Aggarwal BB, Harlan JM: Tumor necrosis factors $\alpha$ nd $\beta$ differ in their capacities to generate interleukin 1 release from human endothelial cells. J Immunol 139: 1891, 1987.

153. Miossec $P$, Ziff $M$ : Immune interferon enhances the production of interleukin 1 by human endothelial cells stimulated with lipopolysaccharide. J Immunol 137: 2848, 1986.

154. Miossec P, Cavender D, Ziff M: Production of interleukin 1 by human endothelial cells. J Immunol 136: $2486,1986$.

155. Libby P, Ordovas JM, Birinyi LK, Auger KR, Dinarello CA: Inducible interleukin-1 gene expression in human vascular smooth muscle cells. J Clin Invest 78: 1432, 1986.

156. Mantovani A, Dejana E: Cytokines as communication signals between leukocytes and endothelial cells. Immunol Today 10: 370, 1989.

157. Zuckerman SH, Shellhaas J, Butler LD: Differential regulation of lipopolysaccharide-induced interleukin-1 and tumor necrosis factor synthesis: Effects of endogenous and exogenous glucocorticoids and the role of the pituitary-adrenal axis. Eur J Immunol 19: 301, 1989.

158. Dejana E, Breviario F, Balconi G, Rossi V, Remuzzi G, de Gaetano G, Mantovani A: Stimulation of prostacyclin synthesis in vascular cells by mononuclear cell products. Blood 64: 1280, 1984.

159. Rossi V, Breviario F, Ghezzi P, Dejana E, Mantovina A: Prostacyclin synthesis induced in vascular cells by interleukin-1. Science 229: 174, 1985.

160. Bevilacqua MP, Pober JS, Majeau GR, Cotran RS, Gimbrone MA Jr: Interleukin-1 (IL-1) induces biosynthesis and cell surface expression of procoagulant activity in human vascular endothelial cells. J Exp Med 160: 618, 1984.

161. Nawroth PP, Handley DA, Esmon CT, Stern DM: Interleukin I produces endothelial cell procoagulant while suppressing cell-surface anticoagulant activity. Proc Natl Acad Sci USA 83: $3460,1986$.

162. Bevilacqua MP, Schleef RR, Gimbrone MA Jr, Loskutoff DJ: Regulation of the fibrinolytic system of cultured human vascular endothelium by interleukin 1. J Clin Invest 78: 587, 1986.

163. Nachman RL, Hajjar KA, Silverstein RL, Dinarello CA: Interleukin 1 induces endothelial cell synthesis of plasminogen activator inhibitor. J Exp Med 163: 1595, 1986.

164. Bussolino F, Breviario F, Tetta C, Aglietta M, Mantovani A, Dejana E: Interleukin 1 stimulates platelet-activating factor production in cultured human endothelial cells. J Clin Invest 77:2027, 1986.

165. Sayers TJ, Wiltrout TA, Bull CA, Denn III AC, Pilaro AM, Lokesh B: Effect of cytokines on polymorphonuclear neutrophil infiltration in the mouse. Prostaglandin- and leukotriene-independent induction of infiltration by IL-1 and tumor necrosis factor. J Immunol 141: 1670, 1988.

166. Broudy VC, Kaushansky K, Harlan JM, Adamson JW: Interleukin 1 stimulates human endothelial cells to produce granulocyte-macrophage colony-stimulating factor and granulocyle colonystimulating factor. J Immunol 139: 464, 1987.

167. Sieff CA, Niemeyer CM, Mentzer SJ, Faller DV: Interleukin-1, tumor necrosis factor, and the production of colony-stimulating factors by cultured mesenchymal cells. Blood 72: 1316, 1988.

168. Wang JM, Chen ZG, Cianciolo GJ, Snyderman R, Breviario F, Dejana E, Mantovani A: Production of a retroviral P15E-related chemotaxis inhibitor by IL-I treated endothelial cells. A possible 
negative feedback in the regulation of the vascular response to monokines. J Immunol 142: 2012, 1989.

169. Sironi M, Breviario F, Proserpio P, Biondi A, Vecchi A, Van Damme J, Dejana E, Mantovani A: IL-1 stimulates IL-6 production in endothelial cells. J Immunol 142: 549, 1989.

170. Raines EW, Dower SK, Ross R: Interleukin-1 mitogenic activity for fibroblasts and smooth muscle cells is due to PDGF-AA. Science 243: 393, 1989.

171. Libby P, Wyler DJ, Janicka MW, Dinarello CA: Differential effects of human interleukin-1 on growth of human fibroblasts and vascular smooth muscle cells. Arteriosclerosis 5: 186, 1985.

172. Libby P, Warner SJC, Friedman GB: Interleukin 1: a mitogen for human smooth muscle cells that induces the release of growth-inhibitory prostanoids. J Clin Invest 81: 487, 1988.

173. Gamble JR, Harlan JM, KlebanoffSJ, Vadas MA: Stimulation of the adherence of neutrophils to umbilical vein endothelium by human recombinant tumor necrosis factor. Proc Natl Acad Sci USA 82: 8667, 1985.

174. Nawroth P, Handley J, Cassimexis J, Chess L, Stern D. Tumor necrosis factor/cachectin interacts with endothelial cell receptors to induce release of interleukin 1. J Exp Med 163: 1363, 1986.

175. Kawakami M, Ishibashi S, Ogawa H, Murase T, Takaku F, Shibata S: Cachectin/TNF as well as interleukin-1 induces prostacyclin synthesis in cultured vascular endothelial cells. Biochem Biophys Res Commun 141: 482, 1986.

176. Bevilacqua MP, Pober JS, Majeau GR, Fiers W, Cotran RS, Gimbrone MA Jr: Recombinant tumor necrosis factor induces procoagulant in human vascular endothelium: Characterization and comparison with the actions of interleukin 1. Proc NAtl Acad Sci USA 83: 4533, 1986.

177. Van Hinsbergh VWM, Kooistra T, van den Berg EA, Princen HMG, Fiers W, Eneis JJ: Tumor necrosis factor increases the production of plasminogen activator inhibitor in human endothelial cells in vitro and in rats in vivo. Blood 72: 1467, 1988.

178. Camussi G, Bussolino F, Salvidio G, Baglioni C: Tumor necrosis factor/cachectin stimulates peritoneal macrophages, polymorphonuclear neutrophils, and vascular endothelial cells to synthesize and release platelet activating factor. J Exp Med 166: 1390, 1987.

179. Pober JS, Lapierre LA, Stolpen A, Brock TA, Springer TA, Fiers W, Bevilacqua MP, Mendrick DL, Gimbrone MA Jr: Activation of cultured endothelial cells by recombinant lymphotoxin: Comparison with tumor necrosis factor and interleukin 1 species. J Immunol 138:3319, 1987.

180. Einhorn S, Eldor A, Vlodavsky I, Fuks ZVI, Panet A: Production and characterization of interferon from endothelial cells. J Cell Physiol 122: 200, 1985.

181. Van Damme, Schaafsma MR, Fibbe WE, Falkenburg JHF, Opdenakker G, Billiau A: Simultaneous production of interleukin 6 , interferon- $\beta$ and colony-stimulating avtivity by fibroblast after viral and bacterial infection. Eur J Immunol 19: 163, 1989.

182. Billiau A: In: Monokines and other non-lymphocytic cytokines (Powanda MC, Oppenheim JJ, Kluger MJ, Dinarello CA, eds) pp 3-13, Alan Liss, 1988.

183. Quesenberry PJ, Gimbrone MA Jr: Vascular endothelium as a regulator of granulopoiesis: Production of colony stimulating activity by cultured human endothelial cells. Blond 56: 1060, 1980.

184. Gerson SL, Friedman HM, Cines DB: Viral infection of vascular endothelial cells alters production of colony-stimulating activity. J Clin Invest 76: 1382, 1985.

185. Bussolino F, Wang JM, Defilippi P. Turrini F, Sanavio F. Edgell C-JS, Aglietta M, Arese P, Mantovani A: Granulocyte- and Granulocyte-macrophage-colony stimulating factors induce human endothelial cells to migrate and proliferate. Nature 337: 471, 1989.

186. Wang JM, Colella S, Allavena P, Mantovani A: Chemotactic activity of human recombinant granulocyte-macrophage colony-stimulating factor. Immunology 60: 439, 1987.

187. Wang JM, Chen ZG, Colella S, Bonilla MA, Welte K, Bordignon C, Mantovani A: Chemotactic activity of recombinant human granulocyte colony-stimulating factor. Blood 72: 1456, 1988.

188. Yoshimura T, Matsushima K, Tanaka S, Robinson EA, Appella E, Oppenheim J, Leonard EJ: Purification of a human monocyte-derived neutrophil chemotactic factor that has peptide sequence similarity to other defense cytokines. Proc Natl Acad Sci USA 84: 9233, 1987.

189. Djeu JY, Oppenheim JJ, Shiotsuki K, Blanchard DK: Functional activation of human neutrophils by recombinant monocyte-derived neutrophil chemotactic factor/IL-8. J Immunol 144: 2205, 1990. 
190. Gimbrone MA Jr, Obin MS, Brock AF, Luis EA, Hass PE, Hebert CA, Yip YK, Leung DW, Kohr WJ, Darbonne WC, Bechtol KB, Baker JB: Endothelial interleukin-8: A novel inhibitor of leukocyte-endothelial interactions. Science 246: 1601, 1989.

191. Matsushima K, Oppenheim JJ: Interleukin-8 and MCAF: Novel inflammatory cytokines inducible by IL-1 and TNF. Cytokine 1: 2, 1989.

192. Sica A, Matsushima K, Van Damme J, Wang JM, Polentarutti N, Dejana E, ColottaF, Mantovani A: Il-1 transcriptionally activates the neutrophil chemotactic factor/ IL-8 gene in endothelial cells. Immunology 69: 548, 1990.

193. Wheeler ME, Luscinskas FW, Bevilacqua MP, Gimbrone MA Jr: Cultured human endothelial cells stimulated with cytokines or endotoxin produce an inhibitor of leukocyte adhesion. J Clin Invest 82: $1211,1988$.

194. Collins T, Korman AJ, Wake CT, Boss JM, Kappes DJ, Fiers W, Ault KA, Gimbrone MA, Strominger JL, Pober JS: Immune interferon activates multiple class II major histocompatibility complex genes and the associated invariant chain gene in human endothelial cells and dermal fibroblasts. Proc Natl Acad Sci USA 81: 4917, 1984.

195. Friesel R, Komoriya A, Maciag T: Inhibition of endothelial cell proliferation by gamma-interferon. J Cell Biol 104: 698, 1987.

196. Nathan CF: Secretory products of macrophages. J Clin Invest 79: 319, 1987.

197. Müller G, Behrens J, Nussbaumer U, Böhlen P, Birchmeier W: Inhibitory action of transforming growth factor $B$ on endothelial cells. Proc Natl Acad Sci USA 84: 5600, 1987.

198. Takehara K, LeRoy EC, Grotendorst GR: TGF-B inhibition of endothelial cell proliferation: Alteration of EGF binding and EGF-induced growth-regulatory (competence) gene expression. Cell 49: $415,1987$.

199. Madri JA, Pratt BM, Tucker AM: Phenotypic modulation of endothelial cells by transforming growth factor- $\beta$ depends upon the composition and organization of the extracellular matrix. I Cell Biol 106: 1375, 1988.

200. Mignatti P, Tsuboi R, Robbins E, Rifkin DB: In vitro angiogenesis on the human amniotic membrane: Requirement for basic fibroblast growth factor-induced proteinase. J Cell Biol 108: 671, 1989.

201. Gamble JR, Vadas MA: Endothelial adhesiveness for blood neutrophils is inhibited by transforming factor-ß. Science 242: 97, 1988. 
CHAPTER III

CMV INDUCES VASCULAR INJURY IN THE RAT: A MODEL FOR THE STUDY OF EARLY ATHEROSCLEROTIC LESIONS

* Span AHM, Grauls G, Bosman F, van Boven CPA, Bruggeman CA. Submitted for publication. 


\section{ABSTRACT}

The role of cytomegalovirus (CMV) in the early development of atherosclerosis was studied in a rat model. Arterial samples derived from virus infected normo- and hypercholesterolemic animals were investigated by light microscopy at $1,4,8$, and 16 weeks post infection. The CMV infected hypercholesterolemic rats were sampled at the same time which corresponded with $8,11,15$, and 23 wexks of cholesterol diet. Early atherogenic lesions comparable to those seen in noninfected hypercholesterolemic rats were found in CMVinfected normocholesterolemic and hypercholesterolemic animals, consisting of minimal endothelial cell damage, an increase in the number of leukocytes adhering to the aortic intima, presence of lipophages and accumulation of lipids in the endothelium. Our results support the hypothesis that CMV may be one of the factors involved in atherogenesis. 


\subsection{INTRODUCTION}

The possibility that viral infection plays a role in the pathogenesis of atherosclerosis is supported by Fabricant's observations in chickens infected with a herpesvirus, the Marek's disease virus (MDV)(1-4). She and her colleagues showed that lesions, closely resembling the chronic human arteriopathy, were reproducibly induced in the chickens by MDV infection. The lesions were characterized by intimal cell proliferation, lipid accumulation, and connective tissue deposition.

In humans the role of herpesvirus in the etiology of atherosclerosis is substantiated by the following studies. Melnick et al. (5) demonstrated cytomegalovirus (CMV) antigens within arterial smooth muscle cells. Gyorkey et al. (6) reported the presence of herpes virions in artcrial cells from atherosclerotic patients, while Adam et al. (7) found higher levels of CMV antibody more frequently in patients requiring vascular surgery than in trauma victims. Furthermore, Hendrix et al. (8) detected CMV in human arterial specimens by in situ DNA hybridization techniques. By using the polymerase chain reaction he found that the prevalence of CMV nucleic acids was significantly higher in patients suffering from severe atherosclerosis than in paticnts with maximally grade I atherosclerosis (9).

One of the current hypotheses regarding the induction of atherosclerosis is the response to injury concept formulated by Ross and Glomset (10). Recently, Ross revised his response to injury hypothesis and postulated two pathogenctic pathways (11). The first pathway has becn observed in experimentally induced hypercholesterolemia. The second pathway involves direct stimulation of endothelium, which may be injured but remains intact, and which releases growth factors that induce proliferation and migration of smooth muscle cells. Mozar et al. (12) recently suggested that viruses might be involved in the latter pathway. In this view atherosclerosis is an inflammatory process that can be initiated by suitable viruses or other endothelium damaging agents and aggrevated by hypercholesterolemia and other recognized risk factors.

The availability of a rat CMV provided us the opportunity to investigate the relation between virus infection and atherosclerosis in rat. For this purpose rats were infected with CMV and at several intervals post infection the aortas were examined by light microscopy. In this paper the effects of CMV infection on plasma lipid distribution, adhesion of leukocytes to endothelial cells, damage of the endothelium, lipid deposition in the arterial intima and formation of lipophages are described. In order to obtain a reference point for evaluating the alterations found in virus-infected rats we used a control group of rats which were fed a cholesterol-diet as described (13).

\subsection{MATERIALS AND METHODS}

\subsubsection{Rats}

Wistar rats were bred under specific pathogen free (SPF) conditions at the Department of Experimental Animal Services, University of Limburg Biomedical Center, Maastricht, The Netherlands. The animals were free of CMV and all other known viral and microbial pathogens (14). 


\subsubsection{Virus stock}

The rat cytomegalovirus (CMV) used in this study was isolated in our laboratory (15). To maintain the virus stock, salivary gland suspensions were passaged intraperitoneally in three to four weeks old Brown Norway rats as described previously (16). Briefly, virus was harvested three weeks after the inoculation, by homogenizing the salivary glands in a tissue grinder. These homogenates, $10 \%(w / v)$ in Eagles Minimal Essential Medium, were stored at $-80^{\circ} \mathrm{C}$ until use.

DESICE OF FXPERIMEN
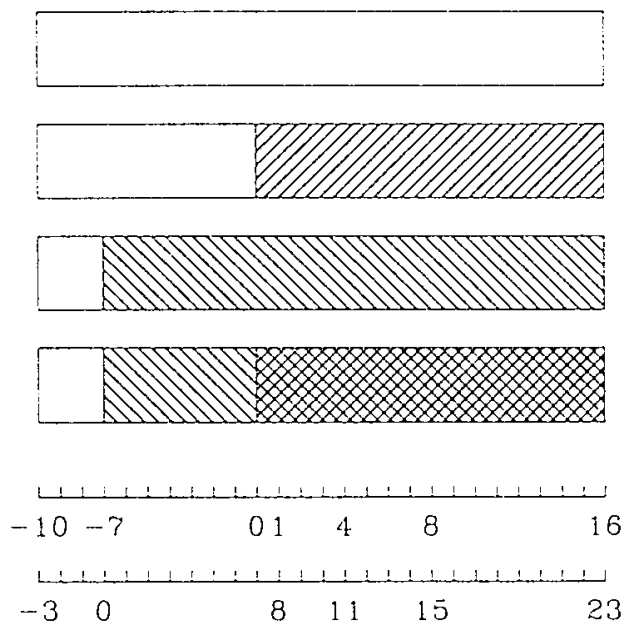

ZZA :X:ET:

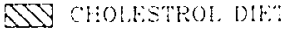

Standard chow dud Vonntected

Stanciard chow diet lnotert

Cholesterol inet Somntorted

Cholesteroi dietinfected

WHEHS POST MNECTON

"WEBS OF CHOLESTROL DIE?

fig. 1: Design of experiment. Initially all rats were fed a standard diet (normocholesterolemic rats). 3 weeks later, half of the rats started with a high cholesterol diet (hypercholesterolemic rats). At the age of 10 weeks half of the normocholesterolemic and hypercholesterolemic rats were infected with CMV. The infected rats were sampled at week $1,4,8$, and 16 p.i. Hypercholesterolemic rats were sampled at the same times, corresponding with $8,11,15$, and 23 weeks of cholesterol diet.

\subsubsection{Experimental groups}

Four comparably sized groups $(n=25)$ were randomly selected from the SPF stock. All rats, weighing 200-225 gram were initially fed a standard chow diet (Hopefarms, Woerden, The Netherlands) relatively low in cholesterol (less than $0.02 \%$ cholesterol). At the age of 3 weeks fifty rats started with the standard diet supplemented with $4 \%$ 
cholesterol (w/v), $1 \%$ cholic acid and $0.5 \% 2$-thiouracil. At the age of 10 weeks fifty rats, 25 rats fed with the standard diet and 25 rats fed with the cholesterol diet, were inoculated intravenously with $4 \times 10^{5}$ plaque forming units (PFU) CMV per rat. Infected rats and the remaining uninfected rats were housed in separate cages during the entire experiment. During the whole experiment the animals were weighed every 2 weeks. At week 1, 4, 8 and 16 post infection (p.i.) eight rats were randomly selected from each group and autopsied. Uninfected rats were sampled at the same times, corresponding with $8,11,15$, and 23 weeks of cholesterol diet (fig.1).

\subsubsection{Blood lipid studies}

The rats were fasted overnight prior to taking blood specimens, which were also taken prior to autopsy. Blood was collected $(1.5 \mathrm{ml})$ in test tubes and centrifuged $(10 \mathrm{~min}, 1800$ rpm). The sera were tested for total cholesterol, high density lipoproteins (HDLcholesterol), low density lipoproteins (LDL-cholesterol) and triglycerides by a Cobas Bio centrifugal analyzer with results expressed as $\mathrm{mmol} / \mathrm{l}$ (dept. of Clinical chemistry [Prof. P.J. Brombacher], Hospital de Wever, Heerlen, The Netherlands).

\subsubsection{Light microscopy}

For histochemical studies at light microscopic level, samples of the thoracic-abdominal aortas were excised. The aorta was prepared for study en face (13) as follows. At the given intervals p.i. rats were killed by ether inhalation and exsanguinated. A thoracotomy was performed, the left atrium was cannulated with a 21-gauge injection needle, and solutions were infused at $110 \mathrm{~mm} \mathrm{Hg}$ in the following sequence: sterile salt-solution: $0.9 \%$ $\mathrm{NaCl}$ (in phosphate buffer, $\mathrm{pH} 7.4 ; 7 \mathrm{~min}), 2.5 \%$ glutaraldehyde $(10 \mathrm{~min}), 0.05 \%$ silver solution $\left(\mathrm{AgNO}_{3}, 1 \mathrm{~min}\right)$ and bromides $\left(3 \% \mathrm{CoBr}, 1 \% \mathrm{NH}_{4} \mathrm{Br} ; 1 \mathrm{~min}\right)$. The vena cava was used as outlet. The thoracic aorta was excised, immersed in fixative, exposed under a desk lamp with a 60 watt bulb (total fixation $3 \mathrm{hrs}$ ), transferred to cacodylate buffer $(0.1 \mathrm{M}, \mathrm{pH}$ 7.4) and refrigerated at $4{ }^{\circ} \mathrm{C}$ overnight. The next morning the vessel was dissected free of periadventitial tissue, rinsed in distilled water $(1 \mathrm{~min})$, immersed in $70 \%$ isopropyl alcohol $(10 \mathrm{~min})$, stained with oil red $\mathrm{O}(\mathrm{ORO} ; 10 \mathrm{~min}$ [by injection into the lumen]), rinsed again in distilled water, stained with filtered Harris' hematoxylin $(45 \mathrm{sec})$, and washed again in distilled water. The aorta was cut into segments $5-8 \mathrm{~mm}$ long. These segments were opened with iridectomy scissors and mounted flat in glycerine jelly (endothelium faced up). Segments were selected at randomly for en face examination; $50 \mathrm{~mm}^{2}$, i.e. $1 / 4$ th of the aorta per animal was investigated at a $\times 400$ magnification. The total surface of the aortic sample was observed and the number of adhering leukocytes was counted. In addition, the area with ORO positive endothelial cells was measured. The adhesion is expressed as the number of leukocytes present on the examined sample area. The area containing the ORO stain, i.e. endothelial cells filled with ORO droplets, is expressed as percentage of the total investigated sample area. 


\subsubsection{Statistical analysis}

For comparison of serum cholesterol, HDL-, LDL- cholesterol and triglycerides between the groups, statistical significance was calculated using the 2-tailed student t-test. The 2tailed Wilcoxon ranked score test was used to analyze significance of difference in adhesion between the virus infected- and noninfected normocholesterolemic rats and between virus infected- and noninfected hypercholesterolemic rats.
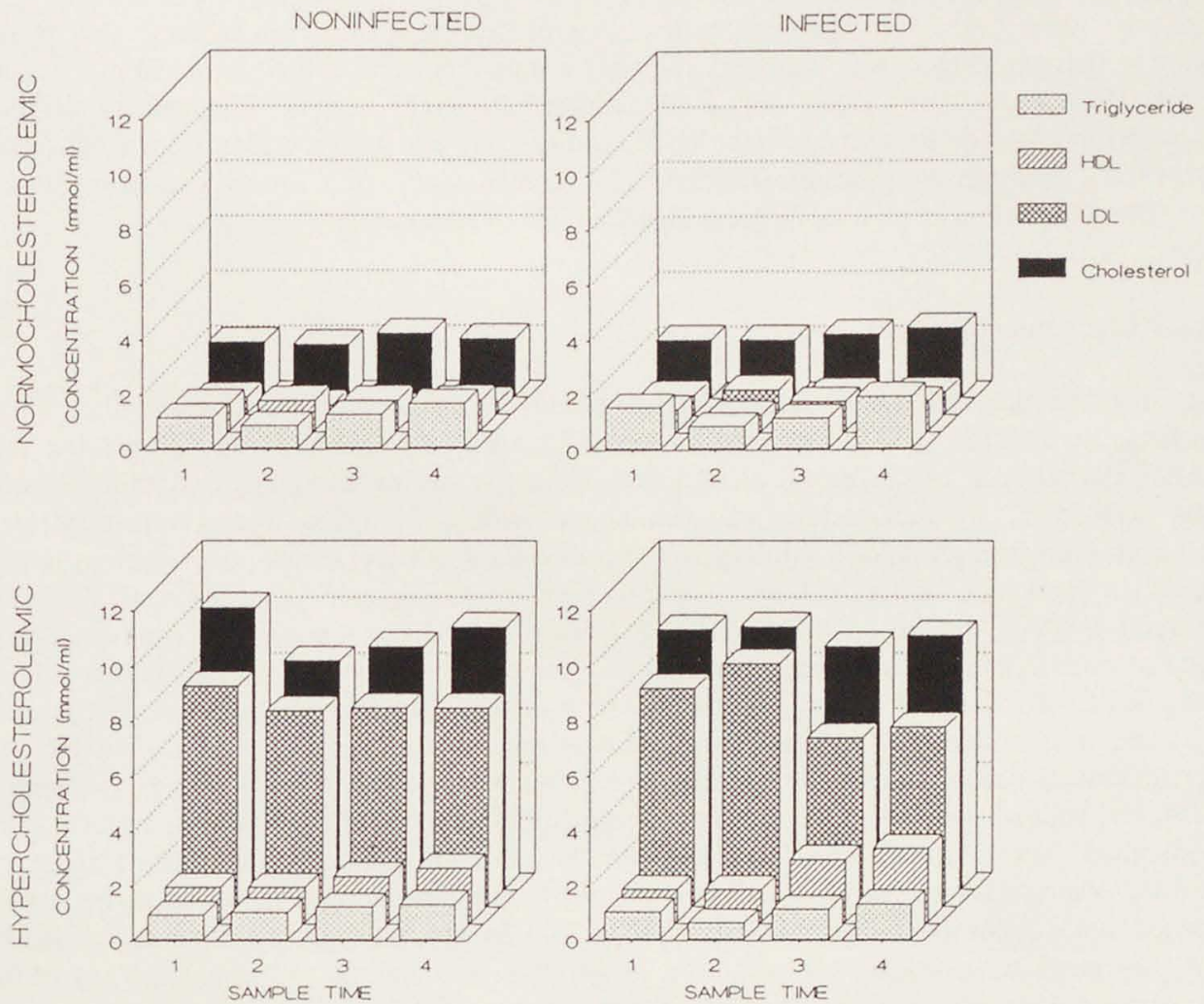

fig. 2: Plasma cholesterol, LDL, HDL, and triglycerides values (mean \pm SEM) and their changes with time in the experimental rats. The differences in cholesterol or LDL values between the hypercholesterolemic rats and the normocholesterolemic rats were highly significant $(* *$ : $p<0.001)$. The differences in HDL or triglyceride values between those rats were not significant $(\mathrm{p}>0.05)$. 


\subsection{RESULTS}

\subsubsection{Weight}

Control rats and virus infected rats on standard diet gained weight steadily. In contrast, rats on the cholesterol-thiouracil diet gained little or no weight, due to the fact that this diet is a thyroid-suppressive diet (14).

\subsubsection{Plasma lipids}

In fig. 2 the concentrations of total cholesterol, LDL, HDL and triglycerides in the plasma samples of the four different groups are shown. Within the groups the values did not change significantly during the entire experiment $(\mathrm{p}>0.05)$.

In noninfected normocholesterolemic rats, cholesterol, LDL- and HDL-cholesterol remained at levels of respectively $2.1 \pm 0.3 \mathrm{mmol} / \mathrm{l}, 0.4 \pm 0.2$ and $1.0 \pm 0.2 \mathrm{mmol} / \mathrm{l}$ (mean \pm SEM) (fig.2a).

In the virus infected normocholesterolemic rats similar cholesterol, HDL and LDL values were found (fig.2b).

In the hypercholesterolemic rats, cholesterolemia was clearly present at the first sample time and thereafter (fig.2c). The cholesterol level showed a five fold increase (10.2 \pm 0.5 ) as compared to the level observed in normocholesterolemic rats. LDL-cholesterol level showed a ten-fold increase $(8.0 \pm 0.5)$, while the HDL-cholesterol value and the triglyceride fraction did not increase at that time (respectively $1.3 \pm 0.4$ and $0.9 \pm 0.2$ ). The differences observed in cholesterol and LDL values obtained from normocholesterolemic- and hypercholesterolemic-rats were highly significant $(\mathrm{p}<0.001)$.

CMV infection of the hypercholesterolemic rats had either effect on the cholesterol level in the plasma, nor on HDL-cholesterol and LDL-cholesterol levels (fig.2d).

Thus in both normocholesterolemic and hypercholesterolemic rats CMV infection did not affect the plasma lipid levels.

\subsubsection{Light microscopy}

\section{Qualitative Studies}

Silver impregnated aortas derived from all four groups showed no macroscopic aortic lesions at the four sample times. Microscopic investigation of the silver impregnated aortas derived from noninfected normocholesterolemic rats showed an intact endothelium. The endothelial cell boundaries stained black, while the surface of these cells showed no or very light staining (fig.3a). The few adherent leukocytes stood out clearly against the background of the endothelium. These adherent cells were usually single and widely scattered (fig.3b). Sometimes it seemed that a leukocyte passes between the endothelial cells, as shown by a thick silver staining around this cell, presumably caused by the presence of different cell boundaries (fig.3b). Preparations of noninfected normocholesterolemic rats stained with ORO showed no staining of the endothelium: the endothelial cells were free of fat droplets; lipophages i.e. leukocytes loaded with fat 

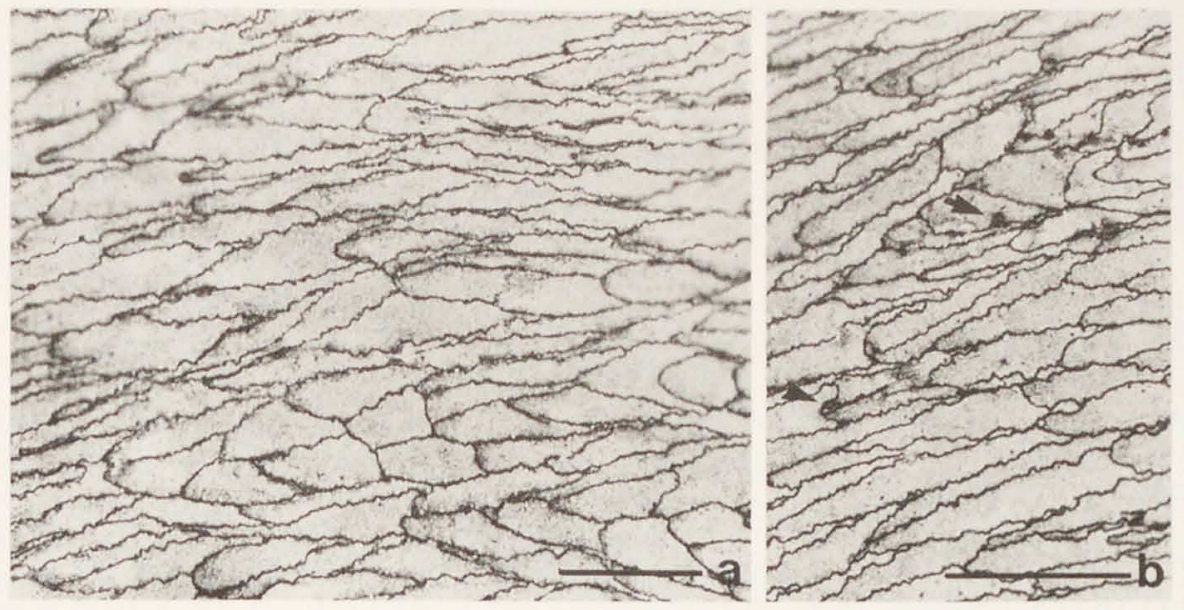

fig.3: Noninfected normocholesterolemic rat. Aortic intima viewed en face after staining with silvernitrate and oil red $\mathrm{O}$ shows an intact endothelium; a single leukocyte is attached (arrow) to the intima. A migrating leukocyte is present in this preparation (arrow head). Bar represents $50 \mu \mathrm{m}$.

droplets, were also not observed.

Microscopic investigation of CMV infected normocholesterolemic rats showed also an intact endothelium. However, in contrast to noninfected normocholesterolemic rats, a few endothelial cells with an intensive surface silver nitrate staining were observed. The number of these cells was very low and they were gathered in clusters (fig.4a).

Further, CMV infection of the normocholesterolemic rats resulted in a different pattern of leukocyte adhesion and in a different distribution of ORO containing cells. The aortic endothelium of infected normocholesterolemic rats showed more leukocytes adhering to the endothelium. These leukocytes were not single and randomly distributed but were gathered in clusters (fig.4b). The adhesion of leukocytes was focal. Some clusters were located around the ostium of an arterial branch (fig.4c), others appeared in a seemingly random distribution on the aortic intima (fig.4b). Fig.4d shows a common observation, namely a dense cluster of cells attached to the margins and body of a single endothelial cell. Seldomly subendothelial cells, which could be migrated leukocytes, were seen. These cells were characterized by a slightly elongated pale grey nucleus which distinguished them from endothelial cells and from surface attached cells (fig.4e). Often red blood cells were present between the adherent leukocytes or in clusters which were randomly spread on the aortic intima (fig.4f); this phenomenon was constant during the period of investigation. In the intima of the aorta derived from CMV infected normocholesterolemic rats lipid deposition was present. Preparations showed fat droplets in the endothelial cells at week 1 p.i. (fig. $4 \mathrm{~g}$ ); the ORO positive endothelial cells were irregularly distributed on the luminal surface and their number slightly increased during the experimental time course. 
Furthermore, lipophages were seen on the luminal surface of the endothelium in specimens obtained at 8 and 16 weeks post infection (fig.4h).

Noninfected rats fed a cholesterolemic diet also showed an intact endothelium, but again endothelial cells with intensive surface silver staining were observed (fig.5a). Also clusters of leukocytes adherent to the aortic intima were seen. These clusters contained leukocytes which were in general larger and with greater variation in size (fig.5b). In addition, a few leukocytes migrated through the endothelium (fig.5c), and endothelial cells filled with lipid were observed (fig.5d). Thus, similar results as described for CMV infected normocholesterolemic rats were detected. However the degree of the observed changes was higher: the number of endothelial cells containing lipid droplets and the number of adherent leukocytes were higher. Further the amount of lipid per endothelial cell was raised (fig.5d).

In CMV infected hypercholesterolemic rats a similar observation with respect to adhesion was made in comparison with virus infected normocholesterolemic rats. However, when compared to hypercholesterolemic rats less adhesion of leukocytes was observed, although the number of subendothelial cells was higher in CMV infected hypercholesterolemic rats. They became numerous within the preparations of rats sampled at 8 and 16 weeks of infection (fig.5e). More endothelial cells covered with the black silver stain were seen in the aortic samples of virus infected cholesterolemic rats (fig.5e). These cells were most obvious in the neighborhood of arterial branches. 


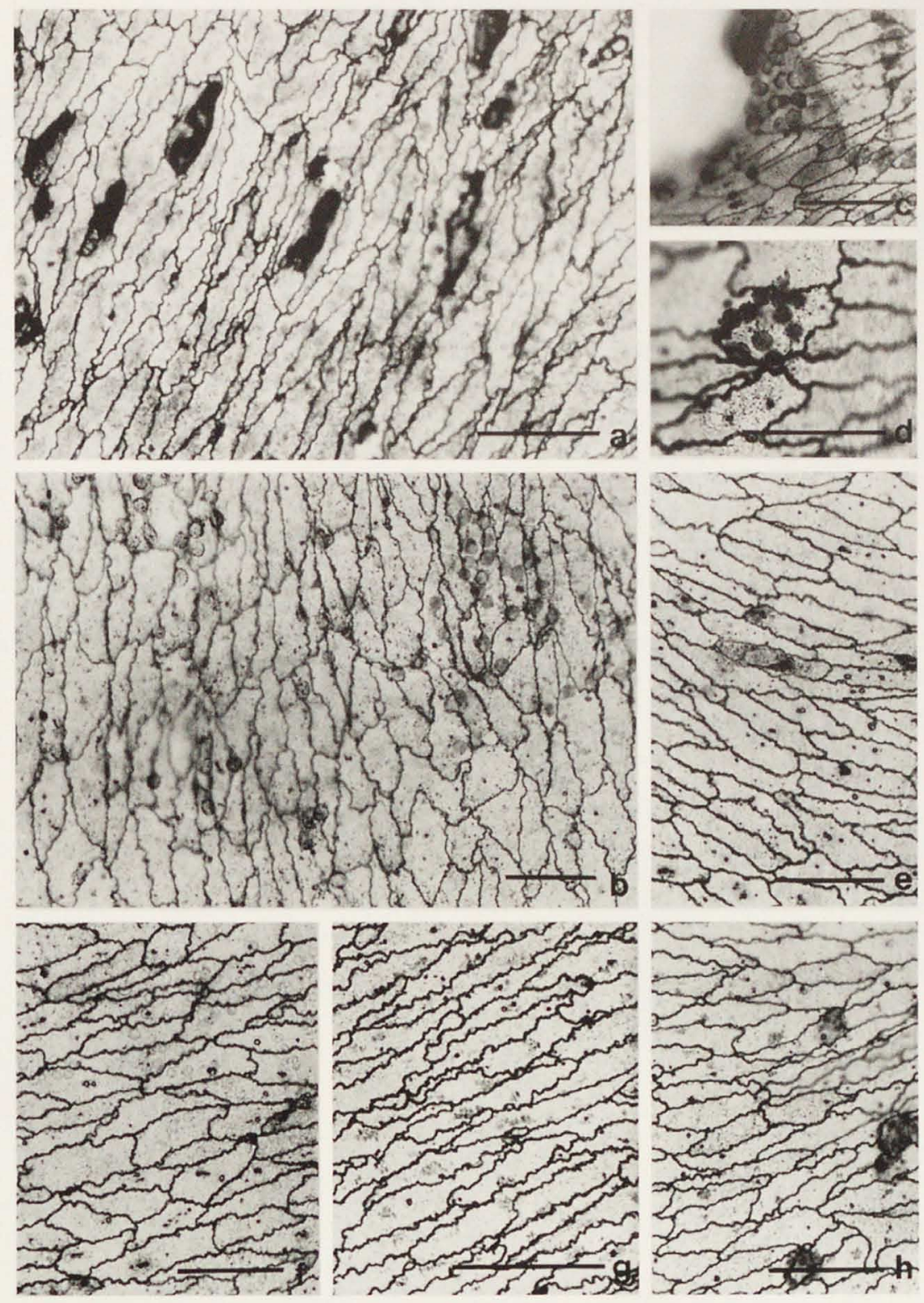

fig.4: Aorta of a normocholesterolemic rat after 1 week of infection. Viewed en face after silver nitrate surface staining and ORO staining. An intact endothelium with a few endothelial cells showing an intensive surface nitrate staining (a) was observed. Clusters of adhering leukocytes are seen randomly on the aortic intima (b), around the ostium of an aortic branche (c), and onto the body and margins of a single endothelial cell (d). A migrated cell is observed (e). Attached red blood cells were visible in the preparation (f). ORO droplets corresponding with the little gray dots were present in the endothelium $(\mathrm{g})$ and in attached cells $(\mathrm{h})$. Bar represents $50 \mu \mathrm{m}$. 


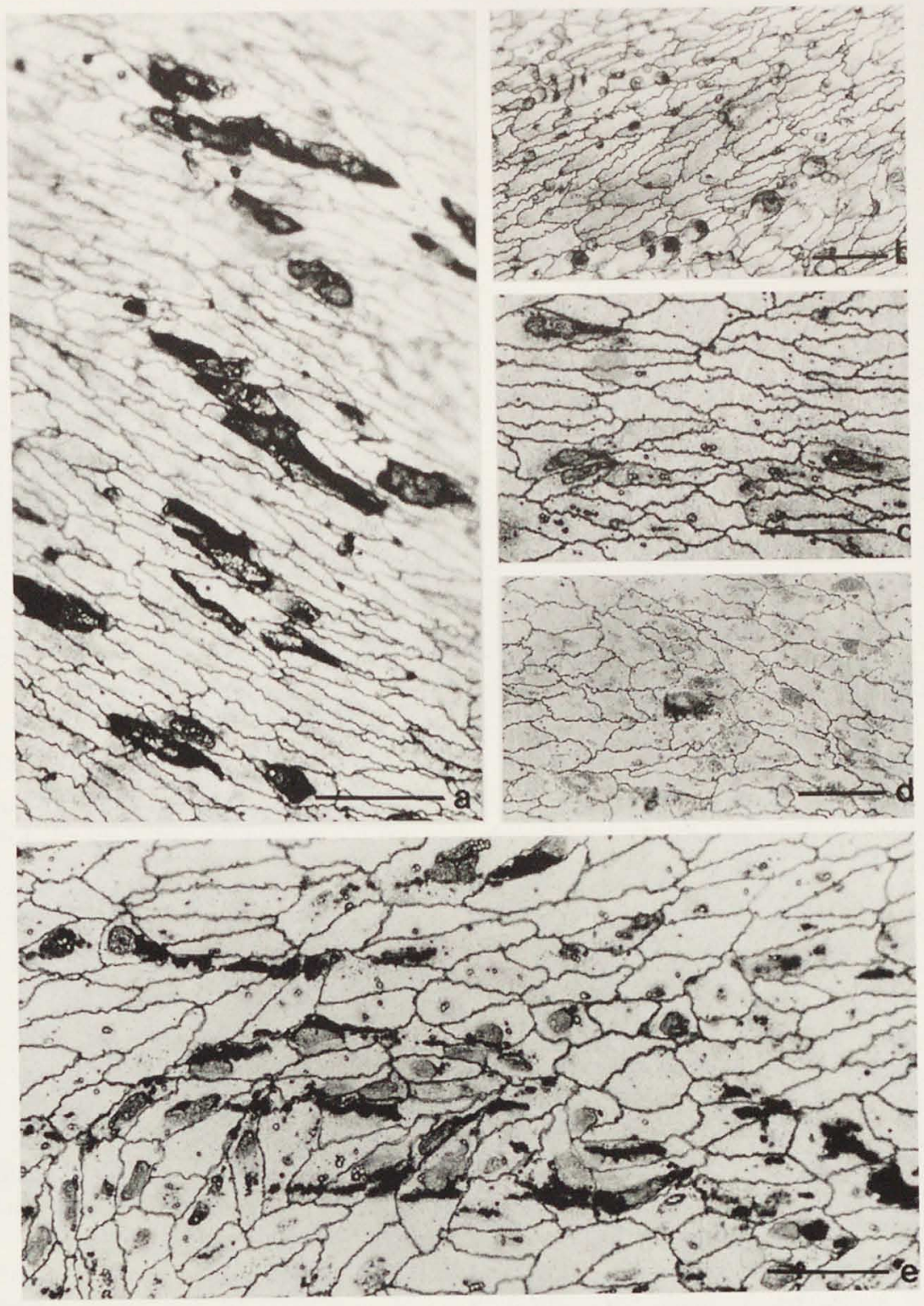

fig.5: Aorta of a rat sampled after 8 weeks of cholesterol diet, viewed en face. An intact endothelium is observed; endothelial cells with an intensive surface nitrate staining (a); clusters of adhering leukocytes (b); subendothelial cells (c); and endothelial cells containing lipid droplets (d) were observed. In the aortic intima of $\mathrm{CMV}$-infected hypercholesterolemic rats sampled at 16 weeks p.i. numerous subendothelial cells and endothelial cells covered with the black silver stain were observed in the neighborhood of an aortic branch (e). Bar represents $50 \mu \mathrm{m}$. 


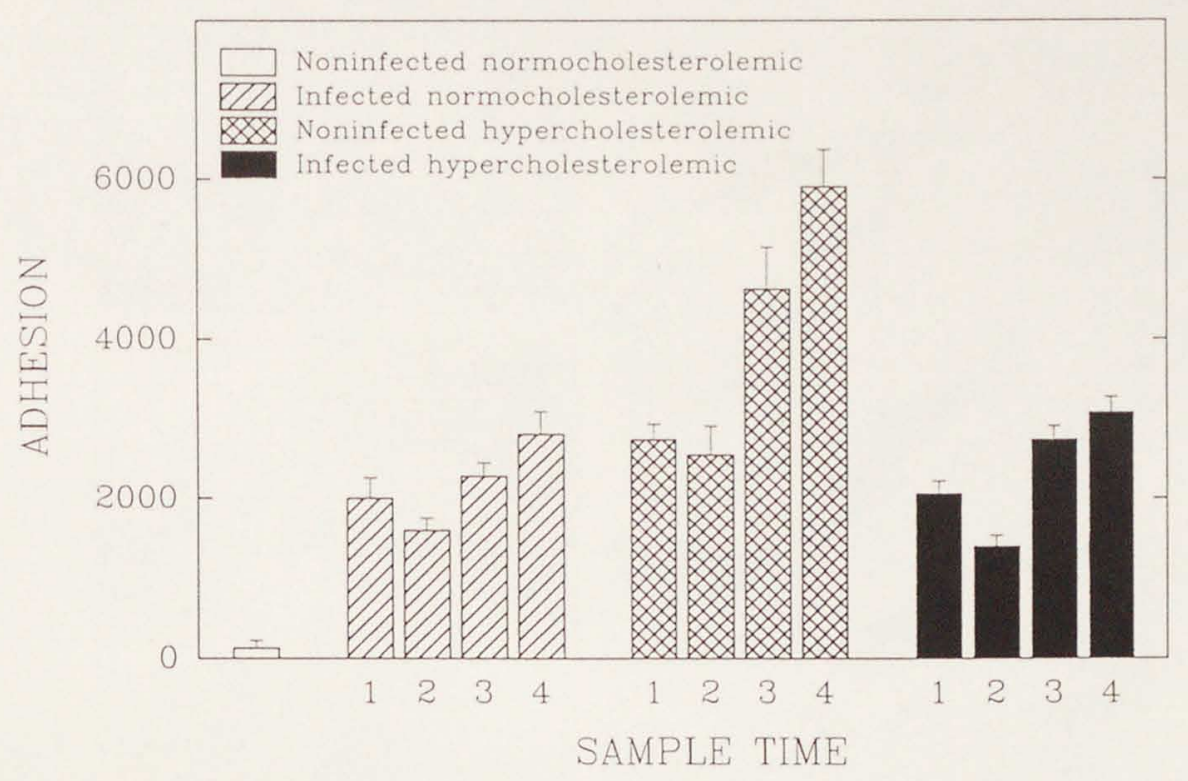

fig.6: Quantification of adherent cells on the aortic intima of infected- or noninfected-normocholesterolemic and hypercholesterolemic rats. Per specimen an area of $50 \mathrm{~mm}^{2}$ is examined; the mean $( \pm$ SEM) of the total number of adherent cells is shown. The sample times used for infected rats correspond with 1, 4, 8, and 16 weeks p.i.; the sample times used for hypercholesterolemic rats correspond with $8,11,15$, and 23 weeks of cholesterol diet. The difference between the untreated and treated experimental rats were highly significant (**: $\mathrm{p}<0.001$ ).

\section{Quantitative studies}

The degree of adhesion to the endothelium of the four groups is shown in Fig.6, and is expressed as the total number of adherent cells present (described in Materials and Methods).

In noninfected normocholesterolemic rats adherent leukocytes were randomly distributed on the luminal surface. The leukocyte adhesion did not change with time; a number of $128 \pm 93$ leukocytes was found at the four sample times (mean \pm SEM).

CMV infected normocholesterolemic rats showed a 16 -fold increase in the number of adherent leukocytes 1 week after infection when compared to the number found in noninfected normocholesterolemic rats. $2002 \pm 260$ adhering leukocytes were measured. The adhesion continued to increase (fig.6) after the second sample time. At week 16 p.i. $2808 \pm 286$ adherent leukocytes were measured.

In noninfected cholesterolemic rats the leukocyte adhesion increased 20 -fold after 8 weeks of cholesterol diet $(2743 \pm 195)$ up to $5904 \pm 468$ after 23 weeks of cholesterol diet. 
CMV infection of the hypercholesterolemic rats did not result in an additional increase of leukocyte adhesion compared to noninfected hypercholesterolemic rats, respectively $2060 \pm 160$ and $2743 \pm 195$ adhering leukocytes were counted at 1 the first sample time (fig.6). However, more clusters of migrated cells were observed under the endothelium, when compared to noninfected cholesterolemic rats (fig. $5 c, e$ ).

Nevertheless, when compared to noninfected normocholesterolemic rats CMV infection of the hypercholesterolemic rats resulted in increased leukocyte adhesion (from $128 \pm 93$ to $2060 \pm 160$, respectively). This increase in adhesion continued after virus infection and during hypercholesterolemia $(3080 \pm 190)$.

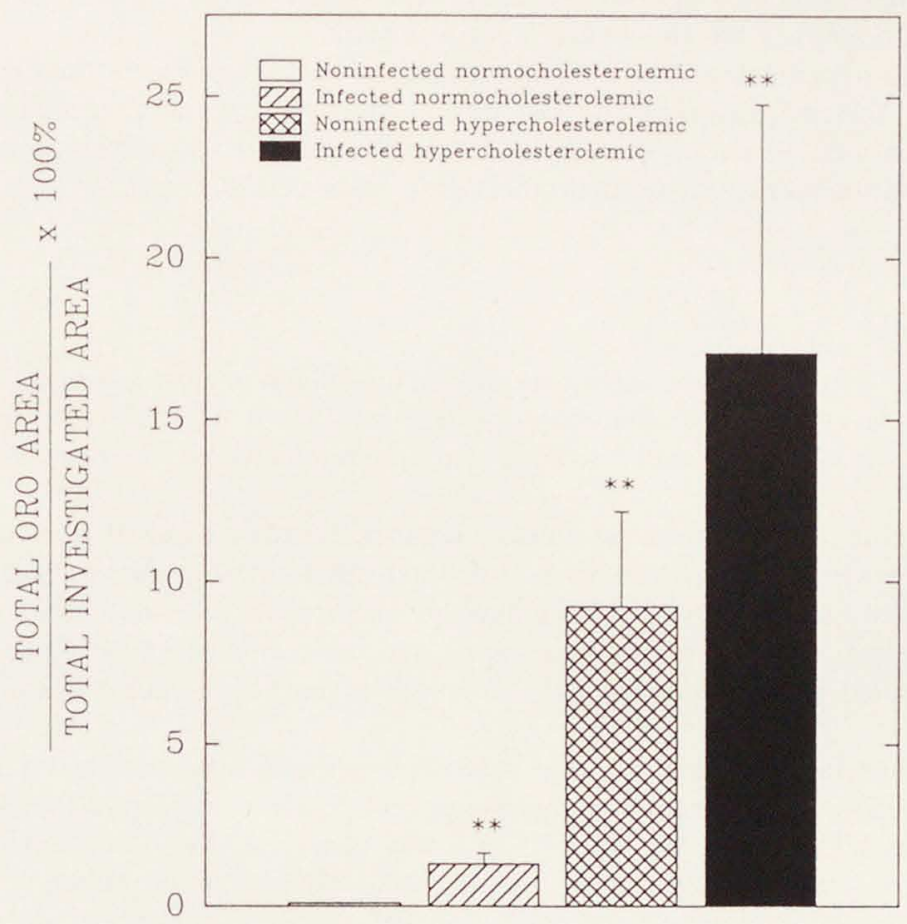

fig.7: Quantification of lipid droplets present in the endothelium derived from infected- or noninfectednormocholesterolemic and hypercholesterolemic rats. The preparations are viewed en face and $50 \mathrm{~mm}^{2}$ of these preparations is examined. The lipid-containing area is expressed as percentage of the total examined area; and it did not change during the experimental time: the mean \pm SEM of the examined areas of the four sample times is shown. The differences between untreated and treated experimental rats were significant (**: $\mathrm{p}<0.001)$.

The total vessel wall area containing lipids, shown in fig.7, is expressed as a percentage of the investigated sample area. 
ORO positive droplets were not found in the samples derived from normocholesterolemic rats.

However, CMV infection of the normocholesterolemic rats induced lipid droplets in the endothelial cell surface, already at the first week after infection. The ORO positive area did not change significantly with time: about $1 \%$ of the investigated sample areas were ORO positive. Intracellular lipid droplets were mostly located around the ostium of an arterial branch.

Rats fed a cholesterol diet, showed a clear increase in the endothelial surface containing lipid droplets. This ORO positive area did not increase with time: $10 \%$ of the sample areas examined were ORO positive (fig.7). A similar location of these ORO positive areas, around the ostium of arterial branches, was observed; in addition, an at random distribution of the areas in the endothelial layer was seen.

CMV infection of the hypercholesterolemic rats induced an extra increase in the ORO containing endothelium; this increase was constant during the experimental time course: about $17 \%$ of the sample area examined showed lipid droplets. Further was observed that not only the area but also the number of ORO droplets/endothelial cell increased.

\subsection{DISCUSSION}

The "response to injury" hypothesis postulates that endothelial injury or dysfunction plays an essential role in the development of atherosclerotic lesions (11). A diversity of insults has been proposed, among others the well known hypercholesterolemia and recently viral infection (12).

Cytomegalovirus, which has been shown to infect endothelial cells $(17,18,19)$, is one possible candidate. To investigate if indecd CMV infection initiates carly atherosclerotic lesions, a rat-model was used. Following infection the occurrence of endothelial cell damage, leukocyte adhesion, the presence of lipophages, and the accumulation of lipids in the vessel wall were studied. For comparison, rats on an atherogenic high cholesterol diet, were used.

In hypercholesterolemic rats we found a 5-fold increase in plasma-cholesterol and a 10fold increase in plasma-LDL after 8 weeks of cholesterol diet. Further, a 21 -fold increase in number of leukocytes adhering to the aortic intima was observed. Next to adhesion, subendothelial cells were present in the aortic samples, suggesting that the adhesion of leukocytes is followed by migration into the subendothelial space in our model during hypercholesterolemia. Eventually, hypercholesterolemia in rats induced an aortic lipid accumulation: ORO, a neutral lipid stain which stains cholesterol and cholesterol esters (20) gave a positive staining of endothelial cells in cholesterol fed rats.

A similar hypercholesterolemic rat-model has been described by Joris et al. (13). The vascular lesions found in the present study are conparable to those described by these authors in the hypercholesterolemic model. Furthermore, endothelial cells loaded with lipid droplets and focal adherence of red blood cells were also observed. (13).

The adherence of leukocytes to the aortic endothelium is a sign of endothelial injury, which can be induced by hypercholesterolemia $(13,14)$, and is considered as one of the initial events in the development of an atherosclerotic lesion (21-23). Inspired by this 
information and intrigued by the described association between CMV and atherosclerosis, we investigated if CMV infection also induces leukocyte adhesion.

A significant increase in leukocyte adhesion to the endothelium was observed in CMV infected normocholesterolemic rats at 1 week p.i. This increase persisted for the entire period of observation (16 weeks p.i.). CMV infection of hypercholesterolemic rats, however, did not result in an additional increase of adhesion. It even seemed that the adhesion is reduced. A possible explanation for this lack of increase can be found in the observation that next to adhesion of leukocytes, migrated cells were present in the subendothelial space. As described, this phenomenon was more obvious in virus infected hypercholesterolemic rats than in virus infected normocholesterolemic rats, which is apparently due to the fact that hypercholesterolemia and virus infection aggravated each others effects. Further, the silver impregnated aortas derived from CMV infected normocholesterolemic and hypercholesterolemic rats, show endothelial cells with intensive silver surface staining. A similar observation was made by others in their en face preparations (24). It was presumed that those endothelial cells were damaged or dead (24). In addition, CMV infection of normocholesterolemic rats induced lipid deposition in the aortic samples. ORO gave a positive staining of endothelial cells and of some adherent leukocytes i.e. lipophages (25) in normocholesterolemic rats infected with CMV. In hypercholesterolemic rats a slight increase in lipid containing endothelial cells is observed after CMV infection, however this increase was not significant. This can be explained by the fact that the thyroid suppressive diet with high levels of cholesterol caused already such an effect on the lipid metabolism, that the more subtle effect of CMV is not visible anymore. The effect of virus infection should be seen as complementary to cholesterol induction and not as an alternative.

It is apparent from the results obtained in the present study, that the vascular lesions occurring after CMV-infection, closely resemble the atherosclerotic lesions of the hypercholesterolemic rats.

The above described observations do not answer the question what the mechanisms are by which CMV leads to atherosclerosis: i.e. how does CMV induce an increased leukocyte adhesion to the endothelial monolayer and how does it cause lipid accumulation in the vessel wall. With regard to the first question, previous in vitro studies have shown that herpesvirus infection induces interaction between endothelial cells and polymorphonuclear leukocytes or monocytes $(17,26-29)$ through induced $\mathrm{Fc}$ and $\mathrm{C} 3 \mathrm{~b}$ receptors $(30,31)$, which are involved in adhesion $(27,30)$. Next to endothelial surface changes also soluble products secreted by the infected endothelial monolayer, such as interleukins (32), prostacyclin and thrombin (33) are involved. In our laboratory we found that the CMV induced adhesion is regulated by autocrine interleukin-1 (Il-1) production through endothelial cells and by the appearance of adhesion molecules such as ELAM-1 (32) and ICAM-1 (data not published). In addition, it is possible that young, regenerating endothelial cells are somehow more sticky for leukocytes (34). In our in vivo experiment, adhesion occurred selectively in periostial areas (fig.4c), which are well known to have a high cell turnover (35).

With regard to the second question, Hajjar et ai.(4) showed that the lipids deposited in the aorta of MDV infected normocholesterolemic chickens were caused by an increase in cholesterol, cholesterol esters, triacylglycerol, and phospholipids. Similar alterations have been reproduced in vitro by infecting cultured chicken smooth muscle cells with MDV (36). Further, it is reported that HSV-1 and HSV-2 $(37,38)$ alter the metabolism of 
phospholipids, glycolipids, sphingolipids, and cholesterol in various cells. All these studies indicate that virus infection could induce perturbation of lipid metabolism in cells. A similar alteration of the cellular lipid metabolism of endothelial cells can explain the increase in cholesterol and cholesteryl esters amount observed in CMV-infected normocholesterolemic and hypercholesterolemic rats.

In conclusion, the present results indicate that the described CMV-rat model is a relevant in vivo model that may provide a tool to study these and other questions concerning the mechanisms of the atherogenic potential of CMV-infection, including virusinduced smooth muscle cell proliferation and accumulation.

Secondly, the results from the in vivo experiment support the hypothesis that viruses may play a role in formation of an atherosclerotic plaque (1-4,39), and these experimental data further substantiate the findings in humans of a possible involvement of CMVinfection in the pathogenesis of atherosclerosis.

Based on these results we propose that reactivation of a latent CMV to a local lytic infection of the vessel wall may result in an inflammatory reaction and/or in an altered endothelial or smooth muscle cell lipid metabolism and/or altered proliferative response that may lead to atheroma formation.

\subsection{ACKNOWLEDGEMENTS}

This work was supported in part by grant no. 88-235 of the Dutch Heart Foundation. The author wishes to thank W. Mullers and M. Stuart for their excellent assistance, and the department of Pathology for their cooperation during the course of the investigations.

\subsection{REFERENCES}

1. Fabricant, CG, Fabricant, J, Minick, CR, Litrenta, MM: Herpesvirus-induced atherosclerosis, Viruses in Naturally occurring Cancers. Cold Spring Harbor Conference on Cell Proliferation 1980, 7: 1251-1258.

2. Fabricant, CG, Fabricant, J, Minick, CR, Litrenta, MM: Herpesvirus induced atherosclerosis in chickens. Fed. Proc. 1983, 42: 2476-2479.

3. Minick, CR, Fabricant, CG, Fabricant, J, Litrenta, MM: Atheroarteriosclerosis induced by infection with herpes virus. Am. J. Pathol. 1979, 96: 673-706.

4. Hajjar, DP, Fabricant, CG, Minick, CR, Fabricant, J: Virus induced atherosclerosis, Herpesvirus infection alters aortic cholesterol metabolism and accumulation. Am. J. Pathol. 1986, 122: 62-70.

5. Melnick, JL, Petrie, BL, Dreesman, GR, Burek, J, McCollum, CM, Debakey, ME: Cytomegalovirus antigen within human arterial smooth muscle cells. Lancet 1983, 2: 644-647.

6. Gyorkey, F, Melnick, JL, Guinn, GA, Gyorkey, P, Debakey, ME: Herpesviridae in the endothelial and smooth muscle cells of the proximal aorta in arteriosclerotic patients. Exp. Mol. Pathol. 1984, 40: 329339.

7. Adam, E, Probtsfield, JL, Burek, J, McCollum, CH, Melnick, JL, Petrie, BL, Dailey, KR, Debakey, ME: High levels of cytomegalovirus antibody in patient requiring vascular surgery for atherosclerosis. Lancet 1987, 8: 291-293.

8. Hendrix, MGR, Dormans, PHJ, Kitslaar, P, Bosman, F, Bruggeman, CA: The presence of cytomegalovirus nucleic acids in arterial walls of atherosclerotic and nonatherosclerotic patients. Am. J. Pathol. 1989, 134: 1151-1157. 
9. Hendrix, MGR, Salimans, MMM, van Boven, CPA, Bruggeman, CA: High prevalence of latently present cytomegalovirus in arterial walls of patients suffering from grade III atherosclerosis. Am. J. Pathol. 1990, 136: 23-28.

10. Ross, R, and Glomset, JA: The pathogenesis of atherosclerosis. N. Engl. J. Med. 1976, 295: 369 (Part I) and 420 (Part II)

11. Ross, R: The pathogenesis of atherosclerosis-an update. N. Engl. J. Med. 1986, 314: 488-500.

12. Mozar, HN, Dileep, GB, Farag, SA: The natural history of atherosclerosis: an ecologic perspective. Atherosclerosis, 1990, 82: 157-164.

13. Joris, I, Zand, T, Nunnari, JJ, Krolikowshi, FJ, Majno, G: Studies on the pathogenesis of atherosclerosis. I. Adhesion and emigration of mononuclear cells in the aorta of hypercholesterolemic rats. An. J. Pathol. 1983, 113: 341-358.

14. Gabaldon, M, Capotevila, C: Adhesion of leukocytes to the aortic endothelium of conventional specific pathogen free (SPF) and hypercholesterolemic SPF rats. Atherosclerosis 1989, 75: 83-92.

15. Bruggeman, CA, Meijer, H, Dormans, PHJ, Debie, WHM, Grauls, GELM, van Boven, CPA: Isolation of a cytomegalovirus-like agent from wild rats. Arch. Virol. 1982, 73: 231-241.

16. Bruggeman, CA, Debie, WHM, Grauls, G, Majoor, G, van Boven, CPA. Infection of laboratory rats with a new cytomegalo-like virus. Arch. Virol. 1983, 189-199.

17. Span, AHM, van Boven, CPA, Bruggeman, CA: The effect of cytomegalovirus infection on the adherence of polymorphonuclear leucocytes to endothelial cells. Eur. J. Clin. Invest. 1989, 19: 542-548.

18. Sniley, ML, Mar, E, Huang, A: Cytomegalovirus infection and viral induced transformation of human endothelial cells. J. Med. Virol. 1988, 25: 213-226.

19. Span AHM, van Dam-Mieras MCE, Mullers W, Endert J, Muller AD, Bruggeman CA: The effect of virus infection on the adherence of leukocytes or platelets to endothelial cells. Eur J Clin Invest 1991, 21: $721-731$.

20. Schjeide, OA, Rivin, AU, Yoshino, J: Uptake of lipid stains by lipids and serum lipoproteins. Amer. J. Clin. Path. 1963, 39: 329-341.

21. Jerome, WG, Lewis, JC: Early atherogenesis in white carneau pigeons. I. Leukocyte margination and endothelial alterations at the celiac bifurcation. Am. J. Pathol. 1979, 116:56

22. Gerrity, RG, Naito, HK, Richardson, M, Schwartz, CJ: Dietary induced atherogenesis in swine. Morphology of the intima of prelesion stages. Am. J. Pathol. 1979, 95: 775

23. Faggiotto, A, Ross, R, Harker, L: Studies of hypercholesterolemia in the nonhuman primate. I. Changes that lead to fatty streak formation. Arteriosclerosis. 1984, 4: 323

24. Chuang, P-T, Cheng, H-J, Lin, S-J, Jan, K-M, Lee, MML, Chien, S. Macromolecular transport across arterial and venous endothelium in rats. Studies with evans blue-albumin and horseradish peroxidase. Arteriosclerosis 1990, 10: 188-197.

25. Suzuki, M, O'Neal, RM: Circulating lipophages, serum lipids, and atherosclerosis in rats. Archiv. Pathol. 1967, 83: 169-174.

26. Visser, MR, Jacob, HS, Goodman, JL, McCarthy, JB, Furcht, LT, Vercellotti GM: Granulocytemediated injury to herpes simplex virus-infected human endothelium. Lab. Invest. 1989, 60: 296-303.

27. Zajac BA, O'Neill K, Friedman HM, MacGregor RR: Increased adherence of human granulocytes to herpes simplex virus type 1 infected endothelial cells. In vitro Cell. development. biol. 1988, 24: 321325.

28. MacGregor, RR, Friedman, HM, Macarak, EJ, Kefalides, NA: Virus infection of endothelial cells increases granulocyte adherence. J. Clin. Invest. 1980, 65: 1469-1477.

29. Span AHM, Endert J, Boven CPA van, Bruggeman CA: Virus induced adherence of monocytes to endothelial cells. FEMS Microbiology Immunology 1989, 47: 237-244.

30. Friedman, HM: Viral infection of endothelium and the induction of $\mathrm{Fc}$ and $\mathrm{C}_{3}$ receptors. In: Jaffe, EA (ed.), Biology of endothelial cells. Boston: Martinus Nijhoff 1984: 268-276.

31. Kubota, Y, Gaither, TA, Cason, J, O'Shea, JJ, Lawley, TJ: Characterization of the $\mathrm{C}_{3}$ receptor induced by Herpes simplex virus type 1 infection of human epidermal, endothelial and A431 cells. J. Immunol. 1987, 138: 1137-1142. 
32. Span AHM, Mullers W, Miltenburg AMM, Bruggeman CA: Cytomegalovirus induced PMN adherence in relation to an ELAM-1 antigen present on infected endothelial cell monolayers. Inmunol. 1991, 72: 355-360.

33. Visser MR, Tracy PB, Vercellotti GM, Goodman JL, White JG, Jacob HS: Enhanced thrombin generation and platelet binding on herpes simplex virus-infected endothelium. Proc Natl Acad Sci USA 1988, 85: 8227-8230.

34. Schaper, J, König, R, Franz, D, Schaper, W: The endothelial surface of growing coronary collateral arteries: Intimal margination and diapedesis of monocytes: A combined SEM and TEM study. Virchows Arch [Pathol Anat] 1976, 370: 193-205.

35. Payling-Wright, H: Endothelial mitosis around aortic branches in normal guinea pigs. Nature 1968, 200 : 78-79.

36. Fabricant, CG, Hajiar, DP, Minick, CR, Fabricant, J: Herpesvirus infection enhances cholesterol and cholesteryl ester accumulation in cultured arterial smooth muscle cells. Am. J. Pathol. 1981, $105: 176$ 184.

37. Schroeder, CW, Merrick, JM: Alterations in glycosphingolipid patterns in a line of african green monkey kidney cells infected with herpes virus, J.Virol. 1979, 32: 734-740.

38. Visser, MR, Vercellotti, GM, Goodman, JL, McCarthy, JB, Furcht, LT, Jacob, HS: Herpes Simplex virus infection promotes granulocyte-mediated endothelial detachment by altering extracellular matrix proteins, cytoskeleton and membrane phospholipids. Clin. Res. 1987, 35: 434a.

39. Minick CR, Fabricant CG, Fabricant J, Litrenta MM: Atheroarteriosclerosis induced by infection with a herpesvirus. Am J Pathol 96: 673, 1979. 


\section{CHAPTER IV}

CMV INDUCED VASCULAR INJURY: AN ELECTRON-MICROSCOPIC STUDY IN THE RAT

*Span AHM, Frederik PM, Grauls G, van Boven CPA, Bruggeman CA.

Submitted for publication. 


\begin{abstract}
The Marek's disease virus infection experiments performed by Fabricant et al. provided strong evidence in support of a viral etiology for atherosclerosis. In this study, we denonstrate that another herpesvirus, namely rat-CMV caused in rats fed with a low-cholesterol diet alterations of the endothelium and subendothelial space, similar to the alterations induced by hypercholesterolemia. Rats infected with CMV showed a minimal damage of the endothelium. In addition, lipid accumulation occurred in the endothelium and in the subendothelial space. The lipid accumulation in the subendothelial space consisted of extracellular lipid deposition and of intercellular as subendothelial located "foamcells". Also lymphocytes accumulated in the subendothelium. A characteristic phenomenon of the effect of CMV infection of rats was a loosening of the endothelial cells from the basement membrane. The space between the basement membrane and endothelium was expanded and it was filled with an increased amount of reticular basal lamina-like material. These observations further support the proposed etiologic role of herpesviruses in atherosclerosis.
\end{abstract}




\subsection{INTRODUCTION}

The disturbance of the integrity of vascular endothelial cell layer is generally considered as one of the first steps in the development of atherosclerosis. It has been suggested that this development is initiated by several risk factors (1). Of these risk factors hypercholesterolemia has received most attention (2-4). Recently, Ross (5) postulated two pathogenic pathways that lead to atherogenesis. The first pathway involves hypercholesterolemia and is associated with increased monocyte adherence, smooth muscle cell (SMC) migration and proliferation, lipid accumulation, foam cell formation, and the formation of fatty streaks. The second pathway involves direct stimulation of endothelium and the release of growth factor that induce proliferation and migration of SMC. The role of herpesviruses, as possible initiators of atherogenesis, is suggested for the latter pathway (6).

Supporting evidence on the role of virus in the pathogenesis of atherosclerosis was found in in vivo studies where normocholesterolemic chickens infected with Marek disease virus, a herpesvirus, developed atherosclerotic lesions (7-11). An additional support was found in a recent in vivo study which describes the presence of early vascular lesions in normocholesterolemic rats after CMV infection (12). As observed by light microscopy those lesions were characterized by increased adherence of leukocytes to the aortic intima, presence of lipophages, accumulation of lipid in the endothelium, and minimal endothelial damage (12).

Consistent with these in vivo observations, we and others have shown that granulocytes and monocytes are attracted to (13-17), and damage (17), virus infected endothelium in vitro. In addition, it was reported that HSV infection of human endothelial cells in vitro inhibits the interaction of endothelial cells with purified basement membrane proteins, which results in weakened tethering to the substratum. It was suggested that this tethering is inadequate for proper endothelial cell spreading or movement to occur and may result in both endothelial lift-off and impaired vascular repair (18). Taken together, above described observations suggest that virus could be an important contributing factor in vascular damage.

In this study we employed scanning (SEM) and transmission electron (TEM) microscopy to investigate the virus induced vascular changes on cellular and subcellular level with special attention to the question whether virus infection in vivo might diminish the interaction between endothelial cells and basement membrane or extracellular matrix proteins, as reported in in vitro studies $(18,19)$. In addition, we compared the lesions induced by CMV with those induced by hypercholesterolemia. As controls served, a group of rats fed a high-cholesterol diet and a group of noninfected rats fed a low-cholesterol diet. 


\subsection{MATERIALS AND METHODS}

\subsubsection{Virus stock}

In this study a rat cytomegalovirus (CMV) was used. The CMV stock was isolated in our laboratory (20) and was maintained by passaging the salivary gland suspensions intraperitoneally in three to four weeks old Brown Norway rats as described previously (21). Briefly, after 3 weeks virus was harvested from the salivary glands by homogenizing these organs in a tissue grinder. The resulting homogenates were diluted to 10 percent $(w / v)$ in Eagles Minimal Essential Medium and stored at $-80^{\circ} \mathrm{C}$ until use. The virus stock used in this study had a strength of $10^{6}$ plaque forming units (PFU) $/ \mathrm{ml}$.

\subsubsection{Rats}

A group of specific pathogen free (SPF) Wistar rats were used in this study. They were bred at the department of experimental Ainimal Services, University of Limburg Biomedical Center, Maastricht, The Netherlands. The rats were free of all known viral and microbial pathogens, which can cause spontaneous pathology in rats (3) (SPF-stock).

\subsubsection{Design of the experiment}

SPF-rats, weighing 200-225 gram were at random selected from the stock. These rats were initially fed a commercial diet (Hopefarms, Woerden, The Netherlands) relatively low in cholesterol (less than $0.02 \%$ cholesterol by weight: "low-cholesterol" diet). After 3 weeks of low-cholesterol diet, half of the rats changed to a diet supplemented with $4 \%$ cholesterol (w/v), $1 \%$ cholic acid and $0.5 \%$ 2-thiouracil ("high-cholesterol" diet) as described (2). After 7 weeks on a high-cholesterol diet half of these rats, were inoculated intraveneously (i.v.) with $4 \times 10^{5} \mathrm{PFU} / \mathrm{ml} \mathrm{CMV}$. At the same time half of the rats fed with the low-cholesterol diet were infected. These infected rats were housed, strictly separated from the remaining noninfected rats during the entire experiment. The infected rats were sampled at similar time intervals as used in our previous study (12): after 1, 4, 8 and 16 weeks of infection rats were randomly selected from the infected groups and necropsied. The infected or noninfected rats fed a high-cholesterol diet were necropsied at the same times, and thus were fed for $8,11,15$, and 23 weeks on a atherogenic diet.

\subsubsection{Electron microscopy}

To minimize tissue alterations prior to chemical fixation, aortas were fixed by perfusion in situ in anesthetized animals. Perfusion was carried out under controlled pressure (110 $\mathrm{mmHg}$ ) as described previously (12). To visualize the endothelial cell boundaries some of the samples were perfused, with $0.05 \%$ silver solution for $1 \mathrm{~min}$. and bromides (3\% $\mathrm{CoBr}, 1 \% \mathrm{NH}_{4} \mathrm{Br}$ ) for $1 \mathrm{~min}$. respectively, directly after the initial perfusion with glutaraldehyde $(2.5 \%$ in phosphate buffer, $7 \mathrm{~min}$.). After perfusion fixation (and silver 
staining) a $20 \mathrm{~mm}$ segment of the abdominal aorta was excised, left in $2.5 \%$ glutaraldehyde for a total fixation time of 24 hours and immersed in cacodylate buffer overnight.

A $10 \mathrm{~mm}$ long segment was postfixed in $1 \%$ osmium tetroxide (OsO4), dehydrated in graded alcohols, cut into transversely rings and embedded in Epon 812, respectively. One micron sections were stained with toluidine blue for light-microscopic examination. Ultrathin sections were cut on a diamond knife using a Reichert OmU3 or Reichert Ultracut, mounted on copper grids, stained with uranyl acetate and lead citrate, and studied with a Philips CM12 or an EM 400 electron microscope.

The $10 \mathrm{~mm}$ samples for the SEM were dehydrated in graded alcohol, immersed in $100 \%$ ethanol and dried by the critical-point method. The samples were sputtercoated with gold, and micrographs were taken with a Philips CM12 or Cambridge SV 180 scanning microscope using the secondary electrons.

\subsection{RESUL'TS}

\subsubsection{SEM}

To investigate whether a high-cholesterol diet and/or CMV have an effect on the morphology of the endothelium or on the interaction between the endothelium and circulating blood cells SEM preparations were observed.

The luminal surfaces of the abdominal aortas derived from noninfected rats fed a lowcholesterol diet were lined by a continuous sheet of endothelial cells with clearly delineated cell boundaries. These endothelial cells were mainly rhomboidal in outline and oriented with their long axis in the direction of the blood flow. The area of the endothelial cells containing the nucleus projected slightly into the lumen of the vessel (fig.1a). Hardly any white blood cells were found adhering to the endothelial cell surfaces.

In infected rats fed a low-cholesterol diet the luminal surface of the aorta was similar to that observed in noninfected rats at week 4 p.i., but at 8 weeks p.i. some morphological changes could be detected in the endothelial cells. Cell margins started to lift up to become partially detached (fig. lb) from the underlying tissue, however without signs of denudation of the endothelial cell layer. The cell boundaries in these affected areas were faint and sometimes invisible. Platelets were found adhering to these areas. They were attached to the endothelial surface as well as to adherent mononuclear cells. In some samples, lipophages (i.e. cells filled with fat) attached to the endothelium were visible (fig.lc). Between areas of these altered cells, normal endothelium was found, structurally similar to the endothelium of noninfected rats fed a low-cholesterol dict. At week 16 p.i., structural changes were more prominent than at week 8 p.i. (data not shown).

In noninfected rats fed a high-cholesterol diet similar structural changes in endothelial surface were observed as found in CMV-infected rats fed a low-cholesterol diet. The preparations showed curled up endothelial cells and partially detached endothelial cells from the underlying tissue (fig.1d). Cell boundaries were hardly visible. These signs of damage were more frequently observed in these rats than in infected rats fed a lowcholesterol diet.

SEM preparations obtained from CMV-infected fat-fed rats were not different from noninfected fat-fed rats. Curled up endothelial cells and partially detached endothelial cells 
were observed with a comparable frequency. In addition cell boundaries were faint or not detected by silver staining (data not shown).
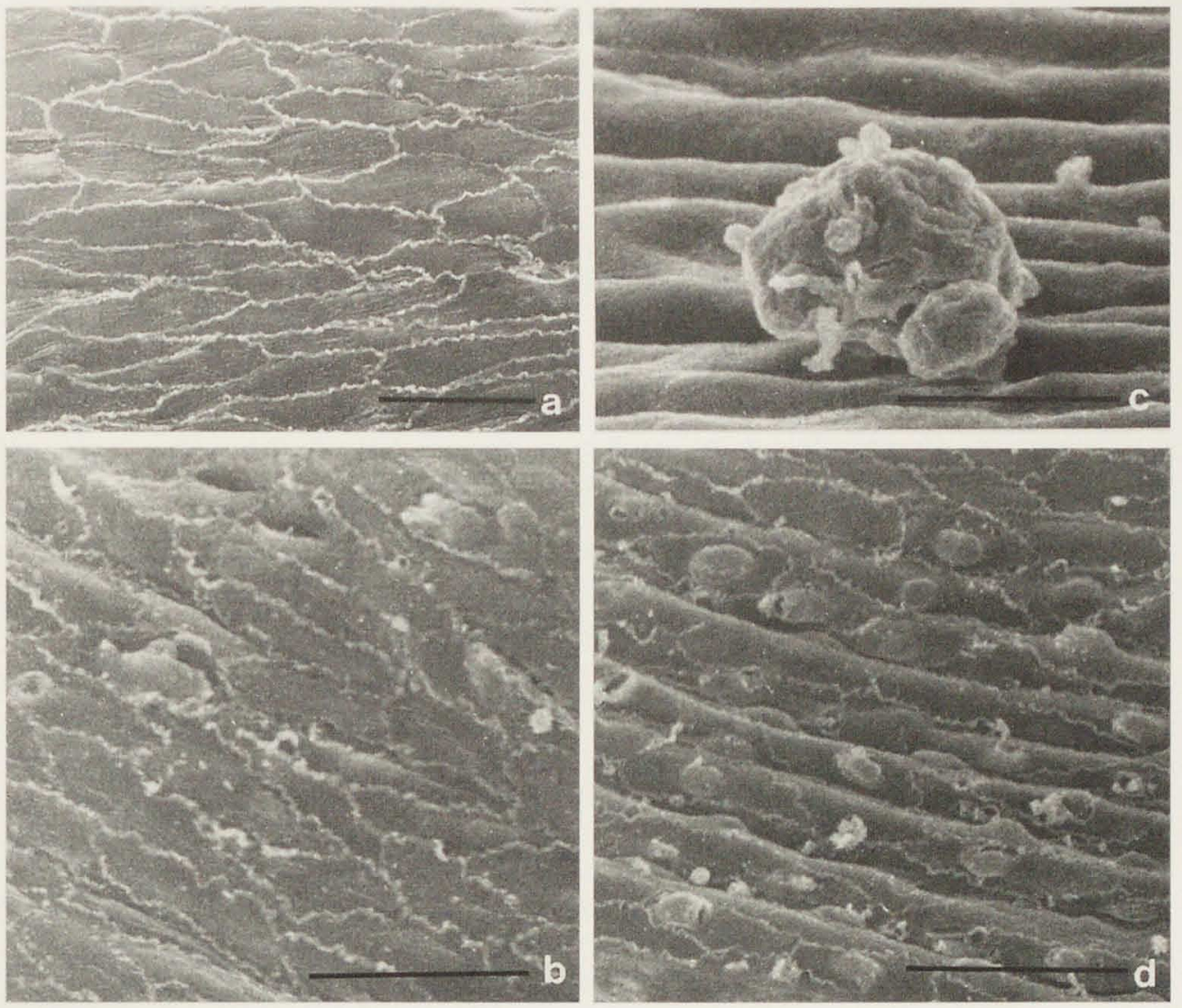

fig.1: SEM preparation of a silver impregnated aorta derived from a noninfected rat fed a low-cholesterol diet. Intact endothelium was observed (a). Endothelium derived from an infected rat fed a low-cholesterol diet showed after silver impregnation, at 8 weeks p.i., cell margins which became partially detached (b) from the underlying tissue. Lipophages were attached to the endothelium (c). The preparation of a silver impregnated aorta of a noninfected rat fed a high-cholesterol diet showed curled up endothelial cells and partially detached endothelial cells from the underlying tissue (d). Bar represents $30 \mu \mathrm{m}$ for a,b,d. Bar represents $10 \mu \mathrm{m}$ for $\mathrm{c}$. 


\subsubsection{TEM}

The areas with surface changes as observed in SEM were investigated by TEM to resolve the involvement of deeper laying structures in the lesions induced by CMV infection and by high-cholesterol diet.

The TEM examination of the abdominal aorta of rats fed a low-cholesterol diet showed endothelium lined by a basement membrane. This membrane was resting directly on the internal elastic lamina. Between the elastic lamina and the basement membrane a thin "reticular" layer was visible, consisting of basement membrane like material mixed with collagen fibrils (fig.2a). White blood cells, adhering to the endothelium, were only seldomly observed. The vascular ultrastructure stayed similar over the experimental period.

In the aortas of infected rats fed a low-cholesterol diet, endothelial cells were found to be released from their basement membrane. Such observations were already made at one week post infection. Other endothelial cells were swollen and contained several lipid droplets (fig.2b). These droplets were round or oval, with their long axis perpendicular to the luminal surface and sometimes protruding above it. Some of these lipid droplets were not bound by a visible limiting membrane, while most of them were. Relatively small numbers of lipid free mononuclear cells were present under the endothelial surface after 1 week of infection (fig.2c). The morphology of most of these cells was consistent with that of lymphocytes (dense aggregated nuclear chromatin, a large nuclear/cytoplasmic ratio, and a few poorly developed intracytoplasmic organelles). Occasionally a myelin figure was found, which was complex and electron dense, and localized under the endothelial cells (fig.2d). After CMV infection the space between the endothelial cells and the basement membrane tended to expand and basal lamina-like material was present. Collagen fibrils and elastic fibers were increased in the subendothelium of these rats in comparison with the noninfected rats (fig.2e). After 4, 8, and 16 weeks of infection similar ultrastructural changes were observed.

The endothelial cells observed in the aortic samples derived from rats fed a highcholesterol diet were occasionally swollen, and contained frequently lipid droplets. Also membranous globules and deposits within the cytoplasm were frequently visible, suggesting breakdown of the amorphous lipid droplets (fig.3a). In addition, cells filled with lipid droplets were observed under the endothelium: in the subendothelial space (fig.3b). A coarse reticulum probably basal lamina-like material filled the subendothelium in these rats. The subendothelium, did not contain more collagen fibrils or elastic fibers.

The vessel wall of CMV-infected rats fed a high-cholesterol diet showed similar characteristics as noninfected fat-fed rats, but in an advanced state at $1,4,8$, and 16 weeks p.i.: subendothelial cells were present more frequently and contained a higher amount of lipid droplets, which gave them the characteristics of foam cells (fig. 3c). Most of these areas with foam cells were covered by endothelium: no foci of denuded endothelial cells were observed. The space between the endothelial cells and the basement membrane was expanded and it was filled with a large amount of basal lamina-like material (fig.3d). In addition, the aortic samples of the fat-fed rats taken 8 weeks after CMV infection revealed endothelial cells in which the nucleus was deformed (fig.3e). In the cytoplasm of these cells cytomegalo-dense bodies were observed. These dense bodies had homogenous, fine granular appearances and diameters between 200 and $500 \mathrm{~nm}$. They 

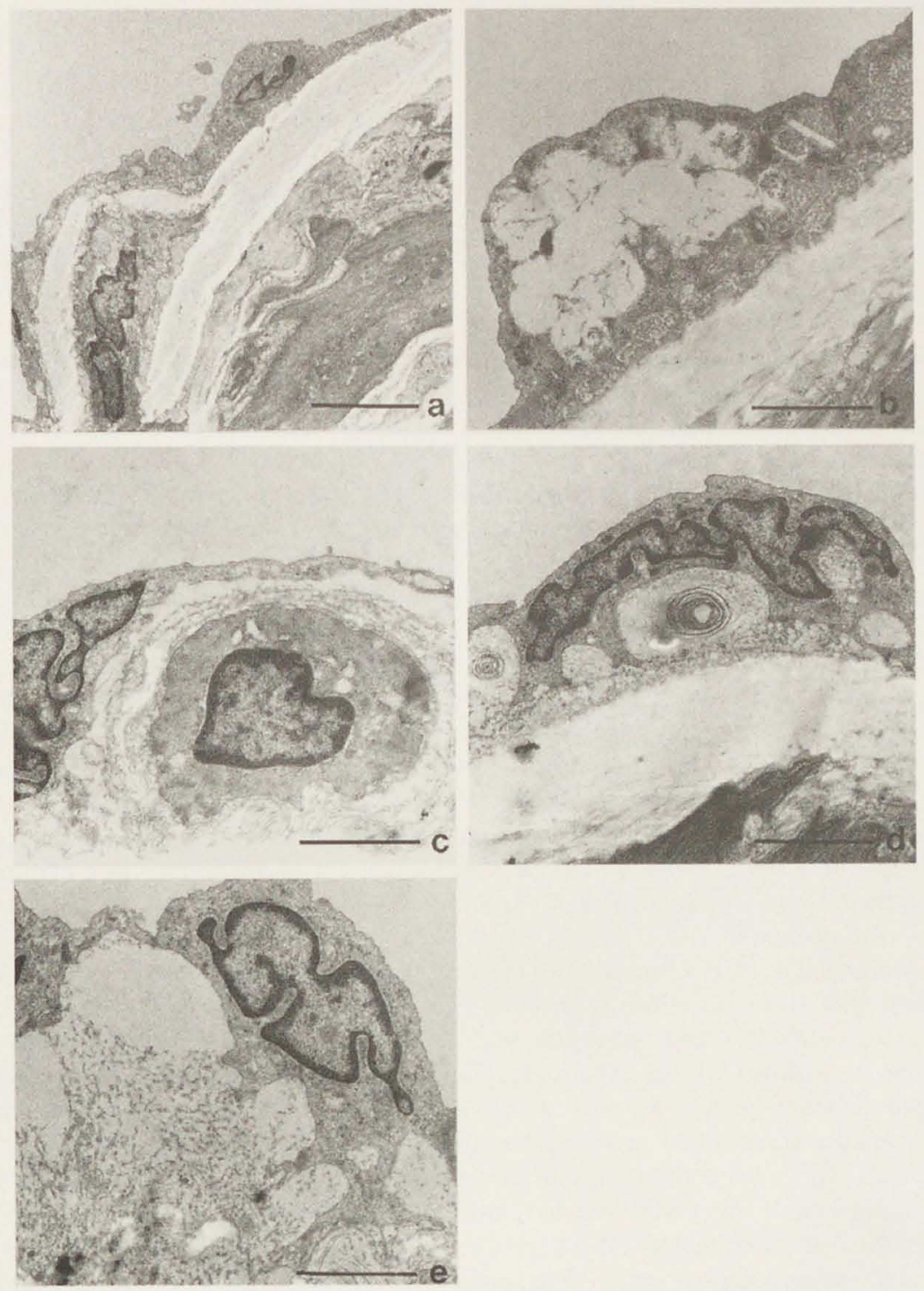

fig. 2: TEM preparation of the abdominal aorta of a rat fed a low-cholesterol diet. Endothelium is lined by a basement membrane resting directly on the internal elastic lamina. Bar represents $5 \mu \mathrm{m}$ (a). Endothelium of a CMV-infected rat contained lipid droplets already at 1 week p.i. (b); Nonlipid filled lymphocytes (c) and electron-dense myelin figures (d) were sometimes present in the subendothelial space; after CMV infection the subendothelial space was expanded (e). Bar represents $2.5 \mu \mathrm{m}$ for b-e. 

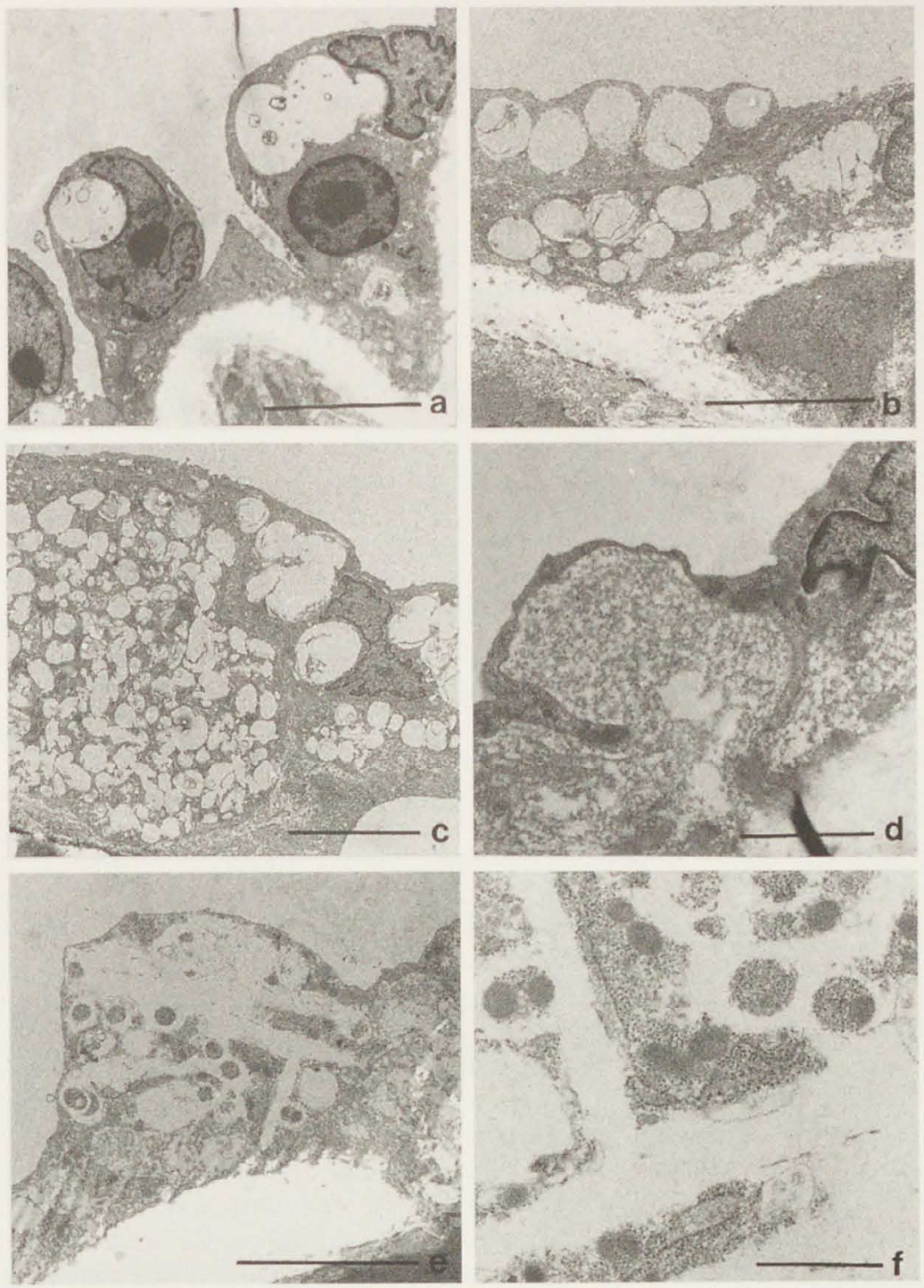

fig.3: Aortic endothelium of a rat after 8 weeks on a high-cholesterol diet. Lipid droplets and membranous globules and deposits were frequently present in the endothelial cells (a) and in cells located in the subendothelial space (b). The aortic intima of CMV-infected rats fed a high-cholesterol diet showed at 1 week p.i. subendothelial cells with a higher amount of lipid droplets, which gave them the characteristics of foam cells (c). The space between the endothelium and basement membrane was extensively expanded and filled with an increased amount of basal lamina-like material (d). The aortic samples of fat-fed rats revealed at 8 weeks p.i. endothelial cells in which the nucleus was deformed (e). In the cytoplasm cytomegalo-dense bodies were observed (f) with diameters between 200 and $500 \mathrm{~nm}$. Bar represents $5.0 \mu \mathrm{m}$ for a-e, or $1 \mu \mathrm{m}$ for $f$. 
were bounded by an envelope structure, that was estimated to be $10 \mathrm{~nm}$ in thickness (fig.3f). Some of these dense bodies were surrounded by electron dense matrix material (fig.3f).

\subsection{DISCUSSION}

Recently, we described in an in vivo study performed in rats that early atherogenic events are induced by CMV infection and by a high-cholesterol diet (12). By light microscopy the following alterations were observed (12): a minimal endothelial cell damage, the presence of lipophages, increased adherence of leukocytes to the aortic intima followed by migration to the subendothelium, and lipid accumulation in the endothelium. To further investigate these events we started an electron microscopic study.

In this ultrastructural study, using TEM and SEM, we investigated, whether the cellularand sub-cellular changes that occur in our rat-model after CMV infection are similar to, or different from, those that occur during hypercholesterolemia.

A comparison, made between CMV-infected rats fed a low-cholesterol diet and noninfected rats fed a high-cholesterol diet, shows that similar vascular alterations occurred in the fat-fed rats when viewed with SEM. In both groups we observed adhesion of platelets and of a few leukocytes, and no adherence of microthrombi. Furthermore, the basement membrane was not denuded of endothelial cells cells. However, these structural changes are more pronounced in the noninfected fat-fed rats than in CMV-infected rats.

In the atherosclerotic model used by Joris et al. (2) comparable vascular lesions are described. Based on these observations some degree of platelet adhesion should be expected; a quantitive study of platelet adhesion in hypercholesterolemic monkeys has shown a rise in adherence as early as 10 days (22). The lack of denudation can be reconciled with the studies of Schwartz, and Reidy \& Schwartz, who showed that dying, single endothelial cells are "undermined" by their neighbors before they slough off to ensure that the subendothelium is not directly exposed to blood $(23,24)$.

The thin sections examined by TEM also displayed alterations in noninfected fat-fed rats resembling those seen in CMV-infected rats fed a low-cholesterol diet: endothelial cells filled with lipid droplets, extracellular lipid deposition in the subendothelial space, and non-lipid filled lymphocytes under the endothelium were present in the aortic samples. The presence of fat in the vessel wall suggests that virus infection in vivo may induce a "fatty streak" when normal -low cholesterol- feeding conditions are used. The presence of lymphocytes in the subendothelium has also been described in other hypercholesterolemia studies (25-27). Masuda and Ross (27) recently described that the subendothelial lymphocytes were largely CD8-positive being intermixed with relative small numbers of CD4-positive cells. But, also atherosclerotic lesions found in man revealed the involvement of the immune system (28).

Although most types of lesions of noninfected fat-fed rats and CMV infected rats are comparable, still some structural changes seem to be peculiar to CMV-infected rats.

A loosening of the endothelial cells from the basement membrane was usually observed in these rats: the space between the endothelial cells and the basement membrane was expanded, it was filled with an increased amount of reticular lamina-like material. Furthermore, the subendothelial space was increased more collagen fibrils and elastic 
fibers were present. This loosening of endothelial cells observed during CMV infection is in accordance with the observation made in an in vitro study described by Visser et al. (18). He reported that adhesion, spreading, and migration of HSV infected endothelial cells to basement membrane proteins is greatly reduced, or entirely eliminated (18). In noninfected fat-fed rats this amount was not increased, neither were the collagen fibrils nor the elastic fibers. This latter observation is in accordance with the observations described by Nakamura et al. (25) during hypercholesterolemia.

Thus, it seems that the noninfected fat-fed rats in our study show similar cellular and subcellular changes in the aortic intima as those induced by hypercholesterolemia seen in other reports. CMV, however, induces in addition to the above described alterations other ultrastructural changes which are revealed by TEM.

An additional effect of CMV infection in fat-fed rats could not be demonstrated using SEM. Probably, the cholesterol diet causes already such an effect that the subtle CMV changes are not perceptible by SEM anymore. Nevertheless, the TEM observations show that CMV infection can induce different ultrastructural changes: again a loosening of the endothelial cells from the basement membrane is observed in these rats: caused by an increased amount of reticular basal lamina-like material. An other interesting observation is the presence of "Cytomegalo-dense bodies" in the infected fat-fed rats. This suggests that a number of endothelial cells became infected, probably in a abortive way. The presence of the dense bodies in CMV infected cells is also described in vitro (29-31). 90\% of its protein is matrix protein of $\mathrm{Mr} 69000$ together with envelope glycoproteins $(30,32)$.

In conclusion, it seems that CMV infection of the arterial wall induces in rats highly comparable early cellular events and interactions as those described during hypercholesterolemia. The cellular events induced by CMV seem to represent a type of inflammatory response. It includes leukocyte adherence to endothelium and subendothelial penetration and migration of these leukocytes (12). Furthermore, minimal endothelial cell damage, an increase in the amount of subendothelial material, and an increase in intracellular lipid deposition is induced. These early observed events do support a viral etiology in atherosclerosis, and the following pathway is suggested: virus infection of the endothelial cells causes a loose attachment of these cells to the basement membrane by which these cells become more vulnerable to detachment mediated by granulocytes, that eventually may result in vascular wall damage. To substantiate this possible pathway and others, including periodic reactivation of a latent infection that can lead to chronic immune injury $(33,34)$; virus infection may alter lipid metabolism that may lead to the accumulation of cholesterol (35); and/or herpes viruses have transforming genes $(36,37)$ that could potentiate the abnormal proliferation of SMC which is believed to be the key event in the atherosclerotic plaque formation $(5,38)$, need further study and availability of additional markers is required. An immunocytochemical investigation with markers for virus products, cell adhesion molecules, interleukins, and basement membrane components may provide more insight in the similarities and differences between CMV and diet induced lesions. Such a study may also provide more insight information of the precise cellular mechanisms involved. 


\subsection{ACKNOWLEDGEMENTS}

This work was supported in part by grant no 88-235 of the Dutch Heart Foundation. The author wishes to thank MCA Stuart and PHH Bomans for their excellent technical assistence.

\subsection{REFERENCES}

1. Virella G, Lopes-Virella MF: Infections and atherosclerosis. Transplant Proceed 19 (suppl 5): $26-35$, 1987.

2. Joris I, Zand T, Nunnari JJ, Krowlikowski FJ, Majno G: Studies on the pathogenesis of atheroselerosis. I. Adhesion and emigration of mononuclear cells in the aorta of hypercholesterolemic rats. Am J Pathol 113: $341-358,1983$.

3. Gabaldon M, Capotevila C: Adhesion of leukocytes to the aortic endothelium of conventional specific pathogen free (SPF) and hypercholesterolemic SPF rats. Atherosclerosis 75: 83-92, 1989.

4. Lupu F, Danaricu I, Simionescu N: Development of intracellular lipid deposits in lipid-laden cells of atherosclerotic lesions. A cytochemical and ultrastructural study. Atherosclerosis 67: 127-142, 1987.

5. Ross R: The pathogenesis of atherosclerosis-an update. N Engl J Med 314: 488-500, 1986.

6. Mozar HN, Bal DG, Frag SA: The natural history of atherosclerosis: an ecologic perspective: viewpoint, Atherosclerosis 82:156-164, 1990.

7. Fabricant CG, Fabricant J, Minick CR, Litrenta MM: Herpesvirus induced atherosclerosis in chickens. Fed Proc 42: 2476-2479, 1983.

8. Minick CR, Fabricant CG, Fabricant J, Litrenta MM: Atheroarteriosclerosis induced by infection with herpes virus. Am J Pathol 96: 673-706, 1979.

9. Hajjar DP, Fabricant CG, Minick CR, Fabricant J: Virus induced atherosclerosis. Herpesvirus infection alters aortic cholesterol metabolism and accumulation. Am J Pathol 122: 62-70, 1986.

10. Fabricant CG, Fabricant J, Litrenta MM, Minick CR: Virus induced atherosclerosis. J Exp Med 148: $335-340,1978$.

11. Fabricant CG, Krook L, Gillespie JH: Virus induced cholesterol crystals. Science 181: 566-567, 1973.

12. Span AHM, Grauls G, Bosman F, van Boven CPA, Bruggeman CA: CMV induces vascular injury in the rat: a model for the study of early atherosclerotic lesions. Submitted for publication.

13. Span AHM, Endert J, Boven CPA van, Bruggeman CA: Virus induced adherence of monocytes to endothelial cells. FEMS Microbiol Imnunol 47: 237-244, 1989.

14. Span AHM, van Dam-Mieras MCE, Mullers W, Endert J, Muller AD, Bruggeman CA: The effect of virus infection on the adherence of leukocyles or platelets to endothelial cells. Eur J Clin Invest 21: 721 $731,1991$.

15. Span AHM, van Boven CPA, Bruggeman CA: The effect of cytomegalovirus infection on the adherence of polymorphonuclear leucocytes to endothelial cells. Eur J Clin Invest 19: 542-548, 1989.

16. Span AHM, Mullers W, Miltenburg AMM, Bruggeman CA: Cytomegalovirus induced adherence in relation to an ELAM-1 antigen present on infected endothelial cell monolayers. Immunology 72 : 355 $360,1991$.

17. Visser MR, Vercellotti GM, Goodman JL, Jacob HS: Granulocytes injure herpes simplex virus type Iinfected endothelial cells: Implications for atherosclerosis. Clin Res 34: 959A, 1986.

18. Visser MR, Vercellotti GM, McCarthy JB, Goodman JL, Herbst TJ, Furcht LT, Jacob HS: Herpes simplex virus inhibits endothelial cell attachment and migration to extracellular matrix proteins. Am J Path 134: 223-230, 1989.

19. Visser MR, Vercellotti GM, Goodman JL, McCarthy JB, Furcht LT, Jacob HS: Herpes simplex virus infection promotes granulocyte-mediated endothelial cell detachment by altering matrix proteins, cytoskeleton and membrane phospholipids. Clin Res 35: 434A, 1987. 
20. Bruggeman CA, Meijer H, Dormans PHJ, Debie WHM, Grauls GELM, van Boven CPA: Isolation of a cytomegalovirus-like agent from wild rats. Archiv. Virol 73: 231-241, 1982.

21. Bruggeman CA, Debie WHM, Grauls G, Majoor G, van Boven CPA: Infection of laboratory rats with a new cytomegalo-like virus. Archiv. Virol: 189-199, 1983.

22. Armstrong ML, Peterson RE, Hoak JC, Megan MB, Cheng FH, Clarke WR: Arterial platelet accumulation in experimental hypercholesterolemia. Atherosclerosis 36: 89-100, 1980.

23. Schwartz SM: Role of endothelial integrity in atherosclerosis. Artery 8: 305-314, 1980.

24. Reidy MA, Schwartz SM: Endothelial injury and regeneration: IV. Endotoxin: a non-denuding injury to aortic endothelium. Lab Invest 48: 25-34, 1983.

25. Nakamura $H$, Jzumiyama $N$, Nakamura $K$, Ochtsubo K: Age-associated ultrastructural changes in the aortic intima of rats with diet-induced hypercholesterolemia. Atherosclerosis 79: 101-111, 1989.

26. Joris I, Stetz E, Majno G: Lymphocytes and monocytes in the aortic intima. An electron-microscopic study in the rat. Atherosclerosis 34: 221-231, 1979.

27. Masuda J, Ross R: Atherogenesis during low level hypercholesterolemia in the nonhuman primate. I. Fatty streak formation. Arteriosclerosis 10: 164-177, 1990.

28. Libby P, Hansson GK: Biology of disease: Involvement of the immune system in human atherosclerosis: Current knowledge and unanswered questions. Lab Invest 64: 5-15 1991.

29. Jwasaki $Y$, Furukawa $T$, Koprowski H: Ultrastructural study on the sequence of human cytomegalovirus infection in human diploid cells. Arch Ges Virusforsch 40: 311-324, 1973.

30. Irmiere A, Gibson W: Isolation and characterization of a noninfectious virion-like particle released from cells infected with human strains of cytomegalovirus. Virology 130: 118-133, 1983.

31. Griffiths PD, Grundy JE: Molecular biology and immunology of cytomegalovirus (review). Biochem J 241: 313-324, 1987

32. Sarov 1, Abady I: The morphogenesis of human cytomegalovirus; isolation and polypeptide characterization of cytomegalovirions and dense bodies. Virology 66: 464-473, 1975.

33. Snith KO, Gehle WD, Sanford BA: Evidence for chronic viral infections in human arteries. Proc Soc Exp Biol Med 147: 356-360, 1974.

34. Tumilowize JJ, Gawlik ME, Powell BB, Trentin JJ: Replication of cytomegalovirus in human arterial smooth muscle cells. J Virol 56: 839-45, 1985.

35. Fabricant CG, Haijar DP, Minick CR, Fabricant J: Herpesvirus infection enhances cholesterol and cholesterol ester accumulation in cultured arterial smooth muscle cells. Am J Pathol 105: 176-184, 1981.

36. Spector DH, Spector SA: The oncogenic potential of human cytomegalovirus. Prog Med Virol 29: 45$89,1984$.

37. Green M: Transformation and oncogenesis: DNA viruses. In: Fields B, ed. Virology. New York: Raven Press, pp 219-221, 1985.

38. Thomas WA, Kim DN: Biology of disease. Atherosclerosis as a hyperplastic and/or neoplastic process. Lab Invest 48: 245-255, 1983. 



\section{CHAPTER V}

VIRUS INDUCED MONOCYTES ADHERENCE TO ENDOTHELIAL CELLS IN CULTURE

*Span AHM, Endert J, van Boven CPA, Bruggeman CA.

FEMS Microbiology Immunology 47: 237, 1989 


\section{ABSTRACT}

In this study we have demonstrated that infection of human umbilical vein endothelial cells (HUVEC) with Herpes simplex virus type 1 (HSV-1) resulted in an increased adherence of monocyles (MC). This enhanced adherence occured at $3 \mathrm{~h}$ post infection (p.i.) when about $20 \%$ of the monolayer is infected and when there is no cytopathic effect observable in the monolayer.

The adherence of hunan MC to virus infected HUVEC monolityers proved to be effective and reproducible if a multiplicity of infection (MOI) of 10 and a ratio of number of $M C$ to number of HUVEC of 5 was used. The increased adherence was also induced by incubating non-infected HUVEC with the "supernatant medium" of the HSV-1 infected cells, showing that soluble factors induced by viral infection are responsible for the increased adherence.

The augmentation of $M C$ adherence to infected endothelium was sensitive to tunicamycin treatment, suggesting that the MC adherence is probably mediated by glycoproteins expressedon the HUVEC membranes by virus infection. 


\subsection{INTRODUCTION}

It is generally accepted that the initial event leading to the development of an atherosclerotic lesion consists of the damage of the endothelial cell layer $(1,2)$. A diversity of insults, such as mechanical (3), immunologic (4), chemical (5) or infectious processes have been proposed as causes of endothelial cell damage. The evidence supporting the involvement of virus in the pathogenesis of artherosclerosis was reported by Fabricant and colleagues $(6,7)$. They observed that Marek's disease herpesvirus (MDV) leads to occlusive atherosclerosis of the large arteries in hypercholesterolemic but also in normocholesterolemic chickens. The presence of MDV specific antigen in arterial walls of ckicken with arterial lesions suggested that MDV is directly involved in the pathogenesis of these lesions (8).

These observations stimulated interest in the investigation of a possible relationship between herpesviruses and human atherosclerosis. Gyorkey (t al. (9) described the presence of herpes virions and Melnick et al. (10) detected cytomegalovirus (CMV) antigens in smooth muscle cells (SMC) derived from the aorta of patients with atherosclerosis. In addition, Benditt et al. (11) detected herpes simplex viral genome in aortic wall-tissue specimens obtained from patients undergoing coronary artery by-pass surgery. Recently Adam et al. (12) have demonstrated high levels of CMV antibody in atherosclerotic patients.

Irrespective of the precise nature of the initial insult involved, the earliest event associated with endothelial cell (EC) damage is an enhanced interaction of EC with leukocytes and platelets (1.3). The enhanced adherence of phagocytic cells to EC can be explained by changes in the membrane composition of $\mathrm{EC}$.

EC damage or EC stimulation with interleukin-1 (IL-1) leads to increased synthesis of platelet activating factor (PAF) $(14,15)$, which mostly remains cell-associated and may mediate enhanced adherence of polymorphonuclear cells (PMN) (16). Alternatively, endotoxin (LPS), IL-1 and tumor necrosis factor (TNF) have been reported to induce the synthesis of EC membrane receptors for the GP150 (CDw 18) adhesion glycoprotein of the PMN leukocyte (17). A similar enhanced interaction between membrane structures on EC and monocytes (MC) may be responsible for the enhanced adherence seen in the early stages of atherosclerosis $(13,17)$.

The development of techniques for the culture of vascular endothelium in virro has created the opportunity to study the interaction of leukocyte suspensions and EC monolayers under controlled conditions. MacGregor a al. (18) studied the influence of virus infection of EC on the granulocyte adherence, and demonstrated that virus infection increased granulocyte adherence. Aware of their work, and as it may never be possible to determine with certainty the specific sequence of events that lead to atherosclerosis in man $(1,19)$, we examined the effect of HSV-1 infection of EC monolayers in vitro. Endothelial "injury" is postulated to produce atherosclerosis, and endothelial injury can be initiated by virus infection (20). Because the disease atherosclerosis is a chronic process, we were interested in the adherence of MC to "injured" endothelium and not in that of granulocytes, which are more active in acute processes, which is why the effect of herpesvirus infection of endothelial cell monolayers on the adherence of $\mathrm{MC}$ was investigated. Infection of endothelial cell monolayers and variability in the infection dose and in the amounts of $\mathrm{MC}$ 
are described. The results indicate that infection of endothelial cells correlates well with an enhancement in the adherence of MC.

\subsection{MATERIALS AND METHODS}

\subsubsection{Cell cultures}

Human endothelial cells (HUVEC) were obtained from umbilical cord veins by exposing the lumen of the vessel to $0.125 \%(\mathrm{v} / \mathrm{v})$ trypsin for $20 \mathrm{~min}$. The cells were cultured in plastic wells precoated with fibronectin $(0.01 \%)$ in growth medium consisting of $50 \%$ medium 199 (M 199) and 50\% RPMI 1640, supplemented with 20\% fetal calf serum (FCS), heparin $(10 \mathrm{U} / \mathrm{ml}), 0.2 \%$ endothelial growth factor (egf) (21) and antibiotics. To deplete the EC-cultures from non-endothelial cells, cell sorting using Dil-AC-LDL as marker (as described previously [22]) was used.

For the adherence assay studies, the monolayers were grown on $15 \mathrm{~mm}$ thermanox coverslips (Lux, Miles Scientific, Naperville, USA) precoated with fibronectin, placed in the bottom of a 24-well tissue culture clusterplate (Costar, Cambridge, USA). These cells had gone through three to five population doublings after isolation, before they were used in the adherence assay.

Human embryonal fibroblasts (HEF) were cultured in Eagle's Minimum Essential Medium (MEM) supplemented with $10 \%$ inactivated (at $56^{\circ} \mathrm{C}$ for $30 \mathrm{~min}$ ) newborn calf serum (iNCS) and antibiotics.

Vero cells were cultured in roller-bottles in MEM supplemented with $10 \%$ iNCS, to confluency, and used for the preparation of the virus pool.

\subsubsection{Virus}

Herpes simplex virus type 1 (HSV-1) originally obtained from the American Type Culture Collection, was propagated in Vero cells. Cells were infected with HSV-1 at a multiplicity of infection (MOI) of 0.1 . Non-adsorbed virus was removed after $1 \mathrm{~h}$ at $37^{\circ} \mathrm{C}$ and fresh MEM, containing 5\% iFCS, was added. The supernatant containing $4 \times 10^{7}$ to $5 \times 10^{7}$ plaque forming units ( $\mathrm{pfu}$ ) per $\mathrm{ml}$ was harvested after an incubation period of 3 to 5 days and stored at $-70^{\circ} \mathrm{C}$. The titer was evaluated by plaque assay in Vero cells using the method described for rat cytomegalovirus (RCMV) (23).

\subsubsection{Infection of the endothelial cells}

Subconfluent HUVEC monolayers containing (2-4 × $10^{4}$ cells/coverslip) were used for the infection experiments; $24 \mathrm{~h}$ before the addition of virus, the growth medium was replaced by maintenance medium consisting of 50\% M 199 and 50\% RPMI 1640 (M 199/RPMI 1640) supplemented with $20 \%$ iFCS, $1 \%$ egf and antibiotics. HUVEC monolayers were 
infected with HSV-1 at a MOI of 10 or otherwise as indicated. After an incubation period of $60 \mathrm{~min}$, the monolayers were washed and maintenance medium was added. The cell cultures were incubated at $37^{\circ} \mathrm{C}$ for $3 \mathrm{~h}$ in a $\mathrm{CO}_{2}$ incubator and used for the MCadherence experiments. Non-infected cell monolayers were included as controls and were processed in a similar manner.

To determine whether infected monolayers released a factor that induced increased MC-adherence, HUVEC monolayers were incubated with HSV-1 for $1 \mathrm{~h}$ and $3 \mathrm{~h} \mathrm{p}$.i., the "supernatant medium" was collected, virus was removed by ultra-centrifugation for $1 \mathrm{~h}$ at $100,000 \mathrm{~g}$, and this medium was incubated with uninfected HUVEC monolayers, before determination of MC-adherence.

\subsubsection{Evaluation of the HSV-1 infection in HUVEC}

To determine morphological changes and the progression of the cytopathic effect by virus infection, endothelial cells were incubated with HSV-1 for 60 min, and after 2, 4, 8, 24, $48 \mathrm{~h} \mathrm{p}$.i., the monolayers were fixed and stained with haematoxyline/eosine or with acridine orange. Infected and non-infected HUVEC monolayers were examined simultaneously with a light microscope. The percentage of infected cells was determined by the direct immunofluorescence technique using phenyl-isothiocyanate (FITC) conjugated anti-HSV-1-monoclonal antibodies (obtained from Dr. ADME Osterhaus, State Institute of Public Health and Environmental Hygiene (RIVM), Bilthoven, The Netherlands). Infected and non-infected HUVEC monolayers were examined simultaneously with a fluorescence microscope equiped with the appropriate barrier filters.

\subsubsection{Isolation of monocytes}

Human monocytes (MC) were isolated from blood of normal donors using a modification of the method described by Koch (24). Briefly, the human mononuclear cells were isolated from the buffy coat prepared from $60-80 \mathrm{ml}$ blood containing acid citrate dextrose (ACD) by centrifugation ( $30 \mathrm{~min}, 400 \mathrm{~g}$, at room temperature) on a Ficoll-Hypaque gradient (Pharmacia, Uppsala, Sweden). These mononuclear cells were then fractionated by centrifugation on a discontinuous percoll gradient (Pharmacia, Uppsala, Sweden): the mononuclear cells $\left(1.5 \times 10^{8}\right)$ were suspended in $3 \mathrm{ml}$ of $60 \%$ percoll solution and dispended on a $100 \%$ percoll solution into a $15 \mathrm{ml}$ centrifuge tube. The gradient was constructed by layering $3 \mathrm{ml}$ volumes of percoll in diminishing concentrations on top of the $60 \%$ percoll solution. The tubes were centrifuged for $30 \mathrm{~min}$ at $4{ }^{\circ} \mathrm{C}$ using $700 \mathrm{~g}$ in a Beckman centrifuge. MC were harvested with a siliconized pasteur pipet from the $40 \% 150 \%$ layer interface and from the $50 \% 154 \%$ percoll interface, washed once after dilution with HEPES buffered Hanks balanced salt medium (HBSS-HEPES) supplemented with $1 \%$ inactivated FCS, and counted. Viability was determined by counting the percentage of cells that excluded trypan blue and was consistently found to be $>99 \%$. The purity of harvested MC was assessed by morphology as well as by non-specific esterase staining. Greater than $80 \%$ of the cells were judged to be MC by morphology and 
by positive staining with non-specific esterase (Lawrence $e t a l$. [25] and Tucker $e t$ al. [26]).

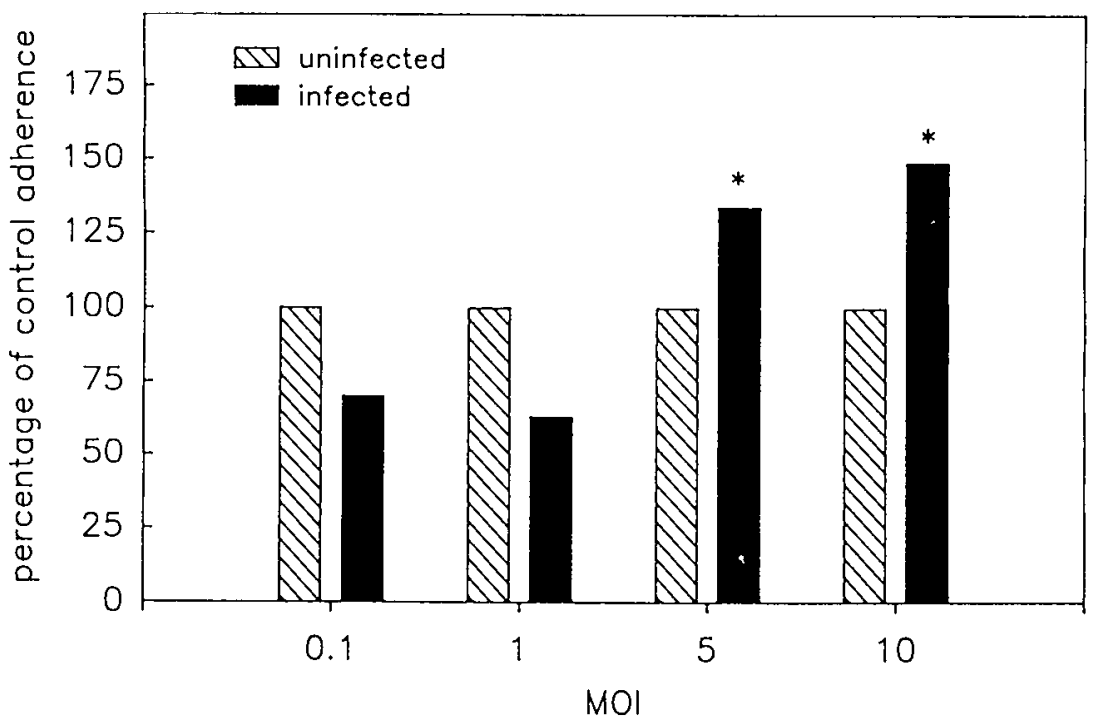

fig. 1: Adherence of MC 10 infected HUVEC with different virus concentrations (MOI 0.1, 1, 5 and 10) after $3 \mathrm{~h}$ p.i. The MC adherence to infected HUVEC with regard to control adherence is expressed as percentage of control adherence. *: the p-value indicated above the bars were signifcant $(p \leq 0.0001)$.

\subsubsection{Adherence assay}

To test the capacity of MC to adhere to HSV-1-infected HUVEC, $4 \times 10^{4}$ HUVEC plated on thermanox coverslips coated with $0.01 \%$ fibroncetin, and grown to confluency over the course of 2 or 3 days, were infected with HSV-1. At 3 h p.i. the medium was removed and the cells were washed twice in HBSS-HEPES supplemented with $1 \%$ heat-inactivated FCS (iFCS). A suspension of MC $\left(0.5 \mathrm{ml}\right.$ containing $10^{5}$ cell $\left./ \mathrm{ml}\right)$ in HBSS-HEPES supplemented with $1 \%$ iFCS was gently pipetted onto HSV-1-infected monolayers and incubated for $15 \mathrm{~min}$ in a $\mathrm{CO}_{2}$-incubator at $37^{\circ} \mathrm{C}$, without agitation. At the end of the incubation period, the coverslips were carefully rinsed by passing 5 times through an airphosphate buffered saline ( $\mathrm{pH}$ 7.2) interface, and air dried. The number of cells which remained attached to the HUVEC monolayer after the washing procedure were referred to as adherent cells. 
Adherent cells were counted after fixation in aceton-monofix and identified by non-specific esterase $(25,26)$ and methylgreen staining. The adherence is expressed as the ratio of number of MC per number of HUVEC per unit area for each coverslip. All experiments were performed on at least three separate occasions.

\subsubsection{Statistics}

The adherence (mean \pm SEM) was determined for each group of experiments. In each experiment, in 30 to 40 microscopic areas the number of HUVEC and the number of MC were counted, and the result is expressed as the following ratio: number of $\mathrm{MC} /$ number of HUVEC per unit area for non-infected- and HSV-1-infected HUVEC. To test the effect of virus inoculation on MC-adherence to HUVEC we used the Wilcoxon test. If the p-value was $\leq 0.05$, the difference between the values was determined to be significant.

\subsection{RESULTS}

\subsubsection{HSV-1 infection of HUVEC}

Preliminary studies of HSV-1 replication in HUVEC monolayers were conducted to determine the optimal time for the adherence assay.

HSV antigen was first detected by immunofluorescence between 3 and $8 \mathrm{~h} \mathrm{p}$.i. At the time of the earliest detectable fluorescence, about $20 \%$ of the cells showed a bright staining in the nucleus. Cytopathological changes were visualized by light microscopy as early as 4 to $8 \mathrm{~h}$. These changes were limited to differences in the size and shape of cells. At this time all cells remained alive and no cell loss could be observed. More characteristic morphological changes consisting of grape-like clusters of round highly refractile cells and giant polykaryocytes were detected at $24 \mathrm{~h}$ and at $48 \mathrm{~h}$; the infected monolayers began to detach from the surface. In the supernatant of the infected HUVEC, infectious virus was detectable at $24 \mathrm{~h}$ p.i.

\subsubsection{Effect of HSV-1 infection on the adherence of monocytes}

To investigate whether HSV-1 infection of HUVEC has an effect on the adherence of MC to the cell monolayer, the HUVEC monolayers were infected using different concentrations of virus (MOI 0.1, 1, 5 and 10). The number of MC that adhered to HSV1 -infected HUVEC was compared with number of MC adherent on non-infected HUVEC.

As shown in fig. 1, HSV-1 infection resulted in an increase of the adherence of MC to the HUVEC when MOI of 5 or 10 were used. The MC-adherent to infected cells increased to $132-149 \%$ of the control adherence. In contrast when low concentrations of virus (MOI 0.1 or 1 ) were used, no enhanced adherence could be observed. To determine the optimal number of MC required for the adherence assay on HSV-1-infected cells, two different numbers of cells were tested using ratios: number of MC/number of HUVEC of 5 and 10. As depicted in fig.2, both ratios gave a significant increased MC adherence on HSV-1- 
infected HUVEC monolayers, but the background adherence at the ratio of 5 was lower than the background adherence at the ratio of 10 .

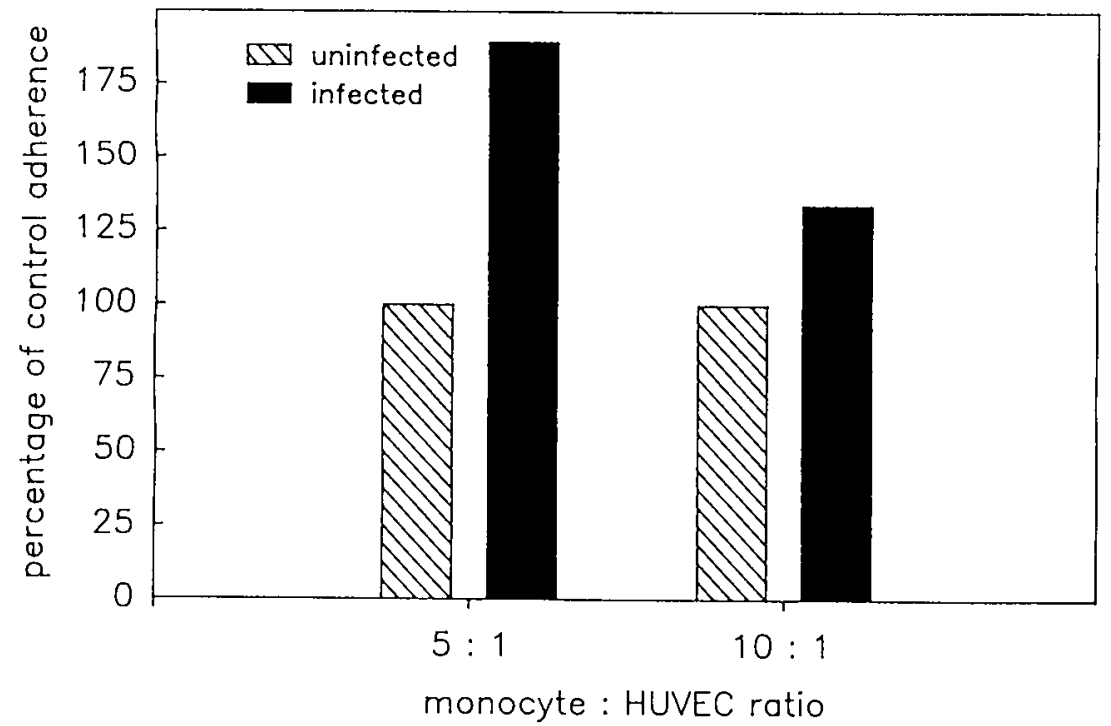

fig. 2: Adherence of MC to infected HUVEC (MOI 10) monolayers after $3 \mathrm{~h}$ p.i. using ratio number of $\mathrm{MC}$ /number of HUVEC of 5 and 10. The MC adherence to infected HUVEC with regard to control adherence is expressed as percentage of control adherence. *: the p-value indicated above the bars were significant $(p \leq 0.0001)$.

\subsubsection{Effect of supernatant of HSV-1-infected cells on the adherence of MC to HUVEC}

To investigate whether the increased MC adherence to HSV-1-infected HUVEC is the result of a direct virus effect or the result of an indirect effect (by the induction of soluble products that induce an increase in the adherence), the supernatants of virus infected HUVEC were used. Non-infected endothelial monolayers were incubated with "supernatant medium" obtained from infected HUVEC. Two batches of HUVEC monolayers were used. One batch was incubated for $1 \mathrm{~h}$ with "supernatant medium", after $1 \mathrm{~h}$ the "supernatant medium" was removed and $0.5 \mathrm{ml}$ infection medium was added and the monolayers were further incubated for $3 \mathrm{~h}$. Thereafter, $\mathrm{MC}$ were added, incubated for $15 \mathrm{~min}$ and the $\mathrm{MC}$ adherence was determined. The other batch was incubated for $4 \mathrm{~h}$ with "supernatant medium", and directly used in the MC adherence assay after washing. 


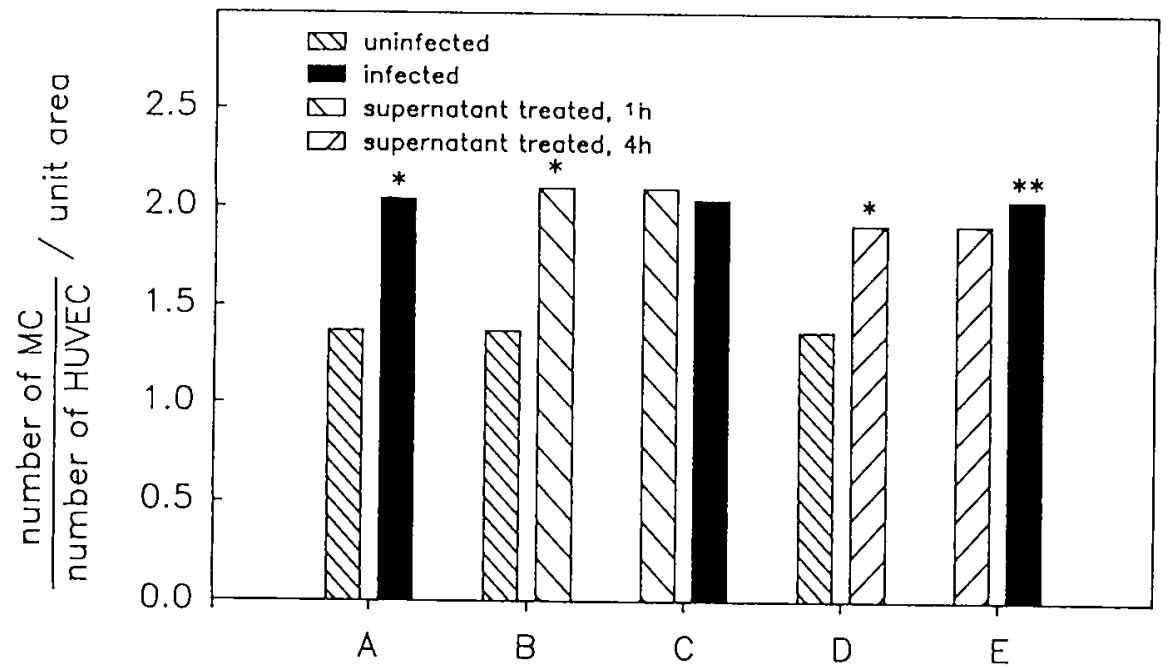

fig.3: Effect of the supernatant incubation (sup.-treated) derived from infected HUVEC monolayers on the $M C$ adherence to non-infected HUVEC monolayers after $3 \mathrm{~h} \mathrm{p.i.} \mathrm{or} 4 \mathrm{~h}$ incubation. A: comparison of $\mathrm{MC}$ adhesion to uninfected and infected HUVEC $\left(\begin{array}{ll}1 & h\end{array} 3 \mathrm{~h}\right.$ p.i. B: comparison of MC adhesion to uninfected and infected HUVEC ( 1 h) $3 \mathrm{~h}$ p.i. C: comparison of MC adhesion to sup.-treated and infected HUVEC (1 h) 3 h p.i. D: comparison of MC adhesion to uninfected and sup.-treated HUVEC (4h). E: comparison of MC adhesion to sup.-treated $(4 \mathrm{~h})$ and infected HUVEC $(1 \mathrm{~h}) 3 \mathrm{~h}$ p.i. The MC adherence to HUVEC monolayer is expressed as number of $\mathrm{MC} /$ number of HUVEC per unit area. *: p-value indicated above the bars were significant $(p \leq 0.001)$.**: $p$-value indicated above the bars were significant $(p \leq 0.05)$.

These data (see fig.3) indicated that HSV-1 infection of HUVEC induced the production and/or release of an adherence stimulating factor in the supernatant. This factor has the capacity to induce an increased adherence of MC to HUVEC after a short incubation period ( 1 till $4 \mathrm{~h}$ ). Since HSV-1 is able to infect HEF as well as HUVEC, it may be possible that HSV-1 infection leads to the induction of the adherence stimulating factor in both cell types. Therefore we tested the effect of the "supernatant medium" of HSV-1-infected HEF on the induction of an increased adherence of $\mathrm{MC}$ to uninfected HUVEC. As can be seen in fig.4, the supernatants from both HSV-1-infected HEF and HSV-1-infected HUVEC (fig.3) have the capacity to induce an enhanced MC adherence to uninfected HUVEC. The kinetics of the appearance of an increased adherence did not differ for the supernatants obtained from HSV-1-infected HEF or HSV-1-infected HUVEC. 


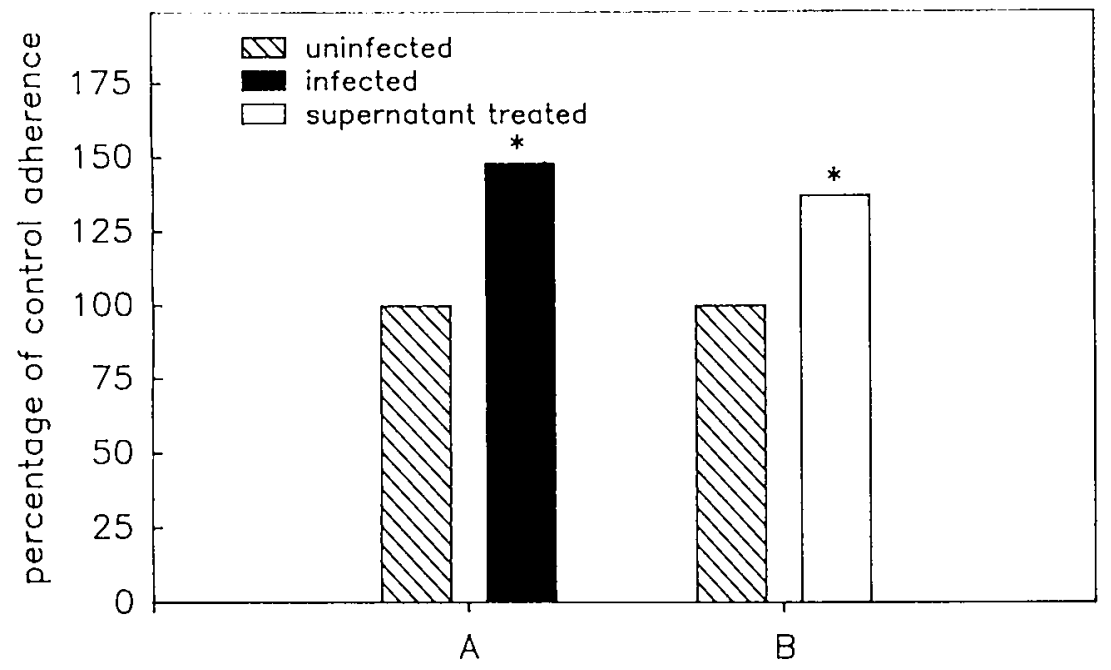

fig. 4: Effect of the supernatant of HEF infected cells on the adherence of MC to HUVEC.

Adherence of MC to infected HUVEC (A) and to supernatant treated HUVEC (B) after $3 \mathrm{~h}$ p.i. is expressed as percentage of control adherence (uninfected). *: p-value indicated above the bars were significant $(\mathrm{p} \leq 0.0001)$.

\subsubsection{Effect of tunicamycin on the virus induced enhancement of the MC-adherence}

To determine whether the enhanced adherence of MC to HSV-1-infected HUVEC is the result of the appearance of glycoproteins on the surface of the HUVEC, we tested the effect of tunicamycin treatment on the adherence of MC. HSV-1-infected HUVEC were treated with 1 to $3 \mu \mathrm{g} / \mathrm{ml}$ tunicamycin at the time of HSV-1 inoculation. Controls, consisted of either non-infected HUVEC monolayers, treated with 1 to $3 \mu \mathrm{g} / \mathrm{ml}$ tunicamycin, or untreated HSV-1-infected HUVEC monolayers, were used. As shown in fig.5, after tunicamycin treatment of the HSV-1-infected HUVEC, no increase in the adherence of $\mathrm{MC}$ could be observed, indicating that the adherence of $\mathrm{MC}$ on infected HUVEC is the result of the expression of glycoproteins on the membranes of HUVEC. 


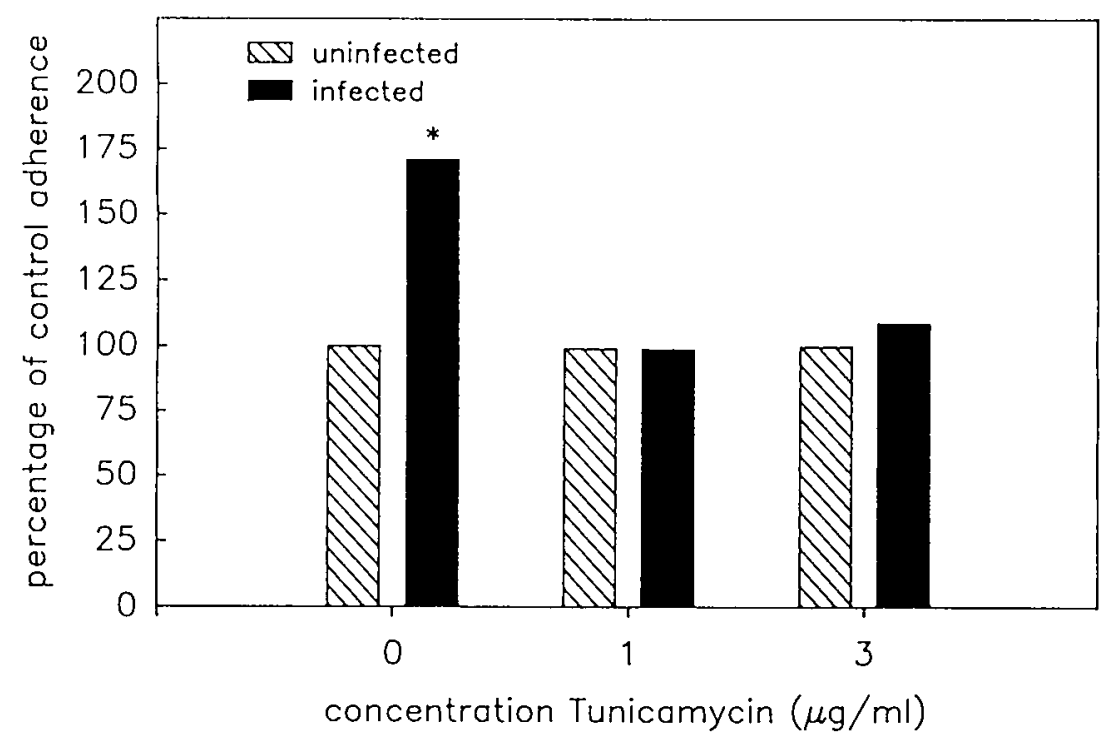

fig.5: Effect of tunicamycin in the virus induced enhancement of the MC adherence.

MC adherence to infected HUVEC- and non-infected HUVEC monolayers was measured after treatment with 1 and $3 \mu \mathrm{g} / \mathrm{ml}$ tunicamycin. *: $\mathrm{p}$-value indicated above the bars were significant $(\mathrm{p} \leq 0.0001)$.

\subsection{DISCUSSION}

We have demonstrated that infection of HUVEC with HSV-1 resulted in an increased adherence of $\mathrm{MC}$ which occured at $3 \mathrm{~h}$ p.i. when about $20 \%$ of the monolayer is infected and when there is no cytophatic effect observable in the monolayer. The adherence of human MC to virus-infected HUVEC monolayers proved to be effective and reproducible if a MOI of 5 or 10 (fig.1) and a ratio of number of MC/number of HUVEC of 5 (fig.2) was used.

A possible mechanism responsible for the enhanced MC adherence could be the expression of viral antigens on the surface of infected cells, but in addition, the supernatant derived from infected cells induced an enhancement of $\mathrm{MC}$ adherence, suggesting that other mechanisms are involved. Another mechanism could be that viral antigen reacting with antibody activates the complement resulting in a increased adherence, but, in all experiments used in this study, medium contained heat-inactivated FCS, suggesting that complement activation is not involved in the increase. 
Infection appears to stimulate the endothelium to release a soluble factor that promotes the MC adherence to non-infected endothelium. The production of this "adherence promoting factor" is not cell-specific. "Supernatant medium" derived from both infected HEF monolayers and HUVEC monolayers were able to stimulate $\mathrm{MC}$ adherence to noninfected HUVEC. The modulating factors responsible for increased $\mathrm{MC}$ adherence have not been defined yet. A possible mediator produced by endothelial cells, which could be considered to be "the adherence stimulating factor" is interleukin-1 (IL-1). Goerdt et al. (27) showed that EC activation by IL-1 resulted in an increased MC adhesion and similar results were found by Häyry $e t a l$. in rats (28). This enhanced MC adherence is mediated by the IL-1 induced synthesis of EC membrane receptors for the GP150 (CDw 18) adhesion glycoprotein of the MC (29-31). Other possibilities of enhancing factors are prostaglandins $(32,33)$ and platelet activating factor (PAF) (34), which are synthesized by HUVEC in culture.

The augmentation of $\mathrm{MC}$ adherence to infected endothelium was sensitive to tunicamycin treatment, in contrast to control $\mathrm{MC}$ adherence which was not inhibited. The tunicamycin group of antibiotics inhibits the incorporation of mannose into glycoproteins (35) in a wide variety of cell types, which is why tunicamycin has been widely used to study the role of the carbohydrate portion of glycoproteins in such phenomena as the secretion of proteins, membrane insertion and receptor activity. In our experiments a concentration of $1 \mu \mathrm{g} / \mathrm{ml}$ was sufficient to inhibit the expression of viral glycoproteins and/or viral induced glycoproteins on EC. We concluded from our experiments that MC adherence is probably mediated by glycoproteins expressed on the HUVEC membranes by virus infection but which receptors are responsible for the $\mathrm{MC}$ adherence is not known yet. Possible candidate molecules are $\mathrm{F}_{\mathrm{c}}$ and/or $\mathrm{C}_{3}(36,37)$ receptors on $\mathrm{EC}$, which are increased after virus infection (38), and/or fibronectin, which also increased after injury (39).

Taken together, these data indicate that enhanced MC adherence induced by virus itself and/or by virus induced soluble compounds, is mediated by the expression of glycoproteins on the membrane of treated HUVEC. The exact mechanism of interaction between human MC and HUVEC is not known yet, and deserves further study.

\subsection{ACKNOWLEDGEMENTS}

The authors wish to thank Mr. W. Mullers and Mr. W. Debie for their excellent technical assistance and Mrs. F. Claus-Hahn for preparation of the manuscript.

\subsection{REFERENCES}

1. Ross, R.: The pathogenesis of atherosclerosis - an update. N. Engl. J. Med. 314, 488-500 (1986).

2. Gimbrone, M.A. Jr.: Vascular endothelium and atherosclerosis. In: Moore, S. (ed.), Vascular injury and atherosclerosis, 25-52. New York: Marcel Dekker 1981.

3. Minick, C.R., Stemerman, M.B., Insull, W. Jr.: Effect of regenerated endothelium on lipid accumulation in the arterial wall. Proc. Natl. Acad. Sci. 74, 1724-1728 (1977). 
4. Sharma, H.M., Geer, J.C.: Experimental aortic lesions of acute serum sickness in rabbits. Am. J. Path. 88, 255-266 (1977).

5. Harker, L.A., Slichter, S.J., Scott, C.R., Ross, R.: Homocystinemia: Vascular injury and arterial thrombosis. N. Engl. J. Med. 291, 537-543 (1974).

6. Fabricant, C.G., Fabricant, J., Litrenta, M.M., Minick, C.R.: Virus induced atherosclerosis. J. Exp. Med. 148, 335-340 (1978).

7. Hajjar, D.P., Fabricant, C.G., Minick, C.R., Fabricant, J.: Virus-induced atherosclerosis. Herpesvirus infection alters aortic cholesterol metabolism and accumulation. Am. J. Path. 122, 62-70 (1986).

8. Minick, C.R., Fabricant, C.G., Fabricant, J., Litrenta, M.M.: Atherosclerosis induced by infection with a herpesvirus. Am. J. Path. 96, 673-706 (1979).

9. Gyorkey, F., Mulnick, L., Guinn, G.A., Gyorkey, P., Debakey, M.E.: Herpesviridae in the endothelial and smooth muscle cells of the proximal aorta in arteriosclerotic patients. Exp. Mol. Pathol. 40, 328-339 (1984).

10. Melnick, J.L., Petrie, B.L., Dreesman, G.R., Burek, J., McCollum, G.H., Debakey, M.E.: Cytomegalovirus antigen within human arterial smooth muscle cells. Lancet 2, 644-647 (1983).

11. Benditt, E.P., Barrett, T., McDougall, J.K.: Viruses in the etiology of atherosclerosis. Proc. Natl. Acad. Sci. USA 80, 6386-6389 (1983).

12. Adam, E., Probtsfield, J..L, Burek, J., McCollum ,C.H., Melnick ,J.L., Petrie, B.L., Bailey ,K.R., Debakey, M.E.: High levels of cytomegalovirus antibody in patients requiring vascular surgery for atherosclerosis. Lancet 8, 291-293 (1987).

13. Taylor, R.G., Lewis, J.C.: Endothelial cell proliferation and monocyte adhesion to atherosclerotic lesions of white carneau pigeons. Am. J. Path. 125, 152-160 (1986).

14. Camussi, G., Baglioni, C.: Tumor necrosis factor-cechectin stimulates peritoneal macrophages, polymorphonuclear neutrophils, and vascular endothelial cells to synthesize and release platelet-activating factor. J. Exp. Med. 166, 1390-1403 (1987).

15. Bussolino, F., Breviario, F., Tetta, C., Aglietta, M., Mantovani, A., Dejana, E.: Interleukin I stimulates platelet-activating factor production in cultured human endothelial cells. J. Clin. Invest. 77, 2027-2033 (1986).

16. Luchesi, B.R., Mickelson, J.K., Honeister, J.W., Jackson, C.V.: Interaction of the formed elements of blood with the coronary vasculature in vivo. Fed. Proc. 46, 63-72 (1987).

17. Bevilacqua, M.P., Pober, J.S., Wheeler, M.E., Cotran, R.S., Gimbrone, M.A.: Interleukin 1 acts on cultured human vascular endothelium to increase the adhesion of polymorphonuclear leukocytes, monocytes, and related leukocyte cell lines. J. Clin. Invest. 76, 2003-2011 (1985).

18. MacGregor, R.R., Friedman, H.M., Macarar, E.J., Kefalides, N.A.: Virus infection of endothelial cells increases granulocytic adherence. J. Clin. Invest. 65, 1469-1477 (1980).

19. Harker, L.A.: Platelets, endothelial injury, and atherosclerosis. In: Steinberg, D., Olefsky, J.M. (eds.), Contemporary issues in atherosclerosis, 25-52. Edinburgh, New York: Churchill Livingstone 1986.

20. Harlan, J.M., Harker, L.A.: Thrombosis and coronary artery disease. Current Concepts. Kalamazoo: Upjohn 1983.

21. Maciag, T., Cerundolo, I., Ilsley, S., Kelley, P.R., Foriand, R.: An endothelial cell growth factor from bovine hypothalamus: Identification an partial characterization. Proc. Nat. Acad. Sci. USA 76, 56745678 (1979).

22. Bruggeman, C.A., Debie, W.H.M., Muller, A.D., Schutte, B., Dam-Mieras, M.C.E. van: Cytomegalovirus alters the von Willebrand factor content in human endothelial cells. Thrombosis and Haemostasis 59, 264-268 (1988).

23. Bruggeman, C.A., Debie, W.H.M., Grauls, G., Boven, C.P.A. van: Cytomegalovirus infection of rat endothelial cells in vitro. Arch. Virol. 87, 265-272 (1986).

24. Koch, A.E., Polverini, P.J., Leibovich, S.J.: Induction of neovascularization by activated human monocytes. J. Leukoc. Biol. 39, 223-238 (1986).

25. Lawrence, C., Grossman, R.: Simple butyrate esterase stain for monocytes. Stain technology. 54, 321$323(1980)$.

26. Tucker, S.B., Pierre, R.V., Jordon, R.E.: Rapid identification of monocytes in a mixed mononuclear cell preparation. J. Immunol. Methods. 14, 267-269 (1977). 
27. Goerdt, S., Zwadlo, G., Schegel, R., Hagemeier, H.M., Sorg, C.: Characterization and expression kinetics of an endothelial cell activation antigen present in vivo only in acute inflammatory tissues. Exp. Cell. Biol. 55, 117-126 (1987).

28. Häyry, P., Leszezynski, D., Paavonen, T., Nemlander, A., Meide, P. van de, Schellekens, H.: Leukocyte binding and Ia-expression in vascular endothelium. Transpl. Proc. 14, $42-43$ (1987).

29. Zimmerman, G.A., McIntyre, T.M.: Neutrophil adherence to human endothelium in vitro occurs by CDw 18 (MO1, MAC-1/LFA-1/GP 150,95) glycoprotein-dependent and -independent mechanisms. J. Clin. Invest. 81, 531-537 (1988).

30. Te Velde, A.A., Keizer, G.D., Figdor, C.G.: Differential function of LFA-1 family molecules (CD11 and CD18) in adhesion of human monocytes to melanoma and endothelial cells. Immunol. 61, 261-267 (1987).

31. Mentzer, S.J., Crimmins, M.A.V., Burakoff, S.J., Faller, D.V.: Alpha and beta subunits of the LFA-1 membrane molecule are involved in human monocyte-endothelial cell adhesion. J. Cell. Physiol. 130, 410-415 (1987).

32. Gordon, J.L., Pearson, J.D.: Effects of sulphinpyrazon and asparin on prostacyclin synthesis by endothelial cells. Br. J. Pharmac. 64, 481-483 (1978).

33. Pearson, J.D., Carleton, J.S., Beesley, J.E., Hutchings, A., Gordon, J.L.: Granulocyte adhesion to endothelium in culture. J. Cell. Sci. 38, 225-235 (1979).

34. Whatley, R.E., Zimmerman, G.A., McIntyre, T.M., Taylor, R., Prescott, S.M.: Production of plateletactivating factor by endothelial cells. Seminars in thrombosis and hemostasis 13, 445-453 (1987).

35. Keenan, R.W., Hamill, R.L., Occolowitz, J.L., Elbein, A.D.: Biological activities of isolated tunicamicin and streptovinudin fractions. Biochem. 20, 2968-2973 (1981).

36. Para, M.F., Baucke, R.B., Spear, P.G.: Glycoprotein gE of Herpes Simplex Virus type 1: effects of anti-gE on virion infectivity and on virus-induced Fc receptors. J. Virol. 41, 129-136 (1982).

37. Friedman, H.M.: Viral infection of endothelium and induction of $F \mathrm{c}$ and $\mathrm{C} 3$ receptors. In: Jaffe, E.A. (ed.), Biology of endothelial cells, 268-276. Boston: Martinus Nijhoff 1984.

38. Cines, D.B., Lyss, A.P., Bina, M., Corkey, R., Kefalides, N.A., Friedman, H.M.: Fe and C3 receptors induced by Herpes Simplex Virus on cultured human endothelial cells. J. Clin. Invest. 69, 123128 (1982).

39. Clark, R.A.F., Quinn, J.H., Winn, H.J., Lanigan, J.M., Dellepella, P., Colvin, R.B.: Fibronectin is produced by blood vessels in response to injury. J. Exp. Med. 156, 646-651 (1982). 
CHAPTER VI

THE EFFECT OF CYTOMEGALOVIRUS INFECTION ON THE ADHERENCE OF POLYMORPHONUCLEAR LEUKOCYTES TO ENDOTHELIAL CELLS

* Span AHM, van Boven CPA, Bruggeman CA

European Journal of Clinical Investigation 19: 542, 1989 


\begin{abstract}
Adherence of polymorphonuclear leukocytes (PMN) to the endothelial lining of blood vessels is an essential component of the inflammatory response. We have examined the effect of cytomegalovirus (CMV) infection on the adherence of PMNs using an in vitro model system.

Human umbilical veneous endothelial cells (HUVEC) were grown on fibronectin coated plastics. CMV infection of HUVEC resulted in the appearance of viral antigens in a small percentage of the cells. At 24 hours post infection when no virus induced cytopathic effect could be observed in the cell monolayers, the adherence of PMNs was significantly increased. The virus induced adherence effect was cell bound and could not be induced by soluble components in the medium of the virus infected cells. The augmentation of the PMN adherence to CMV infected endothelium was sensitive to tunicamycin suggesting that the virus infection induces the expression of glycoproteins on the HUVEC membranes which are responsible for the PMN adherence.

Thus CMV infection of the endothelium results in an increased adherence of PMNs. In the in vivo situation systemic viral infection potentially can lead to infection of blood vessel endothelium and thus can induce a damage of endothelium. This phenomenon could play a role in the atherogenesis process.
\end{abstract}




\subsection{INTRODUCTION}

The presence of cytomegalovirus (CMV) in endothelial cells in vivo has been described by Myerson et al. (1). They studied two cases of disseminated CMV infection in bone marrow transplant recipients and detected virus DNA and viral antigens in endothelial cells. Bamji (2) reported 2 cases of vasculitis with CMV inclusion bodies present in the capillary endothelial cells. The presence of CMV in the endothelium in humans was confirmed in the mouse model (3). The role of CMV infection of endothelial cells in the pathogenesis of arterial wall injury is still unknown. Starting from this subject we started the study of the CMV infection of endothelial cells in vitro. We infected endothelial cell monolayers in vitro and found that the infection resulted in the appearance of CMV antigens in the nuclei of about $10 \%$ of the endothelial cells, in the disappearance of the von Willebrand Factor (vWF) from the infected cells (4), in an increase in surface expression of endothelial cell procoagulant activity (5), and in an enhanced monocyte adherence to the infected cell monolayer.

It has been proposed that advanced atherosclerotic lesions in human is a result from the respons of smooth muscle cells to injury of endothelial lining of the vessel. Because it has been shown that CMV can be detected in endothelial cells in vivo a possible role of CMV and of other herpesvirus infection in the pathogenesis of atherosclerosis has been suggested.

Recent reports have supported this role of CMV in the etiology of atherosclerosis in humans. The virus has been found in atherosclerotic plaques $(6,7)$ and, in addition, a correlation between the presence of atherosclerosis and antibodies against CMV confirmed also the suggestion of a possible role of this virus in the development of atherosclerosis (8).

Irrespective of the precise nature of the mechanism of virus induced atherosclerosis, the earliest event associated with endothelial cell damage is an enhanced adherence of leukocytes to the endothelium (9). Using in vitro infection models several investigators have demonstrated that the adherence of granulocytes to endothelium was increased by viral infection $(10,11)$. Because of our interest in the early stages of atherosclerosis and the role of virus infection in this process we have studied the effect of CMV infection of endothelial monolayers on the subsequent adherence of polymorphonuclear leukocytes.

\subsection{MATERIALS AND METHODS}

\subsubsection{Cell cultures}

Human endothelial cells (HUVEC) were harvested from umbilical veins by exposing the lumen of the vessel to $0.125 \%(\mathrm{v} / \mathrm{v})$ trypsin for $20 \mathrm{~min}$. The cells were cultured in fibronectin $(0.01 \%)$ precoated $8 \mathrm{~cm}$ wells in growth medium consisting of $50 \%$ medium 199 (M199) and 50\% RPMI 1640 (RPMI 1640) supplemented with $20 \%$ fetal calf serum (FCS), heparin $(10 \mathrm{U} / \mathrm{ml}), 0.2 \%$ endothelial growth factor (egf) (12) and antibiotics. To deplete the endothelial cell cultures from non endothelial cells, cell sorting using DilAC-LDL as marker as described previously (4) was used. 
For the adherence assay studies, the monolayers were subcultured on $15 \mathrm{~mm}$ Thermanox coverslips (LUX, Miles Scientific, Naperville, USA) precoated with fibronectin, placed in the bottoms of a 24-well tissue culture clusterplate (Costar, Cambridge USA). The cells had gone through three to five doublings after isolation, before they were used in the adherence assay.

Human embryonal fibroblasts (HEF) were cultured in Eagle's minimal essential medium (MEM) supplemented with $10 \%$ heat inactivated newborn calf serum (NCS) and antibiotics. For the preparation of the virus pool confluent HEF monolayers were used.

\subsubsection{Virus}

The Kerr strain of Cytomegalovirus (CMV), obtained from Dr. H.T. Weiland, Lab. Virology, University Leiden, The Netherlands, was used. Pools of cell culture passaged CMV, prepared by infecting HEF monolayers, were used.

The infectivity of the CMV pool was determined by plaque assay in fibroblasts as described previously for rat CMV (13).

\subsubsection{Viral inoculation of the cell monolayer}

HUVEC monolayers, near to confluency (containing $2-4 \times 10^{4}$ cells/coverslip) were used for the infection experiments. Twenty four hours before infection the growth medium was removed, the cells were washed once with maintenance medium, and incubated further with this medium, consisting of 50\% M199 and 50\% RPMI 1640 supplemented with 20\% heat inactivated FCS, $1 \%$ egf and antibiotics.

HUVEC monolayers were inoculated with the appropiate CMV pool at a multiplicity of infection (MOI) of 30 unless indicated otherwise. After 60 minutes incubation at $37^{\circ} \mathrm{C}$ and a centrifuge speed of $1500 \mathrm{~g}$ the maintenance medium was replaced and the HUVEC monolayers were incubated for another $24 \mathrm{~h}$ in a $\mathrm{CO} 2$ incubator and used for the polymorphonuclear leukocyte (PMN) adherence experiments.

Noninfected HUVEC monolayers were used as controls and were processed in a similar manner.

To determine whether infected monolayers released a factor that induced increased PMN adherence, HUVEC and HEF monolayers were incubated for $1 \mathrm{~h}$ with CMV. At 24h post infection (p.i.), the supernatant medium was collected, virus was removed by ultracentrifugation for 90 minutes at $110,000 \mathrm{~g}$. Noninfected HUVEC monolayers incubated with this medium for $60 \mathrm{~min}$ were used for the PMN adherence experiments as described further.

\subsubsection{Treatment of endothelial cells with tunicamycin}

HUVEC monolayers were infected with CMV as described above. In the infection medium tunicamycin (Sigma, St. Louis, U.S.A.) at a concentration of 1 or $3 \mu \mathrm{g} / \mathrm{ml}$ was added. At 
$24 \mathrm{~h}$ p.i. the adherence experiments were done as described above. Noninfected monolayers were used as controls and CMV infected monolayers without tunicamycin were included.

\subsubsection{Evaluation of the CMV infection in HUVEC}

To evaluate the CMV infection in HUVEC monolayers, cells were monitored for the appearance of a cytopathic effect (CPE) and virusproduction.

To determine the morphological changes, and the progression of the CPE, infectedand noninfected endothelial cell monolayers were fixed daily in $3 \%$ paraformaldehyde, treated with $0.1 \% \mathrm{NP} 40(15)$ and examined by microscopy.

For determination of the percentage of infected cells the indirect immunofluorescence method was used as described previously (4) using anti-CMV monoclonal H204 reacting with a 68kd nuclear antigen (dilution 1/50) and FITC-conjugated rabbit anti mouse gammaglobulin antiserum (dilution 1/25) (Dako, Denmark).

The number of cells showing intranuclear antigens was counted and was expressed as the percentage of the whole monolayer. The values are expressed as the mean of at least four separate countings. The monolayers were observed with a Zeiss-fluorescence microscope equipped with the appropriate barrier filters.

To determine the production of infectious virus, confluent monolayers infected with CMV, were examined for the presence of infectious virus in the cells and in the supernatant. For the detection of intracellular virus the cells were homogenized by sonication as described previously for rat CMV (13). At different days p.i. the virus titer was determined by plaque assay in HEF monolayers using the method described for rat CMV (13)

\subsubsection{Isolation of polymorphonuclear leukocytes (PMN)}

The human PMNs were isolated from blood using a modification of the method described by Verbrugh et al. (15).

Briefly, $60-80 \mathrm{ml}$ platelet deficient blood containing acid citrate dextrose (ACD) was centrifuged $250 \mathrm{~g}$ during $10 \mathrm{~min}$. in a Beckman centrifuge. The buffycoat was collected and resuspended in the autologous ACD-plasma. This suspension was mixed with $5 \%$ dextran T500 (Pharmacia, Uppsala, Sweden) solution in PBS (without $\mathrm{Ca}++$ and $\mathrm{Mg}++$ ) in a ratio of $10 \mathrm{ml}$ suspension to $3 \mathrm{ml}$ dextran solution. After a sedimentation time of 30 min under an angle of $30^{\circ} \mathrm{C}$ at roomtemperature, the supernatant was collected and centrifuged for $10 \mathrm{~min}$ at $200 \mathrm{~g}$. Next the pellet resuspended in cold HEPES-buffered Hanks balanced salt medium supplemented with $0.1 \%$ gelatin $(0.1 \%$ gelatin-HBSSHEPES) was dispended on cold Ficoll-Hypaque (Pharmacia, Uppsala, Sweden) in a $15 \mathrm{ml}$ polystyrene centrifuge tube, and centrifuged for 35 minutes, $600 \mathrm{~g}$ at $4^{\circ} \mathrm{C}$. This pellet was resuspended in cold lysisbuffer consisting of $10 \mathrm{mM} \mathrm{KHCO}$ and $15 \mathrm{mM} \mathrm{NH}_{4} \mathrm{Cl}$, and incubated for $10 \mathrm{~min}$ at $4^{\circ} \mathrm{C}$, washed twice, and resuspended in $0.1 \%$ gelatin-HBSSHEPES and counted. 
Viability was determined by counting the percentage of the cells that excluded trypan blue and was consistently found to be more than $95 \%$. The purity of harvested PMNs was assessed by morphology as well as by chloro-acetate esterase staining (16) and greater than $90 \%$ of the cells were judged to be PMNs.

\subsubsection{Adherence assay}

The capacity of the PMNs to adhere to CMV infected HUVEC, was performed using a modification of the adherence assay described previously for monocytes (17). Briefly, the PMNs suspended in $0.1 \%$ gelatin-HBSS-HEPES were incubated with CMV infected HUVEC monolayers at $24 \mathrm{~h}$ p.i. or otherwise as described for $15 \mathrm{~min}$ at $37^{\circ} \mathrm{C}$. The adhering cells were counted after fixation with a buffered formaline-aceton mixture and identified by chloro-acetate esterase (16) and methylgreen staining.

The adherence was expressed as the ratio of number of PMNs/ number of HUVEC per unit of area for each coverslip.

All experiments were performed on at least three separate occasions.

\subsubsection{Statistics}

The adherence (mean $\pm S D$ ) was determined for each group of experiments. In each experiment, the number of HUVEC and the number of PMNs were counted in 30 to 40 microscopic areas, and the result is expressed as the ratio: number of PMNs/number of HUVEC per unit area for noninfected-and CMV infected-HUVEC. To test the effect of virus infection on the PMN adherence the Wilcoxon test was used. If the p-value was $\leq 0.05$, the difference between the values was determined as being significant. 


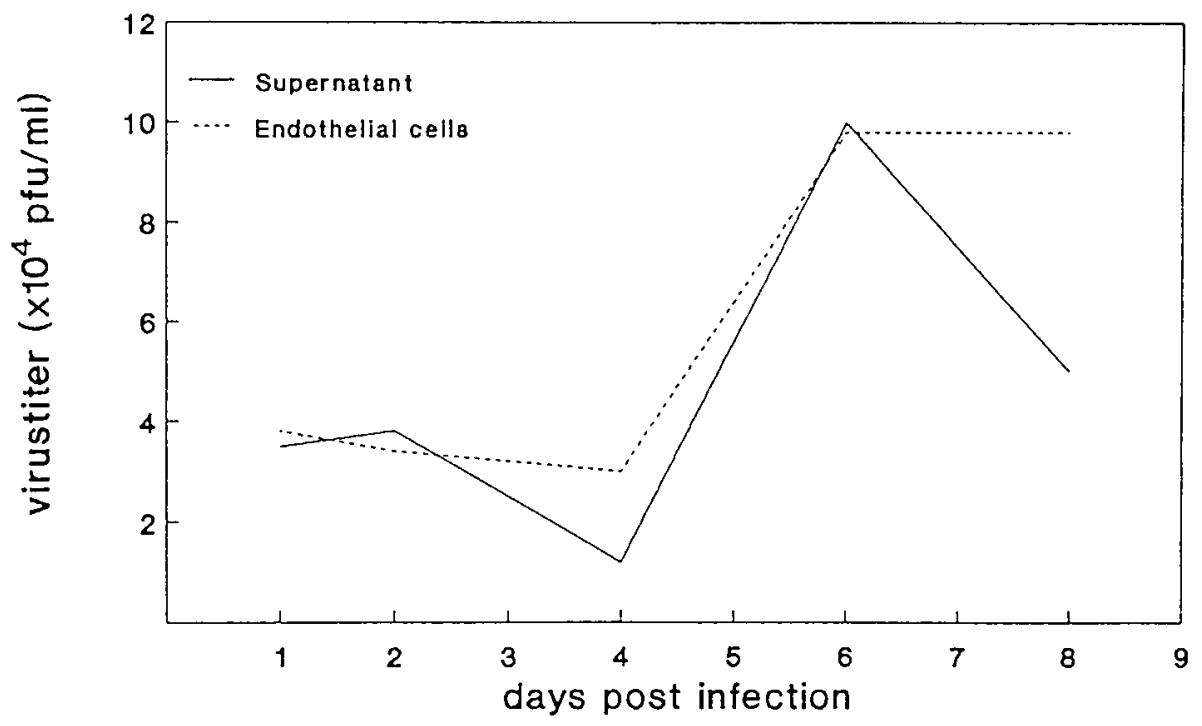

fig.1: Presence of infectious virus in the HUVEC and in the supernatant.

Confluent monolayers were infected with CMV at a MOI of 10. At different days post infection the cell monolayers were examined for the presence of infectious virus in the cells and in the supernatant. The titer was evaluated by plaque assay (13). The data shown represent the mean of 2 experiments.

\subsection{RESULTS}

\subsubsection{CMV infection of HUVEC}

To determine the optimal time for the adherence assay; CMV infection in HUVEC monolayers was observed for a period of one week using the indirect immunofluorescence technique. Incubation of HUVEC monolayers with CMV at a MOI of 10 resulted in the appearance of intranuclear CMV antigens at day 1 post infection in $10-15 \%$ of the cells. In these cells no CPE was observed. At day 4 and 7 p.i. the number of infected cells was not increased but there was a significant increase in the intensity of the fluorescence. In these cells a typical CMV-CPE appeared, showing enlarged nuclei. In the cells and in the supernatant an increase in the amount of infectious virus could be detected between day 5 and 8 p.i. (fig.1) 


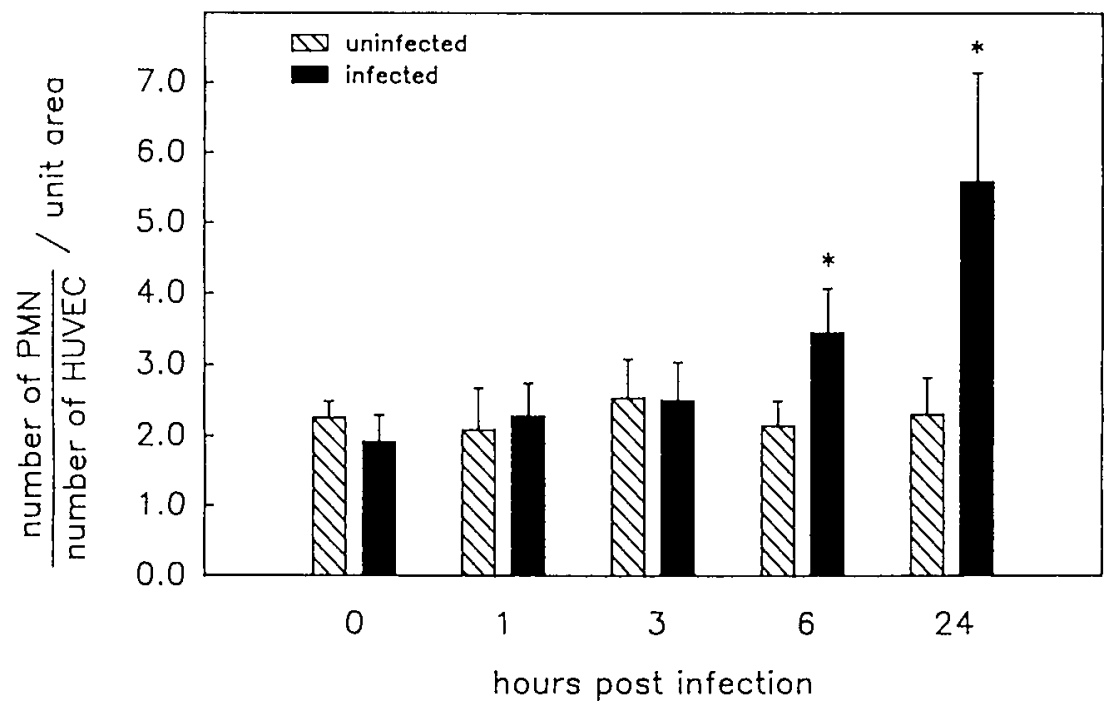

fig.2: Adherence of PMNs to CMV infected HUVEC monolayers at different intervals (h) p.i. The adherence to the endothelial cells is expressed as the ratio of number of PMNs/number of HUVEC per unit area. * $p$-value indicated above the bars are significant $(p \leq 0.001)$.

\subsubsection{Effect of CMV infection on the adherence of PMNs}

To investigate whether CMV infection of HUVEC has an effect on the adherence of PMNs to the cell monolayer, the HUVEC monolayers were infected using a MOI of at least 30 .

To determine the optimal time post infection required for the adherence assay on CMV infected cells, the adherence was measured at $0,1,3,6$ and $24 \mathrm{~h}$ p.i. No significant increase in adherence to CMV infected cells was seen at $3 \mathrm{~h}$ p.i., but beginning at $6 \mathrm{~h}$ a significant increase was detected. The maximal effect was obtained at $24 \mathrm{~h}$ p.i. (fig.2). So an incubation time of $24 \mathrm{~h} \mathrm{p.i.} \mathrm{was} \mathrm{chosen} \mathrm{for} \mathrm{subsequent} \mathrm{experiments} \mathrm{to} \mathrm{maximize} \mathrm{the}$ increase seen in PMN adherence, while avoiding the monolayer disruption that occured with a longer infection time. The number of PMNs that adhered to CMV infected HUVEC was compared with the number of PMNs adherent on noninfected HUVEC. As can be seen in fig. 3 a significant increase in the PMN adherence was observed in virus infected HUVEC compared to noninfected cells ( $\mathrm{p} \leq 0.001)$.

The enhancement in PMN adherence increased to an average of $500 \%$ of the control adherence. 


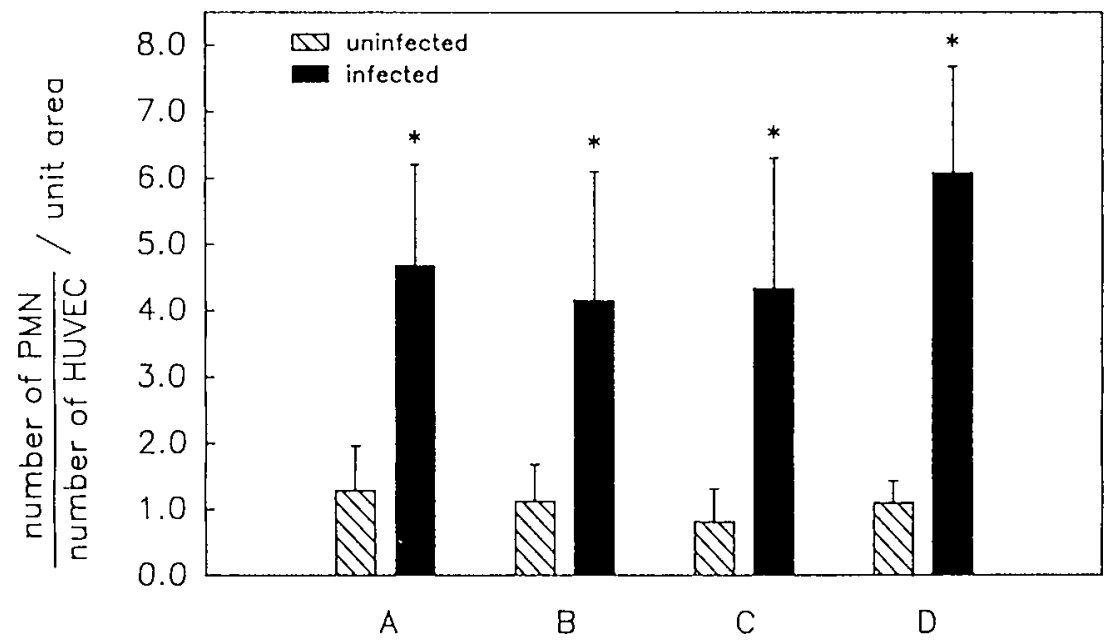

fig. 3: Adherence of PMNs to CMV infected HUVEC monolayers at $24 \mathrm{~h}$ p.i., determined in 4 separate experiments. The adherence to the HUVEC monolayers is expressed as the ratio of number of PMNs/number of HUVEC per unit of area. Each bar expressed the mean of 40 areas. * p-value indicated above the bars are significant $(p \leq 0.001)$.

\subsubsection{The effect of supernatant of CMV infected cells on the adherence of PMNs to HUVEC}

To investigate whether the increased PMN adherence to CMV infected HUVEC is caused by a direct virus effect or by a an indirect virus effect due to the induction of soluble compounds which are responsible for the enhancement in the adherence the following experiments were done: noninfected HUVEC monolayers were incubated with "supernatant medium" obtained from infected HUVEC monolayers. In addition also "supernatant medium" of CMV infected HEF monolayers was used. Firstly because it is known that CMV is able to infect HEF more efficiently than HUVEC it may be possible that CMV infection of HEF leads also to the induction of the adherence stimulating factor in this cell type. Secondly the CMV pool used was derived from these HEF monolayers, which exist of infectious virus plus the possible soluble compounds excreted by the infection. The results of these experiments pictured in fig. 4 showed that the increase in PMN adherence measured after $24 \mathrm{~h}$ p.i. was a direct virus effect and the "supernatant medium" derived 
from both infected cell monolayers did not induce an enhanced PMN adherence to noninfected HUVEC.

Contrariwise the PMNs adhered at random to the infected endothelial cell monolayers and not to the $10-15 \%$ of the cells, which represent the infected endothelial cells in the monolayer.

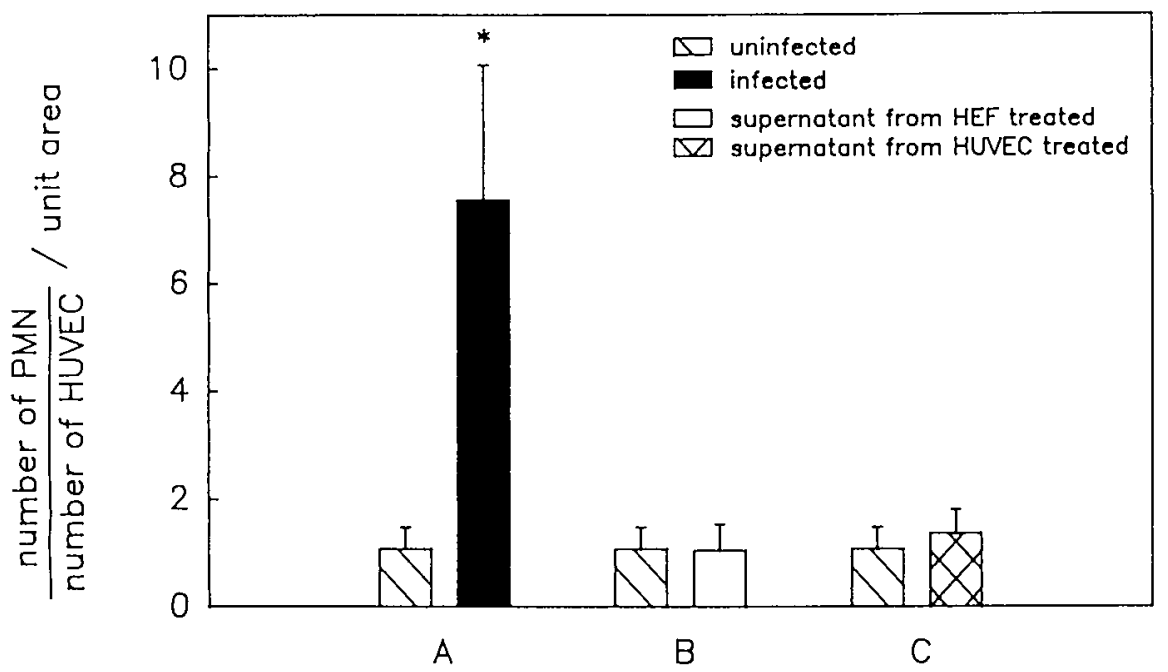

fig.4: Effect of supernatant from infected cells, on the adherence of PMNs to HUVEC. Adherence of PMNs to infected HUVEC (A), to supernatant (derived from infected HEF monolayers) treated HUVEC (B) and to supernatant (derived from infected HUVEC monolayers) treated HUVEC (C) after $24 \mathrm{~h} \mathrm{p.i.} \mathrm{is} \mathrm{expressed} \mathrm{as}$ the ratio of number of PMNs/number of HUVEC per unit area. Each bar expressed the mean of 40 areas. * $p$-value indicated above the bars are significant $(p \leq 0.001)$.

\subsubsection{Effect of tunicamycin on the virus induced enhancement of the PMN adherence}

To assess whether the enhanced adherence of PMNs to CMV infected HUVEC is the result of the appearence of glycoproteins on the surface of the HUVEC, we tested the effect of tunicamycin treatment on the adherence of PMNs. For this experiment HUVEC were infected and incubated in the presence of tunicamycin at 1 and $3 \mu \mathrm{g} / \mathrm{ml}$ and the adherence was measered $24 \mathrm{~h}$ p.i. Controls, consisted of either noninfected HUVEC monolayers, treated with tunicamycin, or infected HUVEC monolayers not exposed to tunicamycin. Fig. 5 shows that the treatment of infected monolayers with tunicamycin at a 
concentration of $3 \mu \mathrm{g} / \mathrm{ml}$ significantly reduced the CMV induced increase in adherence. Tunicamycin at a concentration of $1 \mu \mathrm{g} / \mathrm{ml}$ had less effect.

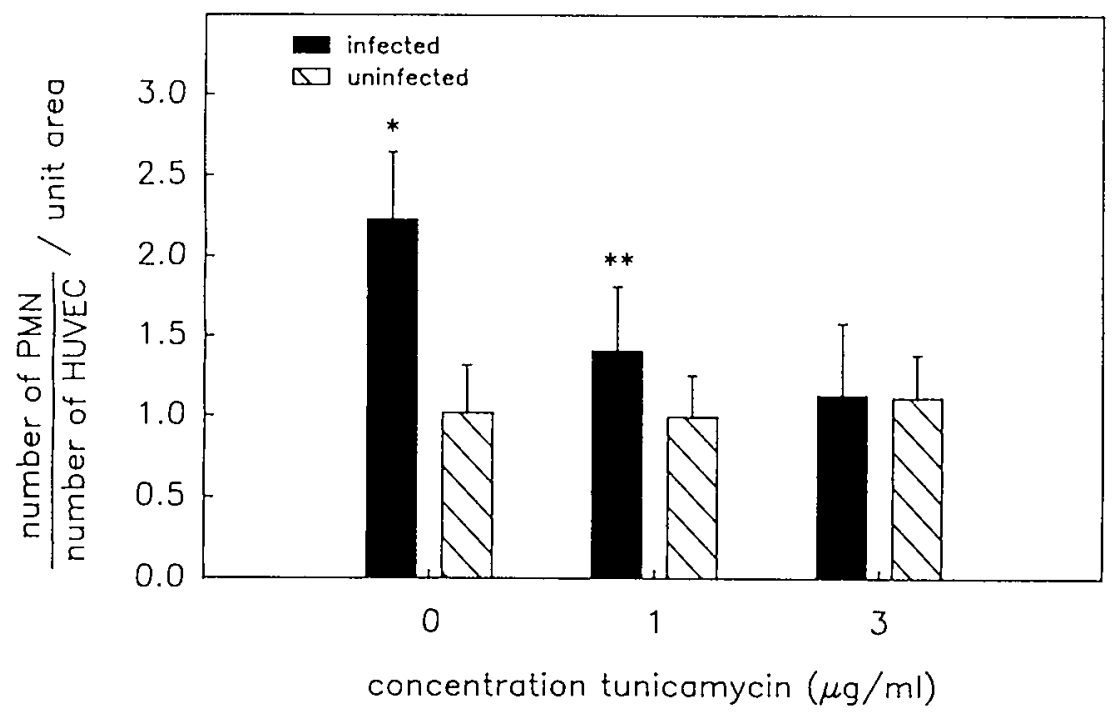

fig.5: Effect of tunicamycin on the virus induced enhancement of PMN adherence.

PMN adherence to infected HUVEC and noninfected HUVEC monolayers was measured after treatment with 1 and $3 \mu \mathrm{g} / \mathrm{ml}$ tunicamycin. Each bar expressed the mean of 40 areas. * p-value indicated above the bars are significant $(p \leq 0.001)$. ${ }^{* *} p$-value indicated above the bars are significant $(p \leq 0.05)$.

In contrast, tunicamycin treatment had no effect on the back ground adherence of PMNs to noninfected monolayers (fig.4). Furthermore, no morphologic changes or disruption were observed in infected or noninfected endothelial cell monolayers incubated with tunicamycin and the viability of the endothelial cell monolayer did not change.

\subsection{DISCUSSION}

Earlier work from our laboratory demonstrated that Herpes Simplex virus (HSV) infection of endothelial cells resulted in an infection rate of $100 \%$ and led to an increased adherence of monocytes to the infected cell monolayer. Glycoproteins expressed on the membranes of the infected endothelial cells were responsible for this effect (17). In the present paper we have examined the effect of CMV, another member of the herpesvirus group, on the adherence of PMNs to endothelial cell monolayers. 
As depicted in fig. 3 infection of HUVEC monolayers with CMV resulted in an increased adherence of PMNs, which occurred already at $24 \mathrm{~h} \mathrm{p.i.} \mathrm{(fig.2),} \mathrm{before}$ disruption of the infected cell monolayer. This result correlates with the findings of Zajac et al. (11) and MacGregor et al. (10) using HSV infected cell monolayers. Nevertheless it is remarkable that in our experimental assay in spite of the low percentage (10-15\%) of infected cells/HUVEC monolayer the effect on PMN adherence is obviously greater (500\% of control adherence) than found by them (200\% of the control adherence) on HSV infected endothial cell monolayers. In separate studies performed in our laboratory we have found that HSV infection of HUVEC monolayers leads to an increase of the PMN adherence of about $50 \%$ (to be published). These data suggest that CMV infection of HUVEC, in spite of the low infection rate, induces a larger effect on the PMN adherence than HSV infection.

The mechanism of the virus induced leukocyte adherence is largely unknown. A possible mechanism responsible for the enhanced PMN adherence could be the expression of viral and/or virus induced antigens on the surface of infected cells. The fact that enhanced adherence occurred already after $24 \mathrm{~h} \mathrm{p.i.} \mathrm{suggest} \mathrm{that} \mathrm{immediate} \mathrm{early} \mathrm{and/or}$ early viral functions, can be the initiators of this effect. This early virus induced phenomenon could be explained by the fact that CMV in contrast with most other viruses stimulates the host cell macromolecular synthesis even in the early phase of infection (before viral DNA synthesis) (18).

Another possibility could be the induction of an "adherence promoting factor" secreted by infected HUVEC monolayers. To determine this we have incubated the endothelial cell monolayers with virus and also with supernatant derived from the virus infected cells. Firstly, we can see, as depicted in fig.4, that PMN adherence to infected endothelial cell monolayers is a cell bound phenomenon and is not induced by the production of an "adherence stimulating factor" by the infected monolayers. These results are in accordance with the results obtained by MacGregor et al. (10) using HSV infected HUVEC. In these experiments the increase in the PMN adherence to HUVEC was not influenced by incubation of the cells with the supernate of the virus infected cells.

Secondly, we find that no clusters of PMNs were present on the infected endothelial cell monolayers. Starting from this date we suggest that the cell-bound factor present on infected HUVEC, stimulates other HUVEC to produce an antigen, which reacts with a ligand present on the PMNs. An other possibility is that the cell-bound factor present on the infected cells, stimulates the PMNs, during the $15 \mathrm{~min}$ incubation period, and these stimulated PMNs adhere at random to the endothelial cell monolayer.

The results obtained with PMNs as described in this paper differ from the results obtained with monocytes. In the latter we have found that the monocyte adherence to infected HUVEC monolayers was mediated by an "adherence promoting factor" secreted by these virus infected HUVEC monolayers (17).

In fig. 5 we can see that treatment of infected monolayers with the nucleoside antibiotic tunicamycin which prevents glycosylation abolishes the effect of CMV infection on the increase of PMN adherence showing that glycoproteins play a role in PMN adherence. Similar results were found in the leukocyte adherence experiments on virus infected endothelium described by others $(17,11)$. The results of all these experiments together show that tunicamycin treatment prevents the expression of glycoproteins on the surface of 
infected cells and that these glycoproteins are responsible for the increased adherence of PMNs and monocytes.

In conclusion comparing these PMN adherence findings here with those of monocytes described earlier, we postulate that there exist two different types of increased adherence of leukocytes to virus infected endothelium. The first one is mediated directly by viral and/or virus induced glycoproteins and plays a role in the adherence of PMNs. The second one is mediated by an "adherence promoting factor" produced by virus infected cells and plays a role in the adherence of monocytes. In both mechanisms glycoproteins are responsible for the the effect and treatment by tunicamycin prevents this effect.

Further experiments to study the mechanisms of virus induced adherence of leukocytes to endothelium and to analyse the antigens which are responsible for this phenomenon are necessary.

\subsection{ACKNOWLEDGEMENTS}

The authors wish to thank Mr. WHM Debie and Mr. W Mullers for their excellent technical assistance, Mrs. F Claus-Hahn and Mrs. L Kreusch for the preparation of the manuscript, and the Department of Obstetrics and Gynaecology of the University Hospital Maastricht, Maastricht, the Netherlands, for the supply of umbilical cords.

\subsection{REFERENCES}

1. Myerson D, Hackman RC, Nelson JA, Ward DC, McDougall JK. Widerspread presence of histologically occult cytomegalovirus. Hum Pathol 1984; 15: 430-439.

2. Bamji A, Salisbury R. Cytomegalovirus and vasculitis. Brit Med J 1978; 1: 623-624.

3. Mims CA, Gould J. Infection of salivary glands, kidneys, adrenals, ovaries and epithelial by murine cytomegalovirus. J Med Microbiol 1979; 12: 113-122.

4. Bruggeman CA, Debie WHM, Muller AD, Schutte B, Dam-Mieras MCE van. Cytomegalovirus alters the von Willebrand factor content in human endothelial cells. Thromb Haemostasis 1988; 59: 264-268.

5. Dam-Mieras MCE van, Bruggeman CA, Muller AD, Debie WHM, Zwaal RFA. Induction of endothelial cell procoagulant activity by cytomegalovirus infection. Thromb Res 1987; 47: 69-75.

6. Melnick JL, Petrie BL, Dreesman GR, Burek J, McCollum CM, Debakey ME. Cytomegalovinus antigen within human arterial smooth muscle cells. Lancet 1983; ii: 644-647.

7. Petrie BL, Melnick JL, Adam E, Burek J, McCollum CM, Debakey ME. Nucleic acid sequences of cytomegalovirus in cells cultured from human arterial tissue. J Infect Dis 1987; 155: 158-159.

8. Adam E, Probtsfield JL, Burek J, McCollum CH, Melnick JL, Petrie BL, Dailey KR, Debakey ME. High levels of cytomegalovirus antibody in patient requiring vascular surgery for atherosclerosis. Lancet 1987; 8: 291-293.

9. Taylor RG, Lewis JC. Endothelial cell proliferation and monocyte adhesion to atherosclerotic lesions of white carhcan pigeons. Am J Pathol 1986; 125: 152-160.

10. MacGregor RR, Friedman HM, Macarak EJ, Kefalides NA. Virus infection of endothelial cells increases granulocyte adherence. J Clin Invest 1980; 65: 1469-1477.

11. Zajac BA, O'Neill K, Friedman HM, MacGregor RR. Increased adherence of human granulocytes to herpes simplex virus type 1 infected endothelial cells. In Vitro Cellular \& Developmental Biology 1988; 24: 321-325. 
12. Maciag T, Cerundolo I, Istey S, Kelley PR, Foriand R. An endothelial cell growth factor from bovine hypothalamus: Identification and partial characterization. Proc Natl Acad Sci USA 1979; 76: 5674-5678.

13. Bruggeman CA, Meijer H, Dormans PHJ, Debie WHM, Grauls GELM, van Boven CPA. Isolation of a cytomegalovirus-like agent from wild rats. Arch Virol 1982; 73: 231-241.

14. Laurila P, Virtanen I, Wartiovaara J, Stenman S. Fluorescent antibodies and lectins strain intravascular structures in fixed cells treated with nonionic detergent. J Histochem Cytochem 1978; 26: $251-257$.

15. Verbrugh HA, Peters R, Peterson PK, Verhoef J. Phagocytosis and killing of staphylococci by human polymorphonuclear and mononuclear leukocytes. J Clin Pathol 1978; 31: 539-545.

16. Yam LT, Li CY, Crosby WH. Cytochemical identification of monocytes and granulocytes. Am J Pathol 1971; 5: 283-290.

17. Span AHM, Endert J, van Boven CPA, Bruggeman CA. Virus induced adherence of monocytes to endothelial cells. FEMS Microbiol Immunol 1989; 47: 237-244.

18. Yamanishi $K$, Rapp $F$. Induction of host DNA synthesis and DNA polymerase by DNA-negative temperature-sensitive mutants of human cytomegalovirus. Virology 1979; 94: 237-241. 


\section{CHAPTER VII}

THE EFFECT OF VIRUS INFECTION ON THE ADHERENCE OF LEUKOCYTES OR PLATELETS TO ENDOTHELIAL CELLS

*Span AHM, van Dam-Mieras MCE, Mullers W, Endert J, Muller AD, Bruggeman CA. European Journal of Clinical Investigation 21: 721, 1991 


\section{ABSTRACT}

It has been reported that atherosclerotic lesions contain genomic material belonging to members of the herpes family. This suggests that latent viral infection may be one of the atherogenic triggers. In this study we show that early infection of endothelial cell monolayers with Herpes Simplex virus type 1 (HSV-1) or Cytomegalovirus (CMV) results in an increased monocyte (MC) and polymorphonuclear leukocyte (PMN) adherence, but not in an increased platelet adhesion. Further, is demonstrated that MC and PMN respond differently to virus infected endothelial cell monolayers: PMN adhesion to CMV infected cells is approximately $430 \%$ of the control adherence, while the MC adherence is increased to $160 \%$. Also, a difference in virus acting is observed: the adherence of MC or PMN to HSV-1 infected endothelial cells is caused by a secreted adherence promoting factor, while the adherence of MC or PMN to CMV infected endothelial cells seems to be a cell-bound phenomenon. In addition, it was demonstrated that the augmentation of MC or PMN adherence to virus infected endothelial cells is sensitive to tunicamycin, suggesting that both virus infections induce the expression of glycoproteins on the endothelial cell membrane, which is responsible for the MC and PMN adhesion.

Thus, HSV-1 and CMV infection of endothelium results in an increased adherence of leukocytes which is suggested, irrespective of the precise nature of the mechanism of virus induced atherosclerosis, to be the earliest event associated with endothelium cell damage. 


\subsection{INTRODUCTION}

A continuous lining of the endothelial cells is important for the maintenance of cellular continuity and phenotype. Disruption of the continuous endothelial lining activates a number of pathophysiologic mechanisms whose purpose is to limit and repair vascular damage. Also, however, more subtle endothelial damage, which does not result in the disruption of endothelial lining induced by chemical, immunologic or viral agents, results in the continuous activation of inflammatory or coagulation systems.

In both situations, where the recruitment of leukocytes as well as the formation of platelet plugs at the site of vascular injury are induced, an attachment of circulating cells to the vascular endothelial cells is observed. It is probable that the different members of the integrin family, IgG superfamily and/or of the leuCam group of adhesive receptors (1$3)$ are involved in these interactions.

Viral infection of endothelium is a possible example of a more subtle injury. It has been shown that HSV-1 infects endothelial cells in vitro (4). In addition, in vivo observations showed that HSV-1 lesions often reveal granulocyte accumulation in and around the vessel walls together with trombin and fibrin deposits (5). Consistent with these in vivo observations, several authors (6-8) showed that granulocytes are attracted to HSV-1 infected endothelium in vitro. Corresponding results were obtained when endothelial cells were infected with CMV. Myerson et al. (9) and others (10) described the presence of CMV in endothelial cells in vivo. The presence of CMV in endothelium in humans was confirmed in a mouse model (11). According to these observations, we showed that CMV infection of endothelial cells in vitro resulted in the appearance of CMV antigens in the nuclei of about $10 \%$ of the endothelial cells, in the disappearance of the von Willebrand Factor, in an increased surface expression of endothelial cell procoagulant activity (12-14) and in an enhanced PMN adherence to the infected endothelial cell monolayer (15).

Injury to the vascular endothelium may be an initial event in the development of atherosclerosis. Previous studies have suggested that members of the herpes virus family are involved in the pathogenesis of atherosclerosis. Fabricant and colleagues $(16,17)$ observed that Marek's disease herpes virus (MDV) leads to occiusive atherosclerosis of the large arteries in hypercholesterolemic, but also in normocholesterolemic, chickens. The possible relationship between herpes viruses and human atherosclerosis was supported by the findings of Benditt et al. (18) who found HSV-RNA in the intima of atherosclerotic plaques, by Gyorkey et al. (19) who observed herpes virus particles in atherosclerotic lesions and by Melnick et al. (20) who detected CMV antigens in smooth muscle cells derived from the aorta of patients with atherosclerosis. Recently Adam et al. (21) has demonstrated high levels of CMV antibody in atherosclerotic patients. Those findings are confirmed by studies done in our laboratory (22).

Taken together, these observations suggest that HSV-1 and CMV can be important contributing factors in atherogenesis. Because of our interest in the early stages of atherosclerosis and the role of virus infection in this process, we investigated in this study the ability of HSV-1 or CMV to induce an increased adherence of PMN or MC to endothelial cells. Also the adherence of platelets to endothelial cells was examined. The results indicate that both viruses induce an enhanced PMN- and MC-adherence but no increase in platelet adhesion. The adherence mechanisms of PMN and MC appear to be different. 


\subsection{MATERIALS AND METHODS}

\subsubsection{Reagents}

All culture media were purchased from Gibco Biocult Co (Paisly, Scotland). Fetal calf serum and Newborn calf serum were obtained, respectively, from Boehringer (Mannheim, Germany) and Gibco Biocult Co. (Paisly, Scotland). Heparin was obtained from Serva (Heidelberg, Germany). Cell culture trays containing $96 \times 0.3 \mathrm{~cm}^{2}$ wells were obtained from Costar (Cambridge, MA, USA). Fibronectin was obtained from the central laboratory of the Dutch Red Cross Transfusion Service (CLB; Amsterdam, The Netherlands).

\subsubsection{Cell cultures}

Human endothelial cell cultures were prepared from umbilical cord veins as described (23) and were used in the adherence assay studies after five to eight doublings. Cells were grown in medium consisting of 50\% medium 199 (M199) and 50\% RPMI 1640 supplemented with heat-inactivated $20 \%$ fetal calf serum (FCS), heparin $(10 \mathrm{U} / \mathrm{ml}), 0.2 \%$ endothelial growth factor (egf) (24) and antibiotics.

Human embryonal fibroblasts (HEF) were cultured in Eagle's Minimum Essential Medium (MEM) supplemented with heat-inactivated (at $56^{\circ} \mathrm{C}$ for $30 \mathrm{~min}$ ) $10 \%$ newborn calf serum (iNCS) and antibiotics. Near-confluent HEF monolayers were used for the preparation of the CMV pool.

Vero cells were cultured in roller-bottles, in MEM supplemented with $10 \%$ iNCS to confluency, and used for the preparation of the HSV-1 pool.

\subsubsection{Virus}

Herpes Simplex virus type 1 (HSV-1), originally obtained from the American Type Culture Collection, was propagated in Vero cells as described earlier (23). After harvesting the supernatants the titres were evaluated by using a plaque assay as described for rat CMV (25). The virus pools were stored at $-70^{\circ} \mathrm{C}$ until used.

The Kerr strain of Cytomegalovirus (CMV), prepared by infecting HEF monolayers, was used. The infectivity of the CMV pool was also determined by the above mentioned plaque assay.

\subsubsection{Viral inoculation of the monolayer}

Endothelial cell monolayers were infected with CMV using the technique described previously (15). Briefly: 24 hrs before infection, the maintenance medium of nearconfluent endothelial cell monolayers was replaced by infection medium. Afterwards the monolayers were inoculated with CMV at a multiplicity of infection (MOI) of 30, unless indicated otherwise. After 60 minutes of virus incubation, at $37^{\circ} \mathrm{C}$ and a centrifugation 
speed of $1500 \mathrm{rpm}$, virus was removed and cells were re-fed with fresh the maintenance medium. Before being used in the leukocyte adherence experiments, these monolayers were incubated for another $24 \mathrm{hrs}$ in a $\mathrm{CO}_{2}$ incubator.

Subconfluent endothelial cell monolayers, infected with HSV-1 as described (23), were incubated with virus at a MOI of 10 . After an incubation period of $1 \mathrm{hr}$ the monolayers were washed and fresh maintenance medium was added. The monolayers were incubated for another $3 \mathrm{hrs}$ and used in the leukocyte adherence experiments.

To determine whether infected monolayers release a factor that induces the increased PMN or MC adherence, endothelial cell monolayers were incubated for $1 \mathrm{hr}$ with CMV or HSV-1. At, respectivily, 24 or 3 hrs post infection (p.i.), the supernatant media were collected and virus was removed by ultracentrifugation for 90 minutes at $110,000 \mathrm{~g}$. Noninfected endothelial cell monolayers were incubated with these supernates for $1 \mathrm{hr}$ and PMN or MC adherence was measured as described further.

Control monolayers were incubated with either medium harvested from non-infected monolayers of the same age as the infected ones (mock), or maintenance medium. No differences between mock-infected and untreated endothelial cells were found.

\subsubsection{Isolation of monocytes and polymorphonuclear leukocytes}

Human $\mathrm{MC}$ and PMN were isolated from blood obtained from healthy donors using the methods described previously $(23,15)$. Briefly, the buffycoat resuspended in acetate citrate dextrose solution was mixed with a $5 \%$ dextran T500 solution (Pharmacia, Uppsala, Sweden) in a ratio of $10 \mathrm{ml}$ suspension to $3 \mathrm{ml}$ dextran.

After a sedimentation time of $30 \mathrm{~min}$ at room temperature the PMN were subsequently harvested, dispended on cold Ficoll-Hypaque (Pharmacia, Uppsala, Sweden) and centrifuged for $35 \mathrm{~min}\left(600 \mathrm{~g}\right.$ at $\left.4^{\circ} \mathrm{C}\right)$. The pellet was washed twice and resuspended in RPMI 1640 supplemented with $1 \%$ FCS (RPMI 1640/1\% FCS).

The pellet, containing $\mathrm{MC}$ and lymphocytes, was fractionated by centrifugation ( 30 min, $700 \mathrm{~g}$ at $4^{\circ} \mathrm{C}$ ) on a discontinuous percoll gradient (Pharmacia, Uppsala, Sweden). The $\mathrm{MC}$, harvested from the $40 \% / 50 \%$ layer interface and from the $50 \% / 54 \%$ percoll interface, were washed twice and resuspended in RPMI 1640/1\% FCS.

The purity of the harvested MC and PMN was assessed by morphology as well by nonspecific esterase staining (26) for $\mathrm{MC}$ and by chloroacetate esterase staining (27) for PMN. Viability was determined by counting the percentage of cells that excluded trypan blue and was consistently found to be $\geq 95 \%$.

\subsubsection{Isolation of platelets}

Human platelets were isolated according to Bevers et al. (28). Washed platelets were resuspended in a calcium-free buffer ( $\mathrm{pH} 7.4$ ), containing $10 \mathrm{mM} \mathrm{Hepes,} 136 \mathrm{mM} \mathrm{NaCl}$, $2.7 \mathrm{mM} \mathrm{KCl}, 2 \mathrm{mM} \mathrm{Mg} \mathrm{Cl}$, $5 \mathrm{mM}$ glucose and $0.1 \%$ fatty acid-free human serum albumin. Platelet concentration was adjusted to $10^{8} / \mathrm{ml}$, using a Coulter counter. 


\subsubsection{Measurement of MC and PMN adherence}

The adherence of MC and PMN to endothelial cells was evaluated by a radiometric assay, as described previously (29). Briefly, after labelling the $\mathrm{PMN}$ or $\mathrm{MC}$ with ${ }^{51} \mathrm{Cr}$, the suspensions were incubated with infected, mock-infected, or with supernate-treated endothelial cell monolayers for $15 \mathrm{~min}$ at $37^{\circ} \mathrm{C}$. The monolayers with the attached cells were rinsed five times and lysed with trypsin/EDTA solution. After lysis the cell fractions were counted in a liquid scintillation counter to quantitate the leukocyte adherence. The number of cells attached was determined by calculating the counts per minute (cpm) remaining attached to the monolayer per total $\mathrm{cpm}$. The adherence to the control monolayers was considered to be $100 \%$. The other experimental values were expressed as a percentage of their control adherence by using the following formula: (adherence to treated endothelial cells: adherence to control endothelial cells) $\times 100 \%$.

\subsubsection{Measurement of platelet adherence}

Confluent endothelial cell monolayers $\left(2.10^{4}\right.$ cells/well in 96-well trays) were inoculated with CMV or HSV-1, as described above, or stimulated with thrombin $(0.4 \mathrm{U} /$ well for 30 min) and washed twice with RPMI 1640. Subsequently $0.2 \mathrm{ml}$ of RPMI 1640, of fibrinogen in RPMI $1640(0.5 \mathrm{mg} / \mathrm{ml})$, and of normal plasma in RPMI-1640 was added, respectively, and the cells were incubated for $30 \mathrm{~min}$. Finally, the supernatant was removed, the cells were washed twice with RPMI 1640 and $0.2 \mathrm{ml}$ platelet suspension in RPMI 1640 ( $10^{8}$ platelets/ $\left.\mathrm{ml}\right)$ or $0.2 \mathrm{ml}$ RPMI 1640 was added. After $30 \mathrm{~min}$ incubation the supernatant was removed, the cells were washed again twice with RPMI 1640 and stained with Rose Bengal (30). After extraction of the dye, extinction was measured at 550 $\mathrm{nm}$ in an ELISA-plate reader. The platelet-adherence was also expressed as a percentage of control adherence as described above for leukocytes.

\subsubsection{Treatment of endothelial cells with tunicamycin}

Endothelial cell monolayers were inoculated with virus as described above. After inoculation, tunicamycin (Sigma, St. Louis, MO, USA) at a concentration of $3 \mu \mathrm{g} / \mathrm{ml}$ was added to the infection medium. The monolayers infected with CMV or HSV-1 were further incubated for 23 or $3 \mathrm{hrs}$, respectively. At 24 or $4 \mathrm{hrs}$ p.i. the adherence experiments were done as described above. Mock-infected monolayers were used as controls and also virus infected monolayers without tunicamycin were included.

\subsubsection{Statistics}

To test the effect of virus infection on the MC or PMN adherence the Wilcoxon test was used. If the $p$-value was $\leq 0.05$ the results were statistically different. 


\subsection{RESULTS}

\subsubsection{Effect of HSV-1 or CMV infection on the MC and PMN adherence}

HSV-1 or CMV infected endothelial cell monolayers were used to determine whether virus infection causes an effect on the adherence of MC or PMN. The number of adherent cells to virus infected endothelial cells is compared with the number of cells adherent to mockinfected endothelial cells. Fig. 1 demonstrates that both CMV and HSV-1 infections result in an increased $\mathrm{MC}$ and PMN adherence. The MC adherence to HSV-1 infected endothelial cells increases to $190 \%$ of the control adherence, and the PMN adherence increases to almost the same amount (180\% of the control adherence). In contrast, a $430 \%$ increase of PMN adherence is seen to CMV infected endothelial cells, while the MC adherence only shows a $160 \%$ increase.

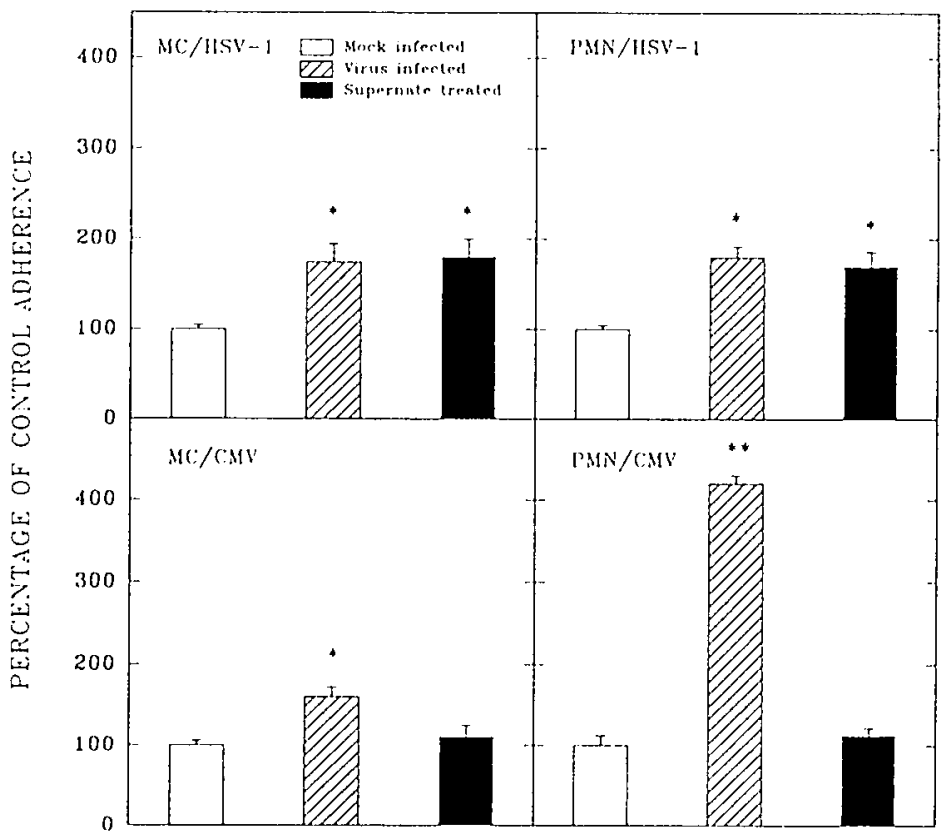

fig. 1: Adherence of radiolabeled MC and PMN to: mock- infected; HSV-1 or CMV infected; or supernatant(derived from HSV-1 or CMV infected monolayers) treated endothelial cell monolayers. MC and PMN were incubated with the monolayers for $15 \mathrm{~min}$ and adherence is assayed as described in the "Methods" section. The results are expressed as mean (bars) \pm SEM (brackets) of 8 replicates. The increases in MC and PMN adherence to HSV-1 infected-, CMV infected- or supernatant medium, derived from HSV-1 infected monolayers, treated endothelial cells are significant (*: P $\leq 0.001, * *: \mathrm{P} \leq 0.0001$; Student's-t-test). However, $M C$ and PMN adherences to supernatant medium, derived from CMV infected monolayers, treated endothelial cells are not increased $(\mathrm{P}>0.05)$. 
7.3.2 The effect of supernatant of virus infected cells on the adherence of $\mathrm{MC}$ and PMN to endothelial cells

To investigate whether the increased $\mathrm{MC}$ and PMN adherence to virus infected endothelial cells is a cell bound effect or is due to the induction of soluble compounds which induce a response in neighbouring cells, the following experiments were done. Non-infected endothelial cell monolayers were incubated with supernatant derived from infected monolayers. The data pictured in fig. 1 show that the supernate derived from HSV-1 infected monolayers increases MC and PMN adherence. On the other hand, supernatant medium derived from CMV infected endothelial cells does not increase the MC and PMN adherence. An adherence of 105 and $107 \%$ was measured, respectively.

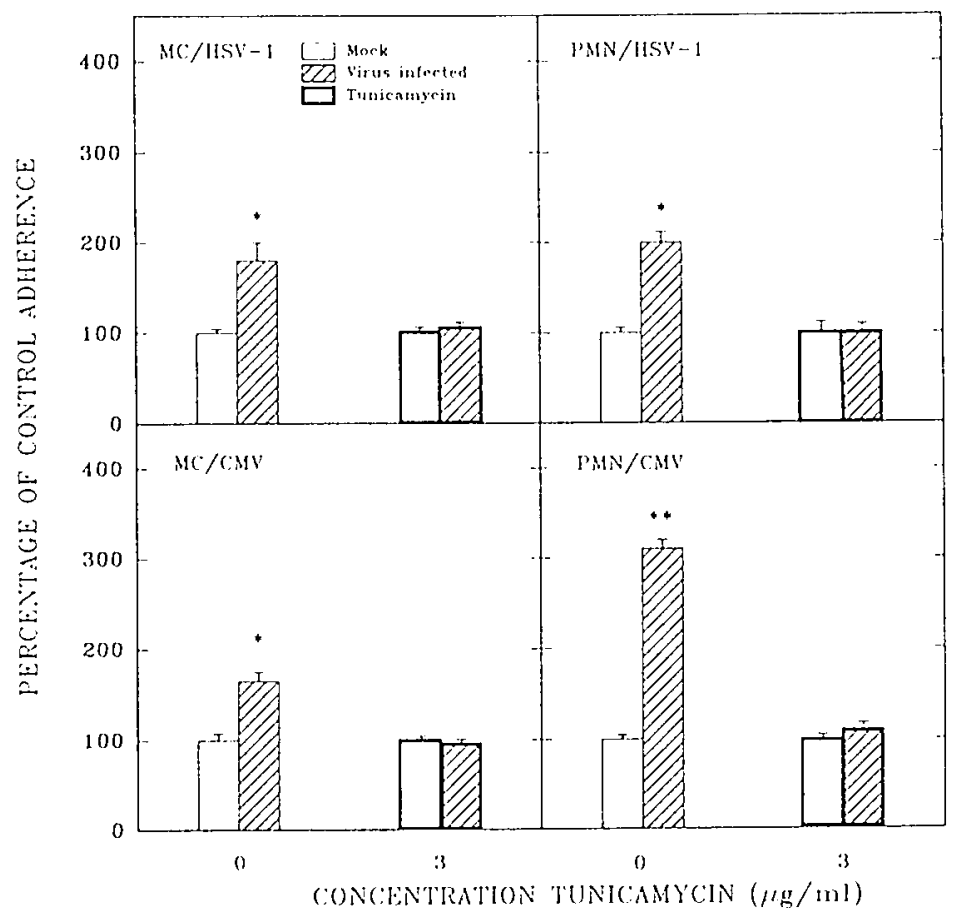

fig. 2: Effect of tunicamycin on MC and PMN adherence to mock infected and virus infected endothelial cell monolayers. MC and PMN adherence to the monolayers was measured after treatment with $3 \mu \mathrm{g} / \mathrm{ml}$ tunicamycin (represented by heavy lined bars). Each bar expresses the mean of 8 replicates. *: P-value indicated above the bars was significant $(P<0.05)$. **: P-value indicated above the bar was significant ( $\mathrm{P} \leq 0.001)$. 


\subsubsection{The effect of tunicamycin on the virus induced PMN or MC adherence}

To determine if the enhanced PMN and MC adherence to virus infected endothelial cells is caused by the expression of glycoproteins on the surface of endothelial cells, we tested the effect of tunicamycin treatment on the adherence of PMN and MC to infected monolayers. The endothelial cells were treated with tunicamycin $(3 \mu \mathrm{g} / \mathrm{ml})$ after virus inoculation, until used in the adherence assay.

As controls either mock-infected endothelial cell monolayers treated with tunicamycin or untreated virus infected endothelial cell monolayers were used.

As depicted in fig. 2 tunicamycin concentration of $3 \mu \mathrm{g} / \mathrm{ml}$ is sufficient to inhibit both, PMN and MC, adherences induced by HSV-1 infection. Corresponding results were obtained when monolayers were infected with CMV (fig.2). Furthermore, it is evident that the background adherence of PMN or MC, i.e. to mock-infected endothelial cells, was not affected. No morphologic changes or disruption of the endothelial cell monolayers were observed nor was the viability of the endothelial cell monolayers changed after tunicamycin treatment (data not shown).

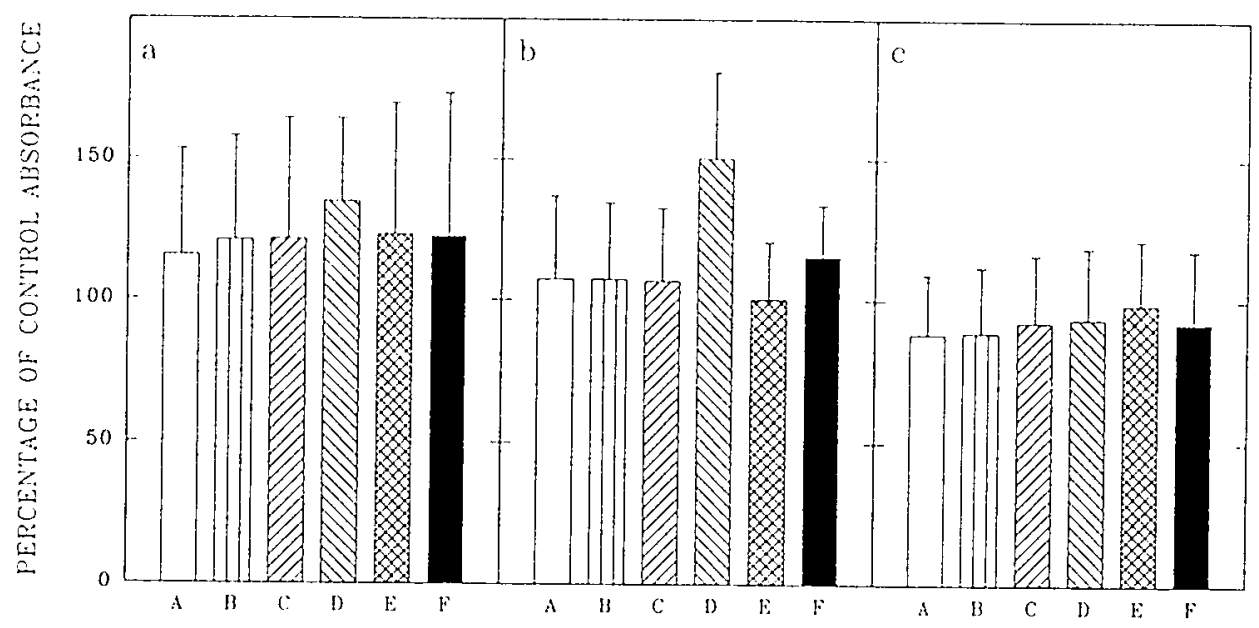

fig.3: Platelet adhesion to endothelial cells as determined by Rose Bengal staining. In (a) adhesion is carried out in the absence of fibrinogen and plasma; in (b) fibrinogen is added to the assay system and in (c) plasma is added. The increase in Rose Bengal staining after platelet adhesion is compared to that obtained in the same preparation without added platelets. A: non-infected endothelial cells. B: HSV-1 infected endothelial cells. C: CMV infected endothelial cells. D: thrombin stimulated endothelial cells. E: supernatant medium, derived from HSV-1 infected monolayers, treated endothelial cells. F: supernatant medium, derived from CMV infected monolayers, treated endothelial cells. Bars represent means \pm SEM of 4 experiments with 4 replicates per experiment. The magnitude of the standard deviation is mainly determined by difference between the endothelial cell monolayers obtained from individual umbilical cords. Within one experiment (which means working with a cell population obtained from one umbilical cord) the standard deviation is much smaller. P-values were $>0.05$. 


\subsubsection{Effect of HSV-1 and CMV infection on the adherence of platelets}

An increase in platelet adhesion might be direct, involving an increased receptor expression or activation of adhesive receptors, or secondary to thrombin formation during a procoagulant response (12-14). Therefore, the platelet adhesion to virus infected endothelial cells was compared to non-infected control cells and to thrombin-stimulated cells. As cytokine secretion might play a role in the induction of platelet adhesion after viral infection, the effect of culture supernatants derived from virus infected endothelial cells on the adhesion of platelets to non-infected endothelial cells was investigated. The results are shown in fig.3a and indicate that under these experimental conditions, thrombin stimulation results in a slight increase in platelet adhesion while virus infection has no effect.

The presence of fibrinogen is a prerequisite for platelet aggregation, therefore the effect of the presence of fibrinogen in the assay system on the platelet adhesion to endothelial cell monolayers was tested. The experiments are summarized in fig. $3 \mathrm{~b}$. The results show that only thrombin stimulation gives a slight increase in platelet adhesion.

As viral stimulation of endothelial cell monolayers results in the formation of procoagulant complexes on the endothelial cell surface $(12,31)$ upon interaction of the cell with plasma components, the effect of plasma in the adhesion assay system was studied (fig.3c). These results show that the presence of plasma "protects" the cells from platelet adhesion.

\subsection{DISCUSSION}

Earlier work from our laboratory has demonstrated that infection of endothelial cells with different viruses leads to an increased adhesion of leukocytes to the infected monolayer $(15,23)$.

In the present paper we focus on HSV-1 and CMV infections, in order to define the characteristics of MC, PMN and platelet adherence, and to determine the mechanisms responsible for these adherences. From previous work it is known that HSV-1 infection of endothelial cells eventually results in an infection rate of $100 \%$ if high multiplicity of infections are used. In our experimental conditions HSV-1 antigens are already detected after $3 \mathrm{hrs}$ of infection. At that time more than $20 \%$ of the cells show a bright staining in the nucleus (when immunofluorescence technique was used). Cytopathological changes, limited to differences in the size and shape of endothelial cells, can be visualized by light microscopy between 4 and $8 \mathrm{hrs}$. At that time, all cells remain alive and no cell loss is observed. Between 24 and $48 \mathrm{hrs}$, however, the infected monolayers begin to detach from their surfaces.

Although a high multiplicity of infection of 10 (or more) is used, CMV infection of endothelial cell monolayers only results in an infection of $10 \%-15 \%$ of the cells (15). In these cell monolayers no cytopathologic effects (cpe) are observed. Between day 5 and 8 p.i. an increase in the amount of infectious virus is detected in the cells and in the supernatant medium.

In this paper we show that infection of endothelial cells with HSV-1 results in an increased adherence of MC (190\%) and PMN (180\%) which already occurs at 3 hrs p.i. 
Zajac et al. (32) found a similar adherence percentage, only starting after 6 hrs of infection, and Visser et al. (6) measured an increased PMN adherence after 18 hrs of HSV-1 infection, almost in the same range as we found. This difference in time is probably due to the fact that the endothelial cells used in our model differ from theirs. Visser et al. uses confluent monolayers which show minimal cytopathic changes by light microscopy not before $18 \mathrm{hrs}$ of infection, while in our assay, using subconfluent monolayers, cpe already starts between 3 and 8 hrs p.i.

When endothelial cells are infected with CMV, an increased adherence is measured at 24 hrs p.i. At that time the MC adherence is increased to $160 \%$, while the PMN adherence is increased to $430 \%$. This difference in adherence is probably explained by the difference in function of both cell types. PMN are active in an acute phase, while MC are acting in a later stage of the immune response. Comparing the infection rate of HSV-1 and CMV with the PMN adherence to virus infected monolayers it is remarkable that, in spite of the low percentage of CMV infected cells, the effect on PMN adherence is remarkably higher. These data suggest that CMV infection induces a larger effect on the PMN adherence than HSV-1 infection, which also suggests that both viruses act differently.

The mechanisms by which PMN and MC increase their adherence to virus infected endothelial cell monolayers is not entirely clear. A possible mechanism involves virus specific antibodies present in human serum, directed against viral glycoproteins expressed on the surface of infected endothelial cells as shown by others $(32,7)$. But, as in our adhesion model no human serum is added, the explanation must be different. The fact that the enhanced adherence occurs early after virus infection suggests that immediate early and/or early viral functions can be the initiators of this effect. It is known that CMV, in contrast to other viruses, stimulates the host cell macromolecule synthesis even in the early phase of infection (before viral DNA synthesis) (33). Incubation experiments with cycloheximide in the culture medium, done in our laboratory, showed a decrease in adherence to virus infected endothelial monolayers (data not shown). These results support the above-mentioned hypothesis. In addition, the generation of thrombin through virus infection (34) can by responsible for the leukocyte adherence stimulation (35).

Another possibility can be the induction of an adherence promoting factor, secreted by infected endothelial cells. To test this hypothesis we incubated endothelial cell monolayers with supernate derived from virus infected cells. As depicted in fig. 1, the adherences of MC and PMN to HSV-1 infected endothelial cells are caused by the secretion of an adherence promoting factor. However, the adherence of MC and PMN to CMV infected endothelial cells seems to be a cell-bound phenomenon. The HSV-I result is in contrast with the findings of MacGregor et al. (7) who found that the HSV-1 induced PMN adherence to bovine endothelial cells was a cell-bound phenomenon; it was not induced indirectly by the release of a soluble substance that acts directly on endothelial cells. Possible soluble candidates that play a role in HSV-1 mediated MC or PMN adherence are interferon, tumor necrosis factor and IL-1 (36). These mediators are individually or collectively produced and released by mononuclear leukocytes and other cells, like endothelial cells, in response to bacterial products and viruses (37). The functional responses elicited by these cytokines in endothelial cells are increased expression of ICAM-1, ICAM-2 and of ELAM 1 (38), which in turn are involved in the interaction between endothelial cells and leukocytes. 
Further, it is shown that tunicamycin, which hinder glycosylation, abolishes the HSV-1 and CMV induced adherence of MC and PMN. This indicates that glycoproteins induced by virus infection play a role in PMN and $\mathrm{MC}$ adherence. This result is in accordance with the findings of Norrild and Pederson (39) who observed that tunicamycin prevents the expression of viral glycoproteins on the surface of infected cells. Pizer et al. (40) showed a similar tunicamycin effect and speculated that tunicamycin interferes with the synthesis of HSV-1 specific glycoproteins. Zajac et al. (32) have demonstrated that viral glycoproteins were involved in the granulocyte adherence to HSV-1 infected endothelial cells. Also, next to viral glycoproteins, virus induced glycoproteins can be responsible for the enhanced adherence, like glycoprotein E, which functions as an Fc receptor (41) and glycoprotein C, which is a C3b-receptor (8).

As shown above, the inoculation of endothelial cells with HSV-1 and CMV results in an increased adherence of leukocytes. As platelets are in some respect inflammatory cells $(42,43)$ the effect of HSV-1 and CMV infection on the endothelial cell-platelet interaction is also studied. Further it is investigated whether or not a potential endothelial cell-platelet interaction is mediated directly by adhesive receptor molecules, or occurs secondary to the formation of thrombin on the cellular surface. As in earlier studies, we have shown that CMV infection induces a procoagulant response in endothelial cells (12).

For the detection of platelet-endothelial cell interaction the method of Gamble \& Vadas (30) is used. This vital cell staining method has the advantage that prelabelling of platelets with the inherent risk of platelet activation, is not necessary. However, the quantification of platelet-endothelial cell adherence is less easy than with ${ }^{51} \mathrm{Cr}$ labelled platelets. When the staining of non-infected, virus infected and thrombin stimulated endothelial cells in the absence of platelets, fibrinogen and plasma are compared, no change in cellular staining by virus infection or thrombin stimulation is found. When fibrinogen or plasma are added to the assay system some increase in staining intensity of thrombin stimulated endothelial cells was observed. Non-infected and virus infected endothelial cells only give an increased staining in the presence of plasma (data not shown). We cannot give a straight forward explanation for this observation, but it may be caused by the adsorption of plasma components to the endothelial cell surface. So one must realize that an increase in staining can already occure in absence of platelets. This result emphasizes the necessity of a very careful experimental standardization; for each platelet adhesion assay the correct control preparation, containing all components without platelets, should be used. The results obtained in the presence of platelets (fig. $3 \mathrm{a}-\mathrm{c}$ ) show that only in the case of thrombin stimulation a slight increase in platelet adhesion to the endothelial cell monolayer can be found; the presence of fibrinogen in the adhesion system seems to reinforce this effect to a very limited extent.

Infection of the endothelial cells with CMV or HSV-1 does not enhance the platelet adhesion. A similar result in platelet adhesion is described by Visser et al. (34) after HSV1 infection. Further, it is demonstrated that plasma apparently protects the endothelial cell monolayer from platelet adhesion. This phenomenon can be understood easily when we realise that the interaction of (stimulated) endothelial cells with plasma components could indeed result in the formation of procoagulant complexes on the cellular surface. However, at the same time plasma is a very rich source of coagulation factor inhibitors. This interaction of endothelial cells with plasma components and the effect of different 
endothelial cell stimuli on this interaction is presently under investigation in our laboratory.

In conclusion this paper shows that HSV-1 or CMV infection of endothelial cells results in the enhanced adherence of MC and PMN, but not of platelets. It is postulated that HSV-1 infection of endothelial cells results in the secretion of soluble compounds, which in turn mediate the enhanced MC or PMN adherence. On the contrary, CMV infection does not lead to the secretion of soluble factors, but the MC and PMN adherence are cell-bound phenomena. In both infections glycoproteins are responsible for the virus effect, and treatment with tunicamycin abolish this effect.

\subsection{ACKNOWLEDGEMENTS}

The autors wish to thank Mrs F. Claus-Hahn for the preparation of the manuscript, the Department of Obstetrics and Gynaecology and the Bloodbank of the University Hospital Maastricht, Maastricht, The Netherlands, respectively for the supply of umbilical cords and of the buffycoats.

This work was supported in part by the Dutch Heart Association Grant 88-235.

\subsection{REFERENCES}

1. Patarroyo M, Makgoba MW. Leukocyte adhesion to cells. Molecular basis, physiological relevance and abnormalities. Scand J Imnunol 1989; 30: 129-64 (review).

2. Phillips DR, Chara IF, Parise LV, Fitzgerald LA. The platelet membrane glycoprotein IIb-IIla complex. Blood 1988; 71: 831-43.

3. Ginsberg MH, Loftus JC, Plow EF. Cytoadhesins, integrins and platelets. Thromb Haemis 1988; 59: 16.

4. Friedman HM, Macarak EJ, MacGregor RR, Wolfe J, Kefalides NA. Vins infection of endothelial cells. J Infect Dis 1981; 143: 266-73.

5. McSorley J, Shapiro L, Brownstein MH, Hsu KC. Herpes simplex and Varicella zoster: Comparative histopathology of 77 cases. Intern J Dermatol 1974; 13: 69-75.

6. Visser MR, Jacob HS, Goodman JL, McCarthy JB, Furcht LT, Vercellotti GM. Granulocyte-mediated injury to Herpes simplex virus-infected human endothelium. Lab Invest 1989; 60: 296-304.

7. MacGregor RR, Friedman HM, Macarak EJ, Kefalides NA. Virus infection of endothelial cells increases granulocyte adherence. J Clin Invest 1980; 65: 1469-77.

8. Friedman HM, Cohen GH, Eisenberg RJ, Seidel CA, Cines DB. Glycoprotein C of Herpes simplex virus 1 acts as a receptor for the $\mathrm{C} 3 \mathrm{~b}$ complement component on infected cells. Nature (London) 1984; 309: 633-5.

9. Myerson D, Hackman RC, Nelson JA, Ward DC, McDougall JK. Widerspread presence of histologically occult cytomegalovirus. Hum Pathol 1984; 15: 430-9.

10. Bamji A, Salisbury R. Cytomegalovirus and vasculitis. Brit Med J 1978; 1: 623-4.

11. Mims CA, Gould J. Infection of salivary gland, kidneys, adrenals, ovaries, and epithelial by murine cytomegalovirus. J Med Microbiol 1979; 12: 113-22.

12. Dam-Mieras, MCE van, Bruggeman CA, Muller AD, Debie WHM, Zwaal RFA. Induction of endothelial cell procoagulant activity by cytomegalovirus infection. Thromb Res 1987; 47: 69-75.

13. Bruggeman CA, Debie WHM, Muller AD, Schutte B, Dam-Mieras MCE van. Cytomegalovirus alters the von Wille-brand factor content in human endothelial cells. Thromb Haemostasis 1988; 59: $264-8$. 
14. Kaplan JE, Moon DG, Weston LK, Minnear FL, Del Vecchio PJ, Shepard JM, Fenton II JW. Platelets adhere to thrombine-treated endothelial cells in vitro. Am J Physiol 1989; 257: H423-33.

15. Span AHM, van Boven CPA, Bruggeman CA. The effect of cytomegalovirus infection on the adherence of polymorphonuclear leukocytes to endothelial cells. Eur J Clin Invest 1989; 19: 542-8.

16. Fabricant CG, Fabricant J, Litrenta MM, Minick CR. Virus induced atherosclerosis. J Exp Med 1978; 148: $335-40$.

17. Hajjar DP, Fabricant CG, Minick CR, Fabricant J. Virus induced atherosclerosis. Herpes virus infection alters aortic cholesterol metabolism and accumulation. Am J Pathol 1986; 122: 62-70.

18. Benditt EP, Barrett T, McDougall JK. Viruses in the etiology of atherosclerosis. Proc Natl Acad Sci USA $1983 ; 80: 6386-89$.

19. Gyorkey F, Melnick L, Guinn GA, Gyorkey P, Debakey ME. Herpes viridae in the endothelial and smooth muscle cells of the proximal aorta in artherosclerotic patients. Exp Mol Pathol 1984; 40: $328-39$.

20. Melnick JL, Petrie BL, Dreesman GR, Burek J, McCollum GH, Debakey ME. Cytomegalovirus antigen within human arterial smooth muscle cells. Lancet 1983; 11: 644-7.

21. Adam E, Probtsfield JL, Burck J, McCollum CH, Melnick JL, Petrie BL, Bailey KR, Debakey ME. High levels of cytomegalovirus antibody in patients requiring vascular surgery of atherosclerosis. Lancet 1987; 8: 291-3.

22. Hendrix MGR, Salimans MMM, van Boven CPA, Bruggeman CA. High prevalence of latently present cytomegalovirus in arterial walls of patients suffering from grade III atherosclerosis. Am J Pathol 1990; 136: $23-8$.

23. Span AHM, Endert J, van Boven CPA, Bruggeman CA. Virus induced adherence of monocytes to endothelial cells. FEMS Microbiol Immunol 1989; 47: 237-41.

24. Maciag T, Gerundolo I, Ilsley S, Kelley PR, Foriand R. An endothelial cell growth factor from bovine hypothalamus: Identification and partial characterization. Proc Natl Acad Sci USA 1979; 76: 5674-8.

25. Bruggeman CA, Debie WHM, Grauls G, van Boven CPA. Cytomegalovirus infection of rat endothelial cells in vitro. Arch Virol 1986; 87: 265-72.

26. Lawrence C, Grossman R. Simple butyrate esterase stain for monocytes. Stain Technol 1980; 54: $321-3$.

27. Yam LT, Li CY, Crosby WH. Cytochemical identification of monocytes and granulocytes. Am J Pathol $1971 ; 5: 283-90$.

28. Bevers EM, Comfurius P, Zwaal RFA. The nature of the binding for prothrombinase at the platelet surface as revealed by lipotylic enzymes. Eur J Biochem 1982; 122: 81-5.

29. Span AHM, Mullers W, Miltenburg AMM, Bruggeman CA. Cytomegalovirus induced PMN adherence in relation to an ELAM-1 antigen present on infected endothelial cell monolayers. Immunol 1991, 72: 355-60.

30. Gamble JR, Vadas MA. A new assay for the measurement of the attachment of neutrophils and other cell types to endothelial cells. J Immunol Methods 1988; 109: 175-84.

31. Dam-Mieras MCE van, Muller AD, van Hinsbergh V, Bruggeman $C A$. The procoagulant response of cytomegalovirus infected endothelial cells. Submitted for publication.

32. Zajac BA, O'Neill K, Friedman HM, MacGregor RR. Increased adherence of human granulocytes to Herpes simplex virus type I infected endothelial cells. In Vitro Cellular \& Developmental Biology 1988; 24: $321-5$.

33. Yamanishi K, Rapp F. Induction of host DNA synthesis and DNA polymerase by DNA-negative temperature-sensitive mutants of human cytomegalovins. Virology 1979; 94: 237-41.

34. Visser MR, Tracy PB, Vercellotti GM, Goodman JL, White JG, Jacob HS. Enhanced thrombin generation and platelet binding on Herpes simplex virus-infected endothelium. Proc Natl Acad Sci USA $1988 ; 85: 8227-30$.

35. Etingin OR, Silverstein RL, Friedman HM, Hajjar DP. Viral activation of the coagulation cascade: Molecular interactions at the surface of infected endothelial cells. Cell 1990; 61:657-62.

36. Friedman RM, Vogel SN. Interferons with special emphasis on the immune system. In: Dixon FJ, Kunkel HG, eds. Adv Immunol 34. New York: Academic Press 1983: 97-140.

37. Steinbeck MJ, Roth JA. Neutrophil activation by recombinant cytokines. Rev Infect Dis 1989; 11 : 54968. 
38. Mantovani A, Dejana E. Cytokines as communication signals between leukocytes and endothelial cells (Review). Immunol Today 1989; 10: 370-5.

39. Norrild B, Pederson B. Effect of tunicamycin on the synthesis of Herpes simplex vinus type 1 glycoproteins and their expression on the cell surface. J Virol 1982; 43: 395-402.

40. Pizer LI, Cohen GH, Eisenberg RJ. Effect of tunicamycin on Herpes simplex virus glycoproteins and infectious virus production. J Virol 1980; 34: 142-53.

41. Para MF, Baucke RB, Spear PG. Glycoprotein gE of Herpes simplex virus type 1: effects of anti-gE on virion infectivity and on virus induced Fc-binding receptors. J Virol 1982; 41: 129-36.

42. Oxholm $P$, Winther $K$. Thrombocyte involvement in immune inflammatory reactions. Allergy 1986; 41 : $1-10$.

43. Joseph M. Platelets in allergy-assay interpretation. Clin Rev Allergy 1988; 6: 191-210. 

CHAPTER VIII

CYTOMEGALOVIRUS INDUCED PMN ADHERENCE IN RELATION TO AN ELAM-1 ANTIGEN PRESENT ON INFECTED

ENDOTHELIAL CELL MONOLAYERS

*Span AHM, Mullers W, Miltenburg AMM, Bruggeman CA Immunology 72: 355, 1991 


\begin{abstract}
In human umbilical vein endothelial cells infected with Cytomegalovirus (CMV), an activation antigen recognized by monoclonal antibody (MoAb) ENA1 appeared. MoAb ENAl reacts with an inducible endothelial surface antigen which has characteristics similar to those of ELAM-1. Incubation with anti-IL-1 partly inhibited this appearence and, parallel to this, the virus induced polymorphonuclear cell (PMN) adhesion was decreased. In addition, the adhesion of PMN to virus-infected endothelial cells could be reduced by $\mathrm{F}(\mathrm{ab})_{2}$-fragments of MoAb ENAl to almost control level.

The results obtained after incubation of PMN with MoAb IB4 (against CD18) suggest that the adhesion of PMN to uninfected endothelial cells is CD18 glycoprotein dependent, and virus infection up-regulates this glycoprotein-dependent mechanism.

These results indicate that the virus induced PMN adhesion is regulated by the following mechanism: virus infection of endothelial cells induces IL-1 production, and the autocrine IL-1 causes the expression of ELAM-1 on the surface of endothelial cells. In turn this activation antigen ELAM-1 binds with its putative ligand present on the PMN membrane. The virus-induced PMN adhesion occurs also through a CD18 glycoprotein-dependent mechanism.
\end{abstract}




\subsection{INTRODUCTION}

Endothelial damage is considered to be an important early event in the pathogenesis of atherosclerosis (1). It has been proposed that endothelial damage by herpes viruses may play a role in the etiology of atherosclerosis. The association of herpes virus infection and atherosclerosis is based on several observations. Marek's disease, caused by an avian herpes virus, induces atherosclerotic lesions, which closely resemble human atherosclerotic lesions (2). In man, herpes virus particles have been observed by electron microscope in the proximal aorta of atherosclerotic patients (3), and cytomegalovirus (CMV) antigens (4) and CMV nucleic acids (5) have been detected within atherosclerotic plaques. The mechanisms by which herpes virus infection does cause endothelial damage are not clear, and several possibilities have been put forward. Infection and reactivation of latent infection might lead to actual endothelial lysis (6). Or, as hypothesized by Visser, inflammatory cells are attracted to and marginate on virus-infected endothelium and initiate the development of atherosclerosis (7). Regarding this last mechanism, others have shown that herpes virus infection enhances granulocyte adherence to endothelial cells (8-10). However, the cellular mechanisms by which virus induces this effect are still not defined. It is known that virus infection induces changes in the endothelial plasma membrane, like the appearance of $\mathrm{Fc}$ and $\mathrm{C} 3 \mathrm{~b}$ endothelial receptors $(11,12)$. Further virus infection results in an abrogation of prostacyclin synthesis and in an increased thrombin generation (7), through which endothelial cell properties shift from anticoagulant to procoagulant. Van Dam-Mieras (13) observed that CMV infection of endothelial cells resulted in an increased procoagulant activity. Another possibility, by which virus induces an enhanced granulocyte adhesion, is the secretion of soluble factors by endothelium after virus infection (9), such as prostaglandins (14), platelet-activating factor (PAF) (15) and interleukin-1 (IL-1) (16, 17). From this last mediator it is known that it stimulates the endothelial plasma membrane, resulting in an avid adhesion of neutrophils, monocytes (18) and lymphocytes (19). By others it is demonstrated that ICAM-1, ICAM-2 (20), GMP-140 (21) and ELAM$1(22,23)$ are involved in this leucocyte adhesion. Recently, another cytokine-inducible endothelial cell receptor for neutrophils was described (24). This antigen, recognized by MoAb ENA1, is rapidly redistributed to the plasma membrane during activation and is structurally related to ELAM-1 (25).

This study concerns the hypothesis that virus infection leads to activation of endothelial cells, which results in interleukin-1 (Il-1) secretion. This Il-1 stimulates the endothelial cells causing a changed antigen membrane expression and an increased leucocyte adhesion. The role of the activation antigen ELAM-1 is investigated within this process. For this purpose, endothelial cell monolayers were infected with CMV. At different hours post infection (p.i.), viral and surface antigen expressions were determined and polymorphonuclear $(\mathrm{PMN})$ cell adhesion was measured. 


\subsection{MATERIALS AND METHODS}

\subsubsection{Reagents}

The culture media were purchased from Gibco Biocult Co (Paisley, Renfrewshire, Scotland). Foetal calf serum and newborn calf serum were obtained from Boehringer (Mannheim, Germany) and Gibco Biocult Co., respectively. Heparin was obtained from Serva (Heidelberg, Germany.). Cell culture trays were obtained from Costar (Cambridge, MA). Nonidet P40 (NP40) for fixation of cell monolayers was obtained from Sigma (St Louis, MO). Fibronectin was acquired from the central Laboratory of The Dutch Red Cross Transfusion Service (CLB), Amsterdam, The Netherlands. FITC-conjugated rabbit $\mathrm{F}(\mathrm{ab})_{2}$ anti mouse serum was obtained from DAKO (Amstelstad Zwanenburg, The Netherlands). Peroxidase-conjugated goat anti-mouse gammaglobulin was obtained from Jackson Immuno Research Laboratories (West Grove, PA). Glutaraldehyde for fixation of the cell monolayer and paraformaldehyde were obtained from Merck (Darmstadt, Germany). A polyclonal rabbit anti-natural human IL-1, which inhibits the biological activity of IL-1 was kindly provided by Dr. J. van Damme, Rega Institute of Medical Microbiology, University of Leuven, Belgium. Monoclonal antibody IB4, directed against the common beta chain (CD18) of LeuCAM, was a generous gift from Prof. M. Daha, University Hospital Leiden, The Netherlands. Monoclonal antibody ENA1, reactive with an inducible endothelial surface antigen with characteristics similar to those of ELAM-1 (24) was a generous gift from Dr. W.A. Buurman, University of Limburg, The Netherlands. This monoclonal reacts specifically with endothelial cells activated with tumor necrosis factor (TNF), IL-1, lipopolysaccharides (LPS) or phorbol esters and is not reactive with other cell types.

\subsubsection{Cells}

Human endothelial cell monolayers were established from cells, obtained by trypsin treatment of umbilical cord veins as described by Bruggeman et al. (26). The cells were grown in culture medium consisting of 50\% medium 199 (M199) and 50\% RPMI-1640 supplemented with heat-inactivated $20 \%$ foetal calf serum (FCS), heparin $(10 \mathrm{U} / \mathrm{ml}), 0.2 \%$ endothelial growth factor (EGF) (27) and antibiotics. The endothelial cell monolayers were used after five to eight doublings and were nearly confluent at the time of viral infection. The monolayers were grown in $90-\mathrm{mm}$ plastic petri dishes and for the adhesion assay in 96-well tissue culture cluster plates. For antigen detection studies the monolayers were grown also in 96-well tissue culture cluster plates containing $10^{4}$ cells/well.

Human embryonal fibroblasts (HEF) were cultured in Eagle's minimal essential medium (MEM) supplemented with heat-inactivated (at $56^{\circ} \mathrm{C}$ for $30 \mathrm{~min}$ ) $10 \%$ newborn calfserum (NCS) and antibiotics. Confluent HEF monolayers were used for the preparation of the viruspool.

Human polymorphonuclear leucocytes (PMN) were isolated from buffy coats, obtained after cytophoresis of blood of healthy donors, using the method described previously (10). 
The viability of isolated cells was determined by counting the percentage of cells that excluded trypan blue and was consistently found to be $>95 \%$. The purity of the harvested PMN was assessed by morphology as well as by chloro-acetate esterase staining (28) and $>90 \%$ of the cells were judged to be PMN. The isolated PMN were stored on ice in $\mathrm{Ca} / \mathrm{Mg}$-free Hanks' balanced salt solution (HBSS) supplemented with heat-inactivated $1 \%$ FCS. Before use in the adhesion assay experiments cells were resuspended in RPMI-1640 supplemented with $1 \%$ FCS.

\subsubsection{Viral techniques}

Cytomegalovirus (CMV) (Kerr strain) was grown in HEF monolayers and virus stocks with titers between 5 and $10 \times 10^{7} \mathrm{PFU} / \mathrm{ml}$ were prepared. The infectivity of the CMV pools was determined by plaque assay in HEF, as described for rat CMV (29).

Unless indicated otherwise, endothelial cell monolayers were infected with CMV at a multiplicity of infection (MOI) of 30 , using the technique described previously (10), and were used in the adhesion assay at 24 hours post-infection (p.i.). Virus antigen expression was determined, at different hours p.i., by means of an enzyme-linked immunosorbent assay (ELISA) or by an indirect immunofluorescence (IF) assay using CMV monoclonal antibodies (MoAb). The two MoAb H219 and H222, directed against CMV antigens, were prepared according to standard procedures (30). MoAb H222 gives a positive staining in the nucleus, while MoAb $\mathrm{H} 219$ is directed against cytoplasmic-CMV antigens. No crossreactivity with other herpes viruses could be detected.

For IF, virus-infected endothelial cell monolayers were fixed with $3 \%$ paraformaldehyde at room temperature for 10 minutes, then incubated with MoAb H222 (dilution 1/50) for 45 minutes at $37^{\circ}$, washed in phosphate-buffered saline and further incubated with FITC-conjugated rabbit anti-mouse gammaglobulin (dilution 1/25) during $30 \mathrm{~min}$. After washing, treated and nontreated endothelial cell monolayers were observed simultaneously in a Zeiss fluorescent microscope equipped with the appropriate barrier filters. Data were presented as percentage of cells which gave a positive staining/microscopic area.

For the detection of viral antigens in ELISA, endothelial cell monolayers were fixed with $3 \%$ paraformaldehyde supplemented with $0.1 \%$ triton $X-100$. After fixation the viral antigen expression was determined using MoAb $\mathrm{H} 219$ and goat anti-mouse peroxidase; Ophenylenediamine dihydrochloride (OPD) (Sigma) was used as substrate. The plates were read on a Microtitre ELISA reader at $492 \mathrm{~nm}$. The data were reported as the mean absorbance units from six- to eightfold determinations after subtraction of the background. The SD never exceeded $5 \%$ of the mean value. Control monolayers were incubated with medium harvested from uninfected monolayers and were processed in a similar manner.

\subsubsection{Induction and detection of an activation antigen ELAM-1 in CMV infected endothelial cell monolayers}

The expression of the ELAM-1 antigen was determined by ELISA in CMV-infected monolayers at different times p.i. In control experiments endothelial cell monolayers treated 
with IL-1 were used. For the detection of ELAM-1 by IF, monolayers were fixed with 3\% paraformaldehyde and observed in a Zeiss fluorescent microscope. The data are presented as percentage of cells which gave a positive staining/microscopic area.

\subsubsection{Detection of IL-1 activity in supernatants derived from CMV infected endothelial cells}

To detect whether infected endothelial cell monolayers excreted IL-1, supernatants from infected and noninfected endothelial cell monolayers were collected, at $24 \mathrm{hr}, 48 \mathrm{hr}$ and 72 $\mathrm{hr}$ p.i. Until used, these supernatants were stored at $-70^{\circ}$. IL- 1 activity was measured by using the bioassay based on sublines of D10G4.1 (D10) murine T-cell line, as described by Hopkins \& Humphreys (31).

\subsubsection{Inhibition of the ELAM-1 expression}

To inhibit the virus induced ELAM-1 expression, virus infected- and noninfectedmonolayers were incubated with anti-IL-1 during and after infection. At 12 hours p.i., the ELAM-1 expression was determined in ELISA. Controls consisted of infected and noninfected endothelial cell monolayers incubated without anti-IL-1. The data reported are mean values from eightfold determinations and the SD never exceeded $5 \%$ of the mean value.

\subsubsection{Adhesion assay}

Leucocyte adhesion to cultured endothelial cells was evaluated by a radiometric assay in which the PMN were labelled with ${ }^{51} \mathrm{Cr}\left(100 \mu \mathrm{Ci} / 10^{7}\right.$ cells, specific activity $5 \mathrm{mCi} / \mathrm{mg}$; Amersham, Amersham, Bucks, U.K.) for $45 \mathrm{~min}$ at $37^{\circ}$. The labelling reaction was stopped by the addition of cold buffer. Excess ${ }^{51} \mathrm{Cr}$ was removed by rinsing the labelled cells in excess buffer before addition to the monolayer. Endothelial cell monolayers were incubated with PMN for $15 \mathrm{~min}$ at $37^{\circ}$. After removing the supernatant, the monolayers were rinsed five times with medium RPMI-1640 supplemented with $20 \%$ FCS and successively lysed with $1.25 \%$ EDTA-trypsin. The cell fractions were counted on a gamma counter. The mean of eight replicate samples is presented and the data are expressed as percentage of attached cpm to total cpm.

To inhibit autocrine release of IL-1, anti-IL-1 was added to the cell monolayer during the experimental period. At $24 \mathrm{hr}$ p.i. the PMN adhesion was measured. Controls consisted of cell monolayers without anti-IL-1 incubation.

In order to block the activation antigen expressed on virus infected cell monolayers, endothelial cells were incubated for 30 min with $F(a b)_{2}$ fragments of MoAb ENA1 [ $F(a b)_{2}-$ MoAb ENA1] prior to adhesion evaluation. At $24 \mathrm{hr}$ p.i. the leucocyte adhesion was determined as described above. As controls, infected and non-infected monolayers without $\mathrm{F}(\mathrm{ab})_{2}$-MoAb ENA1 incubation were used. 
To evaluate whether the PMN adhesion to endothelial cell monolayers acts through the common beta chain (CD18) of LeuCAM, PMN suspensions were incubated with or without the monoclonal antibody against CD18 (MoAb-IB4) during $15 \mathrm{~min}$, before addition to the infected or non-infected monolayers.

\subsubsection{Statistical analysis}

To test the effect of virus infection on the PMN adhesion the Wilcoxon test was used. If the P-value was $\leq 0.05$, the difference between the values was determined as being significant.

\subsection{RESULTS}

\subsubsection{ELAM-1 and viral antigen expression}

Endothelial cells were examined by ELISA for the expression of the antigen, reactive with MoAb ENA 1, at 0, 3, 6, 12, 15, 20, 24, 28 and $44 \mathrm{hr}$ p.i. Viral antigen expression was measured in the same experiment. Fig. 1 shows the results of a representive experiment. The expression of the antigen reactive with MoAb ENAl is parallel to the viral antigen expression. Both were optimal after $12 \mathrm{hr}$; thereafter the expressions declined. At $20 \mathrm{hr}$ p.i. the expressions reached baseline values.

Control experiments, using Il-1, a known inducer of ELAM-1 (24), showed that the activation antigen expression was maximal after an incubation time of $6 \mathrm{hr}$; thereafter the expression declined (fig.2).

In additional experiments the ELAM-1 expression was determined by IF in virus- or IL-1-treated endothelial cell monolayers counting the number of MoAb ENA1-positive cells. A maximal antigen expression was detected at $12 \mathrm{hr}$ p.i. and after $6 \mathrm{hr}$ treatment with IL-1 (data not shown).
post infection (hr)
\% ENA1 antigen
$\%$ viral antigen

$\begin{array}{lll}6 & 30 & 10 \\ 12 & 60 & 20 \\ 24 & 25 & 20\end{array}$

table 1: Expression of viral antigen (MoAb H222) and activation antigen ELAM-1 (MOAb ENA1) on CMV infected endothelial cell monolayers is measured with IF at different $\mathrm{hr}$ post infection as described in viral techniques and data are presented as percentage of cells which gave a positive staining with MoAb ENA1 or with MoAb H222/microscopic area. 


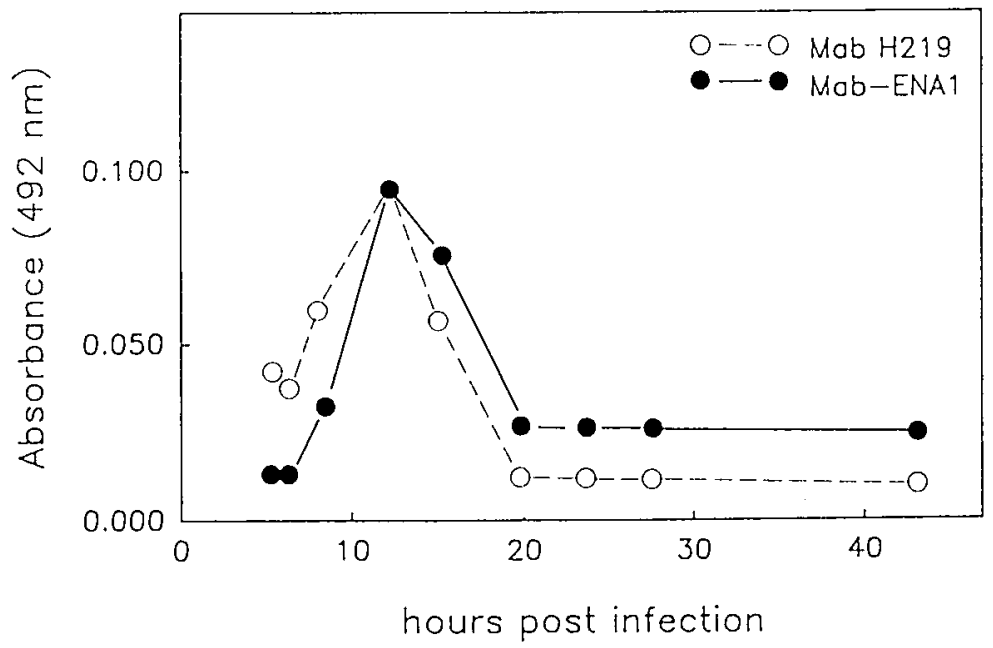

fig.1: Expression of virus antigen and activation antigen ELAM-1 on CMV infected endothelial cell monolayers at different hr post infection. The antigen expression was measured in ELISA and the values, expressed in absorbance units, are the mean of six-fold to eight-fold determinations as indicated in Materials and Methods section.

To assess whether the MoAb ENA1-positive cells were the CMV-infected endothelial cells, a double IF was performed. Infected and non-infected endothelial cell monolayers were incubated with a mixture of MoAb H222 (to detect viral antigens) and MoAb ENA1 (to detect ELAM-1) and examined at 6, 12 and $24 \mathrm{hr}$ p.i. (table 1). The infected endothelial cell monolayers expressed both MoAb ENA1 positive cells, giving a weak fluorescent signal on the cell surface membrane, and CMV-positive cells, giving a strong immunofluorescence in the nucleus. However, the endothelial cells which were MoAb ENA1 positive did not give a positive fluorescence with MoAb H222. Furthermore, it was not possible to discriminate CMV-plus ENA1-positive cells from only CMV-positive cells.

\subsubsection{Il-1 production and effect of anti-IL-1}

The production of IL- 1 after CMV infection was measured at 24,48 and $72 \mathrm{hr}$ p.i. No Il1 activity was measured in the supernatant during the experimental period. In a simultaneous experiment we studied, by incubating with anti-l1-1, if the expression of the antigen reactive with MoAb ENA1 was mediated by autocrine IL-1 release. After CMV 


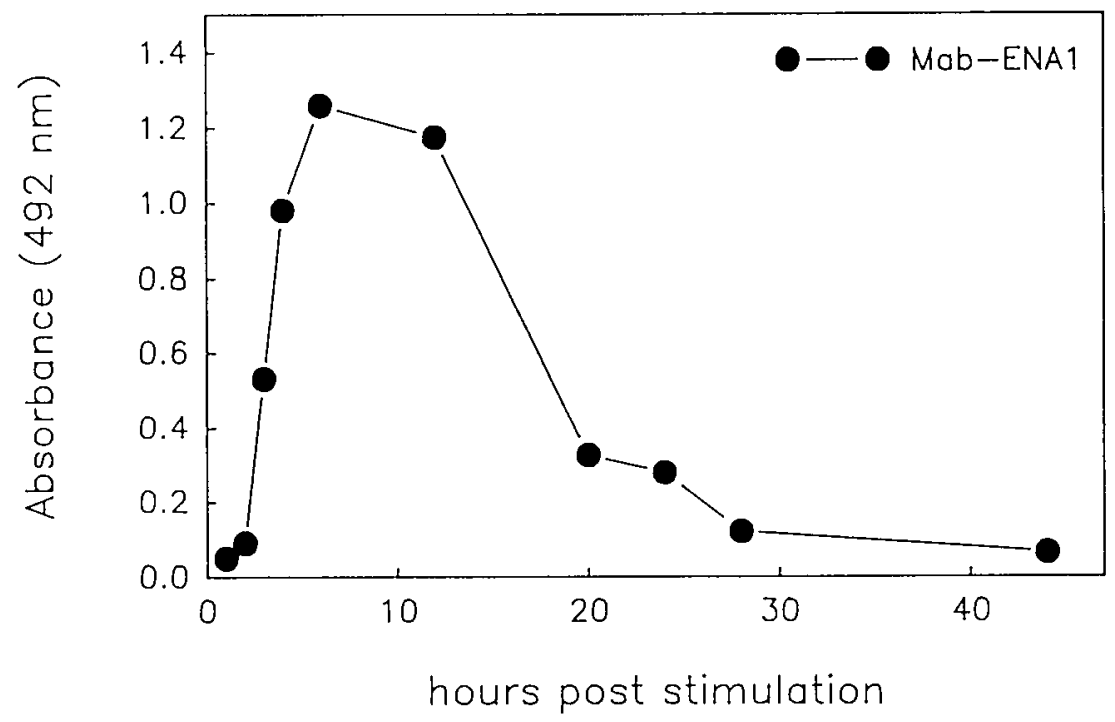

fig.2: Expression of activation antigen ELAM-1 on IL-1 treated endothelial cell monolayers after different hr of stimulation. The ELAM-1 expression was measured in ELISA, and the values are expressed in mean absorbance units from six-fold to eight-fold determinations; as indicated in Materials and Methods section.

infection an increased antigen expression, $160 \%$ of the control expression was detected in ELISA. Incubation with anti-IL-1 significantly reduced this increase of ELAM-1 expression by $75 \%$.

\subsubsection{Adhesion experiments}

Parallel to the antigen detection experiment the adhesion of ${ }^{51} \mathrm{Cr}$-labelled PMN to CMV infected and non-infected endothelial cells was measured. In addition, it was examined if the activation antigen ELAM-1 and Il-1 production were involved in the virus induced PMN adhesion by pretreatment of endothelial cells with anti-IL-1 or with $F(a b)_{2}$ fragments of MoAb ENA1.

Fig. 3 demonstrates that the PMN adhesion to CMV-infected endothelial cells was increased significantly up to $39 \%$. This increased adhesion was reduced with $64 \%$ by incubation with anti-Il-1. $\mathrm{F}(\mathrm{ab})_{2}$ fragments of MoAb ENAl reduced the PMN adhesion to CMVinfected endothelial cells by $80 \%, P<0.05$. Thus incubations with anti-IL- 1 or MoAb ENA1 reduced the virus-induced PMN adhesion to endothelial cell monolayers to almost control values. 


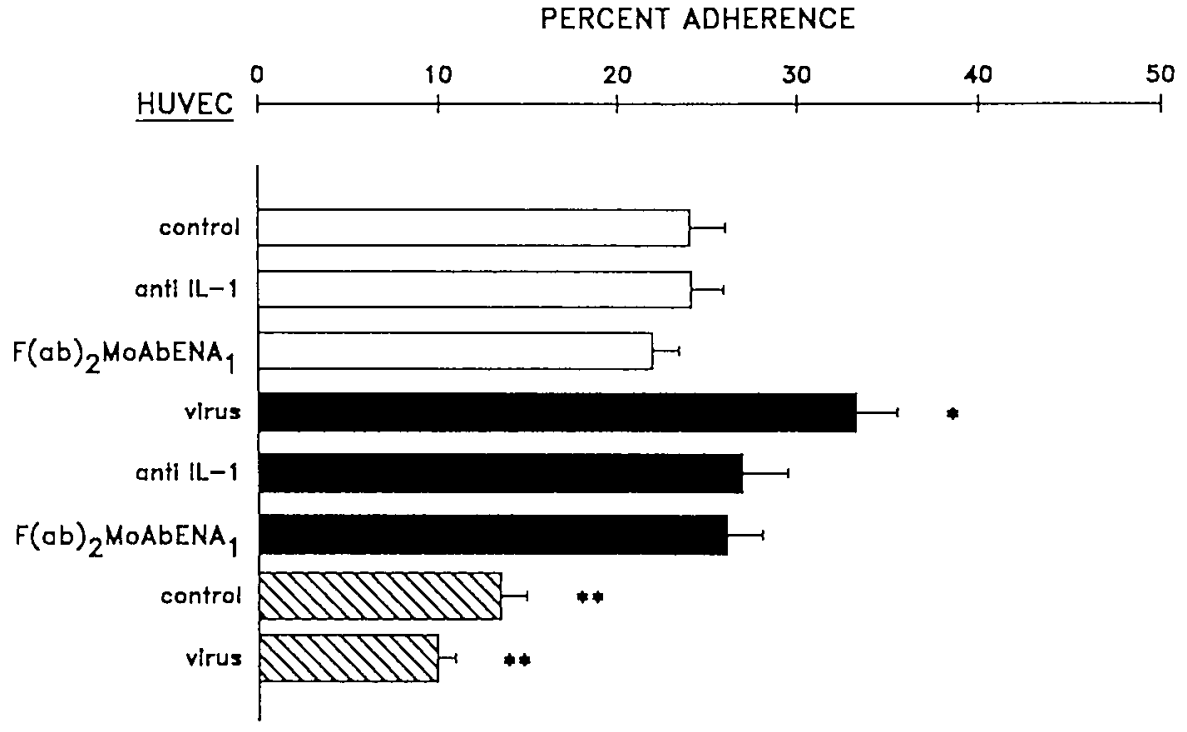

fig. 3: Effects of anti-IL-1 and F(ab) fragments of MoAb ENAl on control- and virus induced-adhesiveness. Endothelial cell monolayers were incubated, for 1 hour by $37^{\circ}$, in the presence of virus (closed bars) or supernatant derived from mock infected monolayers (open bars), washed 3 times and then exposed to anti-IL1 or $\mathrm{F}(\mathrm{ab})_{2}$-MoAb ENAl for $23 \mathrm{hr}$ at $37^{\circ}$. After washing two times, adhesion of untreated PMN or MoAbIB4 (against CD18) labelled PMN (hatched bars) was assessed using the ${ }^{51} \mathrm{Cr}$ method described in Material and Methods. Controls were compared with virus infected endothelial cells, or with MoAb-IB4 labelled PMN. (* P<0.05; ** P $<0.001)$.

\subsubsection{PMN adhesion through the CD18 receptor}

The relation of the virus induced adhesion with the CD18 antigen on the PMN was investigated. MoAb IB4 (directed against the common beta chain of LeuCAM [CD18]) was added to the PMN suspension before testing the adhesion. The results show that pretreatment of PMN with saturating concentrations of MoAb IB4 reduced the adhesion to non-infected and infected endothelial cell monolayers by $46 \%$ and $70 \%$, respectively (fig. $3)$. These values indicate that both control and virus-induced adhesion are mediated by CD18 and that virus infection results in an increased CD18 complex-dependent PMN adhesion. 


\subsection{DISCUSSION}

This study concerns the role of an activation antigen, reactive with MoAb ENA1, in the interaction of PMN with CMV-infected endothelium. CMV infection of endothelium results in the appearance of an activation antigen ELAM-1 which is recognized by MoAb ENA1. The expression of this antigen is maximal at $12 \mathrm{hr}$ p.i. The expression of the activation antigen was optimal after $6 \mathrm{hr}$ of incubation with IL-1. In both situations the ELAM-1 expression declined after maximal expression. Simultaneous to this activation antigen expression, the expression of viral antigens was measured. Since the two expression profiles show a similar time curve, a double IF was performed to test whether the observed CMV-induced activation antigen expression occurred in the virus-infected cells only. The results of these IF experiments indicate that in infected endothelial cell monolayers both ENA1- and CMV-positive cells do occur, but the cells reactive with MoAb ENA1 do not express the CMV antigens. On a cellular level it was not possible to detect both signals (i.e. ENA1 and CMV antigens) on the same cells. This does not exclude the fact that CMV-infected cells can express the activation antigen on the surface themselves, but is probably due to the limitation of the method. These results can be explained by the fact that CMV infection of the cells does not induce ELAM-1 expression directly but indirectly through one or more other factors resulting in the activation antigen ELAM-1 expression on non-infected cells.

Since IL-1 incubation induces the ELAM-1 expression (fig.2), the possibility exists that IL-1 is involved in our system. Although IL-1 production was not detected in the supernatant of infected monolayers, probably due to the fact that the amount of IL-1-producing cells was too low because only a maximum of $10 \%$ of the cells are infected (10), the role of IL-1 is supported by two observations. First, the PMN adhesion occurred on infected but also on non-infected endothelial cells. Second, the incubation with anti-IL-1 resulted in an almost complete decline of the virus-induced ELAM-1 expression. The adhesion experiments demonstrate that this antigen recognized by MoAb ENA1 is associated with the virus induced PMN adhesion. This is emphasized by the observation that the incubation with anti-IL-1 also reduced the virus induced PMN adherence. These results support the hypothesis that virus-induced PMN adhesion to endothelium is mediated by virus induced IL-1 production, which in turn activates the endothelial cells and causes the expression of an antigen recognized by MoAb ENA1. The inhibition of PMN adhesion, by $\mathrm{F}(\mathrm{ab})_{2}$ fragments of MoAb ENAI, indicates that the epitope reactive with MoAb ENA1 is involved in the CMV-induced PMN adhesion.

These findings are supported by other reports. Several investigators have shown that stimulation of endothelial cells results in the production of IL-1-like activities $(32,33)$. This locally produced IL-1 acts on target cells, including endothelial cells, and is able, at relative low concentration, to stimulate the endothelial plasma membrane by which neutrophils, monocytes (18) and lymphocytes (19) avidly adhere. In this interaction, caused by IL-1, different types of molecules expressed on the surface of endothelial cells are involved, such as ICAM-1, ICAM-2 and ELAM-1 (34-36). Recent studies in our laboratory have shown that the expression of ICAM-1 is also increased in CMV-infected endothelium (to be published). In addition it is demonstrated that the PMN adhesion is not reduced completely after incubation with $\mathrm{F}(\mathrm{ab})_{2}$ fragments of MoAb-ENA1. From this data it is evident that other antigens, as described above or the recently described GMP140 
protein, are involved. The GMP140 expression, present on platelets and endothelial cells, changes markedly after cellular activation (37). And as the domain organization of GMP140 is similar to that of ELAM1, a possible role in neutrophil binding is suggested (38) which was recently confirmed by Geng et al. (21).

Furthermore, the virus-induced IL-1 production is not the only mediator of the CMVinduced enhancement of PMN adhesion, as shown by the incomplete reduction of adhesion using anti-IL-1. This suggests again that other triggers may be involved in the induction of PMN adhesion, like viral proteins $(39,8)$, and platelet activating factor $(40,41)$.

Further, we studied if the PMN adhesion is mediated via the CD18 antigen present on the PMN membrane. The involvement of LFA-1, Mac-1, and p150,95 in the adhesion of leucocytes to endothelial cells has been established by inhibition experiments with MoAb anti-CD 18 (42). Our results suggest that adhesion of PMN to non-stimulated endothelial cells is dependent on the glycoprotein family (LeuCAM) expressed on the PMN membrane. Virus infection of endothelial cells up-regulates this CD18-dependent adhesion, which indicates that virus infection induces human endothelial cells to increase their adhesivity for PMN by a mechanism dependent on the common beta chain (CD18) of LeuCAM.

Finally, our observations document that virus infection modulates PMN adhesion to endothelial cells by changing the endothelial Il-1 secretion and the ELAM-1 expression (inhibitory effect on PMN adhesion of MoAb ENA1). Furthermore these results provide new insights into how CMV-altered endothelium becomes attractive to granulocytes. However, since the other mechanism(s) is unknown, much remains to be explored to extend our understanding of the complex interaction of leucocytes with the endothelial cells during virus infection.

\subsection{ACKNOWLEDGEMENTS}

This work was supported in part by grant no. 88-235 of the Dutch Heart Foundation. The authors thank Mrs. F. Claus-Hahn for the manuscript preparation, Prof. C van Boven for critical reading of the manuscript, the department of Obstetrics and Gynaecology and the Bloodbank of the University Hospital Maastricht, Maastricht, The Netherlands, respectively, for the supply of umbilical cords and buffycoats.

\subsection{REFERENCES}

1. Ross, R. (1986) The pathogenesis of atherosclerosis (An update). New Engl. J. Med. 314,488.

2. Fabricant, C.G., Fabricant, J., Litrenta, M.M. \& Minick, C.R. (1978) Virus induced atherosclerosis. J. Exp. Med. 148,335.

3. Gyorkey, F. Melnick, J.L., Guinn, G.A., Gyorkey, P. \& Debakey, M.E. (1984) Herpesviridae in the endothelial and smooth muscle cells of the proximal aorta in arteriosclerotic patients. Exp. Mol. Pathol. 40,328 .

4. Melnick, J.L., Dreesman, G.R., McCollum, C.H., Petrie, B.L., Burek, J. \& Debakey, M.E. (1983) Cytomegalovirus antigen within human arterial smooth muscle cells. Lancet ii,644. 
5. Hendrix, M.G.R., Dormans, P.H.J., Kitselaar, P., Bosman, F. \& Bruggeman, C.A. (1989) The presence of cytomegalovirus nucleic acids in arterial walls of atherosclerotic and non atherosclerotic patients. Am. J. Pathol. 134,1151.

6. Benditt, E.P., Barrett, T., \& McDougall, J.K. (1983) Viruses in the etiology of atherosclerosis. Proc. Natl. Acad. Sci. USA. 80,6386.

7. Visser, M.R., Jacob, H.S., Goodman, J.L., McCarthy, J.B., Furcht, L.T. \& Vercellotti, G.M. (1989) Granulocyte-mediated injury to herpes simplex virus-infected human endothelium. Lab. Invest. 60,296.

8. Zajac, B.A., O'Neill, K., Friedman, H.M. \& MacGregor, R.R. (1988) Increased adherence of human granulocytes to herpes simplex virus type 1 infected endothelial cells. In Vitro Cellular \& Developmental Biology 24,321.

9. MacGregor, R.R., Friedman, H.M., Macarak, E.J. \& Kefalides, N.A. (1980) Virus infection of endothelial cells increases granulocyte adherence. J. Clin. Invest. $65,1469$.

10. Span, A.H.M., van Boven, C.P.A. \& Bruggeman, C.A. (1989a) The effect of cytomegalovirus infection on the adherence of polymorphonuclear leukocytes to endothelial cells. Eur. J. Clin. Invest. 19,542.

11. Para, M.F., Baucke, R.B. \& Spear, P.E. (1982) Glycoprotein gE of herpes simplex virus type 1: effects of anti-gE on virion infectivity and on virus induced Fc-binding receptors. J. Virol. 41,129.

12. Friedman, H.M., Cohen, G.H., Eisenberg, R.J., Seidel, C.A. \& Cines, D.B. (1984) Glycoprotein C of herpes simplex virus type 1 acts as a receptor for the $\mathrm{C} 3 \mathrm{~b}$ complement component on infected cells. Nature (London) 309,633.

13. Dam-Mieras, M.C.E. van, Bruggeman, C.A., Muller, A.D., Debie \& W.H.M., Zwaal, R.F.A. (1987) Induction of endothelial cell procoagulant activity by cytomegalovirus infection. Thromb. Res. 47,69.

14. Pearson, J.P., Carleton, J.S., Beesley, J.E., Hutchings, A. \& Gordon, J.L. (1979) Granulocyte adhesion to endothelium in culture. J. Cell. Sci. 38, 225.

15. Whatley, R.E., Zimmerman, G.A., McIntyre, T.M., Taylor, R. \& Prescott, S.M. (1987) Production of platelet activating factor by endothelial cells. Seminars in Thrombosis and Hemostasis 13,445.

16. Häyry, P., Leszczynski, D., Paavonen, T., Nemlander, A., Meide, P. van de \& Schellekens, H. (1987) Leukocyte binding and la-expression in vascular endothelium. Transpl. Proc. 14,42.

17. Goerdt, S., Zwadlo, G., Schegel, R., Hagemeier, H.M., and \& Sorg, C. (1987) Characterization and expression kinetics of an endothelial cell activation antigen present in vivo only in acute inflammatory tissues. Exp. Cell. Biol. 55,117.

18. Bevilacqua, M.P., Pober, J.S., Wheeler, M.E., Cotran, R.S. \& Gimbrone, M.A. Jr. (1985) Interleukin 1 acts on cultured human vascular endothelium to increase the adhesion of polymorphonuclear leukocytes, monocytes, and related leukocyte cell lines. J. Clin. Invest. 76,2003.

19. Cavender, D.E., Haskard, D.O., Joseph, B. \& Ziff, M. (1986) Interleukin 1 increases the binding of human B and T lymphocytes to endothelial cell monolayers. J. Immunol, 136,203.

20. Dustin, M.L., Rothlein, R., Bhan, A.K., Dinarello, C.A. \& Springer, T.A. (1986) Induction by IL-1 and interferon, tissue distribution, biochemistry, and function of a natural adherence molecule (ICAM-1).

J. Immunol. 137,245 .

21. Geng, J.-G., Bevilacqua, M.P., Moore, K.L., McIntyre, T.M., Prescott, S.M., Kim, J.M., Bliss, G.A., Zimmerman, G.A. \& McEver, R.P. (1990) Rapid neutrophil adhesion to activated endothelium mediated by GMP-140. Nature 343,757 .

22. Bevilacqua, M.P., Pober, J.S., Wheeler, M.E., Cotran, R.S. \& Gimbrone, M.A. (1985) Interleukin-1 activation of vascular endothelium. Am. J. Pathol. 121,343.

23. Cotran, R.S., Gimbrone, M.A. Jr., Bevilacqua, M.P., Mendrick \& D.L., Pober, J.S. (1986) Induction and detection of a human endothelial activation antigen in vivo. J. Exp. Med. 164,661.

24. Leeuwenberg, J.F.M., Jeunhomme, G.H.A.A. \& Buurman, W.A. (1989) Induction of an activation antigen on human endothelial cells in vitro. Eur. J. Immunol. 19,715.

25. Leeuwenberg, J.F.M., Jeunhomme, G.M.A.A. \& Buurman, W.A. (1990) Adhesion of polymorphonuclear cells to human endothelial cells. Adhesion-molecule-dependent, and $\mathrm{Fc}_{\mathrm{c}}$ receptormediated adhesion-molecule-independent mechanisms. Clin. Exp. Immunol. (in press).

26. Bruggeman, C.A., Debie, W.H.M., Muller, A.D., Schutte, B. \& van Dam-Mieras, M.C.E. (1988) Cytomegalovirus alters the von Willebrand factor content in human endothelial cells. Thromb. Haemostasis 59,264 . 
27. Maciag, T., Cenundolo, I., Ilsley, S., Kelley, P.R. \& Foriand, R. (1979) An endothelial cell growth factor from bovine hypothalamus: Identification and partial characterization. Proc. Natl. Acad. Sci. USA 76,5674 .

28. Yam, L.T., Li, O.Y. \& Crosby, W.H. (1971) Cytochemical identification of monocytes and granulocytes. Am. J. Pathol. 5,283.

29. Bruggeman, C.A., Meyer, H., Dormans, P.H.J., Debie, W.H.M. \& Grauls, G.E.L.M. \& van Boven, C.P.A. (1982) Isolation of a cytomegalovirus-like agent from wild rats. Arch. Virol. 73,231.

30. Bruning, J.H., Debie, W.H.M., Dormans, P.H.J., Meijer, H. \& Bruggeman, C.A. (1987) The development and characterization of monoclonal antibodies against rat cytomegalovirus induced antigens. Arch. Virol. 94,55.

31. Hopkins, S.J. \& Humphreys, M. (1989) Simple, sensitive and specific bioassay of interleukin-1. J. Immunol. Methods 120,271.

32. Locksley, R.M., Heinzel, F.P., Shepard, H.M., Agosti, J., Eessalu, T.E., Aggarwal, B.B. \& Harlan, J.M. (1987) Tumor necrosis factors $\alpha$ and $B$ differ in their capacities to generate interleukin 1 release from human endothelial cells. J. Immunol. 139, 1891.

33. Schleimer, R.P. \& Rutledge, B.K. (1986) Cultured human vascular endothelial cells acquire adhesiveness for neutrophils after stimulation with interleukin 1, endotoxin, and tumor-promoting phorbol diesters. J. Immunol. 136,649.

34. Rothlein, R., Dustin, M.L., Marlin, S.D. \& Springer, T.A. (1986) A human intercellular adhesion molecule (ICAM-1) distinct from LFA-1. J. Immunol. 141,1665.

35. Bevilacqua, M.P., Pober, J.S., Mendrick, D.L., Cotran, R.S. \& Gimbrone, M.A. (1987) Identification of an indu-cible endothelial leukocyte adhesion molecule. Proc. Natl. Acad. Sci. USA. 84,9238.

36. Staunton, D.E., Dustin, M.L. \& Springer, T.A. (1989) Functional cloning of ICAM-2, a cell adhesion ligand for LFA-1 homologous to ICAM-1. Nature $339,61$.

37. McEver, R.P. \& Martin M.N. (1984) A monoclonal antibody to a membrane glycoprotein binds only to activated platelets. J. Biol. Chem. 259,9799.

38. Johnston, G.I., Cook, R.G. \& McEver, R.P. (1989) Cloning of GMP-140, a granule membrane protein of platelets and endothelium: sequence similarity to proteins involved in cell adhesion and inflammation. Cell 56,1033.

39. Ratcliffe, D.R., Nolin, S.L. \& Cramer, E.D. (1988) Neutrophil interaction with influenza-infected epithelial cells. Blood 72,142 .

40. Breviario, F., Bertocchi, F., Dejana, E. \& Bussolino, F. (1988) IL-1 induced adhesion of polymorphonuclear leukocytes to cultured human endothelial cells: Role of platelet-activating factor. J. Immunol. 141,3391.

41. Kimani, G., Tonnesen, M.G. \& Henson, P.M. (1988) Stimulation of eosinophil adherence to human vascular endothelial cells in vitro by platelet-activating factor. J. Immunol. 140,3161.

42. Harlan, J.M., Killen, P.D., Senecal, F.M., Schwartz, B.R., Yee, E.K., Tayer, R.F., Beatty, P.G., Price, T.H. \& Ochs, H.D. (1985) The role of neutrophil membrane glycoprotein gp-150 in neutrophil adherence to endothelium in vitro. Blood $66,167$. 
CHAPTER IX

SUMMARY AND CONCLUSIONS 



\subsection{INTRODUCTION}

This thesis describes the early virus induced vascular alterations observed in in vivo studies, and the early virus induced changes of endothelium in in vitro studies.

We compared the early virus induced alterations of the vessel wall in rats after a CMV infection with the early events induced by hypercholesterolemia in rats and compared our results with the findings made by others in this hypercholesterolemia model. The extra and intracellular changes induced by CMV infection and hypercholesterolemia were studied by means of light and electronmicroscopy. The findings are discussed in term of whether they support the hypothesis of virus involvement in the development of atherosclerosis. Since the earliest event associated with endothelial cell damage in vivo is an enhanced interaction of endothelial cells with leukocytes and platelets, the in vitro experiments were designed to study the possible effect of herpesvirus infection of endothelium on leukocyte and platelet interaction, and to investigate the possible mechanism(s) of this interaction.

\subsection{RELATION VIRUSINFECTION AND ATHEROSCLEROSIS IN VIVO?}

The effect of virus infection and hypercholesterolemia on the vessel wall in rats was quite similar. Both infection and hypercholesterolemia induced minimal endothelial cell damage, an increase in the number of adhering leukocytes onto the aortic intima, presence of lipophages and accumulation of lipids in the endothelium as shown by light microscopy (chapter III). The results of the ultrastructural studies show that the vascular lesions in $\mathrm{CMV}$ infected normocholesterolemic rats and noninfected hypercholesterolemic rats were highly similar and were characterized by minimal endothelial damage, lipid accumulation in the endothelial monolayer, extracellular lipid deposition in the subendothelium, and by the appearance of intimal foam cells and intimal T-lymphocytes. The vascular lesions described in the present study are also highly comparable to the early atherosclerotic lesions induced by hypercholesterolemia as described by others (1-7). The present results seem therefore to support the hypothesis that CMV-infection can act as a risk factor in the pathogenesis of atherosclerosis, and further substantiate the data obtained in humans indicating an association between herpesvirus and atherosclerosis (8-19).

The ultrastructural study showed, however, a striking difference between CMVinfected rats and hypercholesterolemic rats. CMV-infection induced an expansion of the subendothelial space not observed in hypercholesterolemic rats. The expanded space was filled with an increased amount of reticular basal lamina-like material, collagen fibrils and elastic fibers. This resulted in a loosening of the endothelial cells from the basement membrane. A similar virus effect was described by Visser et al. (20) in cultured endothelial cell monolayers infected by HSV-1. These findings do suggest that one of the possible pathophysiologic mechanisms by which virus infection contributes to the development of atherosclerosis is by loosening the attachment of endothelial cells to their basement membranes and making the cells more vulnerable to the detachment mediated by granulocytes. Consistent with this possibility are the observations that granulocytes were not only attracted to (21-24) and caused damage (25) to HSV-infected endothelium, but that HSV-infected endothelial cells were also more extensively detached from their matrix proteins by granulocyte-released proteinases than the noninfected cells (26). 


\subsection{IN VITRO STUDIES}

The initial lesion in the atherosclerotic process is generally considered to be an injury to the endothelial cells. The in vitro experiments show that both herpes viruses studied can absorb to and replicate in cultured endothelial cells (21-24,27,28 and chapter VI) causing cytopathological alterations. The immunofluorescence technique demonstrated, that HSV-1 resulted in almost $80-100 \%$ infection of the endothelial monolayer, while CMV only resulted in a $10 \%$ infection of the monolayer, even when a higher CMV-infection dose was used.

The in vivo studies indicate that another mechanism of early endothelial cell injury is mediated by an enhanced interaction of leukocytes with the endothelium. To gain more information about the virus induced adhesion, in vitro studies were performed. Monocyte, granulocyte and platelet interaction with infected endothelial cells were measured. The platelet interaction was investigated, since in advanced atherosclerotic lesions platelets were involved.

Infection of endothelial cells with HSV-1 (chapter VII) and with CMV (chapter VI, VII, VIII) resulted in a marked increase in adherence of granulocytes to endothelium. Similar results were obtained in adherence of monocytes (chapter V and VII), while no increase in platelet adhesion to virus infected endothelium was observed (chapter VII). This latter result is in accordance with other in vitro studies in wich also no increase in platelet adhesion to infected endothelium is observed (29).

For both viruses studied, increases in granulocyte- or monocyte- adherence developed early in course of infection, generally before extensive viral-induced changes in endothelial morphology were detected.

The augmentation of granulocyte and monocyte adherence to CMV or HSV-1 infected endothelium was almost reduced to control levels after tunicamycin treatment, while granulocyte and monocyte adherence to noninfected monolayers was not reduced. Respectively, Pizer et al.(30) and Norrild et al.(31) have demonstrated that tunicamycin interferes with the synthesis of HSV-specific glycoproteins or prevents the expression of viral glycoproteins on the surface of infected cells. By that our data suggests that viral and/or viral induced glycoproteins on the surface of the infected cell monolayers are responsible for the increased adherence. This statement is consistent with the result of Zajac et al.(24), who demonstrated also that viral glycoproteins were involved in the granulocyte adherence to HSV-1 infected endothelial cells. Her study presented, however, next to above mentioned adherence another type of virus induced adherence, which required the presence of antiviral antibodies (24), it was mediated by the Fc end of IgG. Earlier studies have shown that HSV-1 $(22,27,28)$ and CMV (32) infection induce receptors for the Fc portion of $\operatorname{IgG}$ (glycoprotein $\mathrm{E}$ [gE]) and for $\mathrm{C} 3 \mathrm{~b}$ (glycoprotein $\mathrm{C}$ $[\mathrm{gC}]$ ) on cultured endothelial cells. Presumably, the IgG-Fc fragments binds to the granulocyte- or to the endothelial-IgG-Fc receptor, and increase the granulocyte adhesion to virus infected cells. Etingin et al. (33) demonstrated that the HSV-1 induced monocyte adhesion, which was mediated by endothelial thrombin generation, required also surface expression of HSV-gC.

Nevertheless, $\mathrm{Fc}$ and $\mathrm{C} 3 \mathrm{~b}$ are not the only virus-induced surface antigens detectable on virus infected endothelial monolayers. As described in chapter VIII, two endothelial 
activation antigens were present after CMV infection of endothelial cells. An ELAM-1-like antigen and an increased ICAM-1 antigen expression were detected after CMV infection. It seems that the modulation of the virus induced ICAM-1 expression (detected by using the RR1/1 monoclonal antibody) differs from that of ELAM-1 (detected with monoclonal antibody ENA1). The ELAM-1 expression was found only on infected endothelial cell monolayers, while the ICAM-1 expression was measured on both noninfected and infected endothelial cell monolayers. The ENAl binding was maximal at 4 to $6 \mathrm{hr}$ post infection whereas RRl/l binding reached maximal levels at $24 \mathrm{hr}$ post infection (previously unpublished data). Finally, ENAl binding declines spontaneously (after 6hr), whereas RRl/I binding was sustained as long as we measured ( $48 \mathrm{hr}$ post infection) (previously unpublished data). This ELAM-1 antigen seems to be involved in the CMV induced granulocyte adherence. Incubation of the infected monolayer with $F(a b) 2$ fragments of monoclonal antibody ENAl reduced the granulocyte adherence to almost control level. Incubation of noninfected monolayers with this monoclonal antibody had no effect on the control adherence.

Chapter VIII shows that not only activated endothelial cells are responsible for the virus induced enhanced adherence, but probably also the granulocytes themselves are activated. Incubation of granulocytes with monoclonal antibody IB4, directed against the adhesion glycoprotein CD18 present on granulocytes, reduced the adhesion to noninfected and infected endothelial monolayers by $46 \%$ and $70 \%$, respectively. This result suggests that the adhesion to noninfected endothelial cells is CD18 glycoprotein dependent, and CMV infection up-regulates this glycoprotein-dependent mechanism.

We investigated if next to endothelial membrane antigens other factors such as soluble adherence promoting factors released after virus infection were involved in our in vitro model.

Supernatant studies described in chapter V,VI and VII show that the HSV-1 induced adherence of granulocytes and monocytes is probably related to the release of an adherence promoting factor(s): a significant increases in granulocyte and monocyte adherence were detected when endothelial monolayers were incubated with supernatant from HSV-1-infected cultures. A possible candidate for the HSV-1 induced adherence is prostacyclin. Visser et al.(29) reported that HSV-1 infection of endothelial cells resulted in a marked reduction of the prostacyclin synthesis. This in turn lessened the inhibition of granulocyte adherence and an enhanced granulocyte interaction $(23,34)$ to HSV-1 infected endothelial cells occured. Prostacyclin is probably not the only factor involved. Exposure of endothelial cells to virus induced the production of IFN $\alpha$ and IFN 3 (35), but also large amounts of IL-6 were produced after virus infection [e.g., Newcastle disease virus (NDV)] (36). In our model infection of endothelial cells or of fibroblasts with CMV resulted in IL6 production (previously unpublished data). IL- 6 is a pleiotrophic lymphokine that has colony stimulating factor activity (CSA). By producing CSA, endothelial cells participate in recruitment and activation of leukocytes (37).

Exposure of noninfected endothelial monolayers to supernatant fluids from CMV-infected cultures did not result in significant differences in granulocyte and monocyte adherence. The CMV induced increase of adherence is probably associated with the endothelial cell membrane: the virus induced adherence promoting factor remains associated. Another 


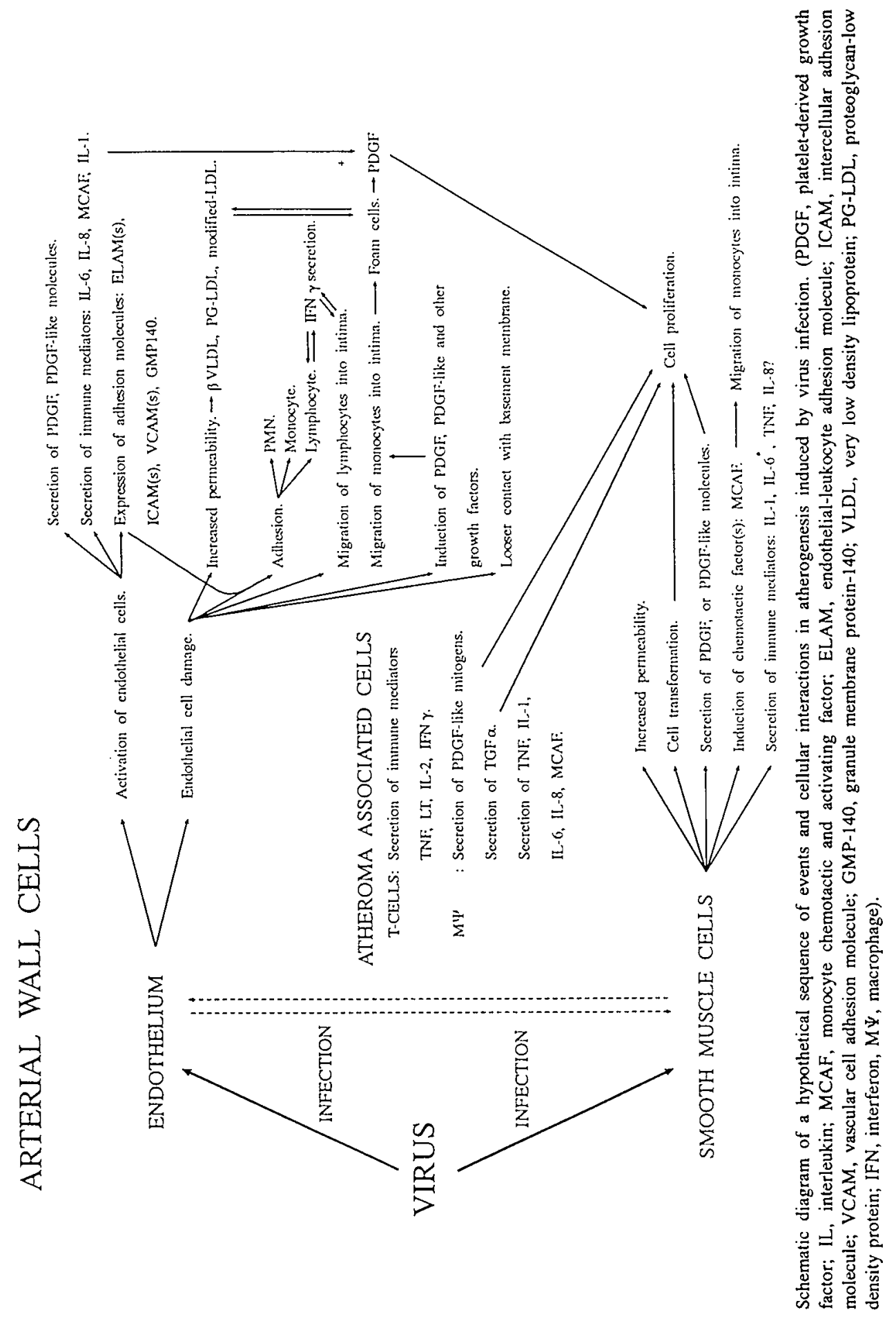


possibility can be that the soluble substance(s) released from the infected cultures acts on granulocytes and monocytes but not on endothelial cells. Incubation of CMV infected endothelial cells with anti-IL-1 (chapter VIII) showed that the CMV induced granulocyte adherence is partly reduced. However, endothelial-IL-1 production could not be measured in the supernatant derived from CMV infected endothelial cells. This observation supports the first proposed possibility and suggests that membrane associated IL-1 is involved in CMV-induced adherence. Other examples of endothelial cell-dependent adhesion mechanism are provided by platelet activating factor $(38,39)$ and thrombin. As mentioned above thrombin generation is involved in the HSV-induced monocyte adhesion (33). Thus, the localized activation of the coagulation cascade to the exposed vascular surface is probably involved in pathogenesis of virus-induced vascular injury.

\subsection{CONCLUSION AND HYPOTHESIS}

In conclusion, similarly enhanced interactions between membrane structures on endothelial cells, and on monocytes and granulocytes, as found in vitro, are likely to be responsible for the enhanced leukocyte adherences and for the virus-induced endothelial cell damage observed in the early stages of virus induced atherosclerosis in vivo (chapter III and IV).

In vitro experiments as well as the study of the arteries from infected animals suggest that a virus-induced alteration of endothelial cells, which results in the enhanced adhesion of monocytes and granulocytes, minimal endothelial cell damage, and in accumulation of cholesterol and cholesteryl esters, can be the primary mechanisms in the development of viral induced atherosclerosis (see diagram).

From the results described in this thesis the following working hypothesis of the steps involved in the virus-induced atherosclerosis is postulated.

After an systemic herpes virus infection the endothelium of vessel walls becomes locally infected. This local infection induces activation of the endothelial cells which in turn induces an inflammatory response: adhesion of monocytes, lymphocytes and granulocytes, and it can induce alterations in matrix protein synthesis (20). These changes in turn can lead to a minimal damage of endothelial cells. The virus can replicate in some endothelial cells and infect the neighbouring smooth muscle cells within the arterial wall resulting in latent or persistent infections of these cells. CMV infection of endothelial cells or of smooth muscle cells by systemic infection or by reactivation the smooth muscle cells, may induce changes in the cellular metabolism of these cells, including cholesterol accumulation $(42,43)$, and production of growth- or chemotactic-factors $(36)$, which cause proliferation and migration of the smooth muscle cells. This last event is seen as a key event in the development of an atherosclerotic plaque.

\subsection{REFERENCES}

1. Lewis JC, Taylor RG, Jones ND, St Clair RW, Cornhill JF: Endothelial surface characteristics in pigeon coronary artery atherosclerosis. I. Cellular alterations during the initial stages of dietary cholesterol challenge. Lab Invest 46: 123, 1982. 
2. Joris I, Zand T, Nunnari JJ, Krolikowski FJ, Majno G: Studies on the pathogenesis of atherosclerosis I. Adhesion and emigration of mononuclear cells in the aorta of hypercholesterolemic rats. Am J Pathol I 13: $341,1983$.

3. Jerome WG, Lewis JC: Early atherogenesis in white carneau pigeons. I. Leukocyte margination and endothelial alterations at the celiac bifurcation. Am J Pathol 116: 56, 1984.

4. Faggiotto A, Ross R: Studies of hypercholesterolemia in the nonhuman primate. I. Changes that lead to fatty streak formation. Arteriosclerosis 4: 323, 1984.

5. Faggiotto A, Ross R: Studies of hypercholesterolemia in nonhuman primate. II. Fatty streak conversion to fibrous plaque. Arteriosclerosis 4: 341, 1984.

6. Gabaldon $M$, Capdevila $C$ : Adhesion of leukocytes to the aortic endothelium of conventional, specific pathogen free (SPF) and hypercholesterolemic SPF rats. Atherosclerosis 75: 83, 1989.

7. Nakamura $\mathrm{H}$, Izumiyama $\mathrm{N}$, Nakamura $\mathrm{K}$, Ohtsubo $\mathrm{K}$ : Age-associated ultrastructural changes in the aortic intima of rats with diet-induced hypercholesterolemia. Atherosclerosis 79: 101, 1989.

8. Melnick JL, Petrie BL, Dreesman GR, McCollum CH, Burek J, DeBakey ME: Cytomegalovirus antigen within human arterial smooth muscle cells. Lancet 2: 644, 1983.

9. Benditt EP, Barrett T, McDougall JK: Viruses in the etiology of atherosclerosis. Proc Natl Acad Sci USA 80: $6386,1983$.

10. Gyorkey F, Melnick JL, Guinn GA, Gyorkey P, DeBakey ME: Herpesviridae in the endothelial and smooth muscle cells of the proximal aorta in arteriosclerotic patients. Exp Mol Pathol 40: 328, 1984.

11. Petrie BL, Melnick JL, Adam E, Burek J, McCollum CH, DeBakey ME: Nucleic acid sequences of cytomegalovirus in cells cultured from human arterial tissue. J Infect Dis 155: 158, 1987.

12. Adam E, Probtsfield JL, Burek J, McCollum CH, Melnick JL, Petrie BL, Dailey KR, DeBackey ME: High levels of cytomegalovirus antibody in patient requiring vascular surgery for atherosclerosis. Lancet 8554: 291, 1987.

13. Yamashiroya HM, Ghosh L, Yang R, Robertson AL Jr: Herpesviridae in the coronary arteries and aorta of young trauma victims. Am J Pathol 130: 71, 1988.

14. Hendrix MGR, Dormans PHJ, Kitslaar P, Bosman F, Bruggeman CA: The presence of cytomegalovirus nucleic acids in arterial walls of atherosclerotic and nonatherosclerotic patients. Am J Pathol 134: 1151, 1989.

15. Hendrix MGR, Salimans MMM, van Boven CPA, Bruggeman CA: High prevalence of latently present cytomegalovirus in arterial walls of patients suffering from grade III atherosclerosis. Am J Pathol 136: 23, 1990.

16. Wreghitt TG, Hakim M, Gray JJ, Kucia S, Cory-Pearce R, Wallwork J, English TAH: A detailed study of cytomegalovirus infections in the first 160 heart and heart/lung transplant recipients at Papworth Hospital, Cambridge, England. Transplant Proc 19: 2495, 1987.

17. Grattan MT, Moreno-Cabral CE, Stames VA, Oyer PE, Stinson EB, Shumway NE: Cytomagalovirus infection is associated with cardiac allograft rejection and atherosclerosis. JAMA 261: 3561, 1989.

18. McDonald K, Rector TS, Braunlin EA, Kubo SH, Olivari MT: Association of coronary artery disease in cardiac transplant recipients with cytomegalovirus infection. Am J Pathol 64: 359, 1989.

19. Hruban RH, Wu T-C, Beschomer WE, Cameron DE, Ambinder RF, Baumgartner WA, Reitz BA, Hutchins GM: Cytomegalovirus nucleic acids in allografted hearts. Human pathol 21: 981, 1990

20. Visser MR, Vercellotti GM, McCarthy JB, Goodman JL, Herbst TJ, Furcht LT, Jacob HS: Herpes simplex virus inhibits endothelial cell attachment and migration to extracellular matrix proteins. Am $J$ Pathol 134: 223, 1989

21. Friedman HM, Macarak EJ, MacGregor RR, Wolfe J, Kefalides NA: Virus infection of endothelial cells. J Infect Dis 143: 266, 1981.

22. Friedman HM, Cohen GH, Eisenberg RJ, Seidel CA, Cines DB: Glycoprotein C of herpes simplex virus acts as a receptor for the C3b complement component on infected cells. Nature 309: 633, 1984.

23. MacGregor RR, Friedman HM, Macarek EJ, Kefalides NA: Virus infection of endothelial cells increases granulocyte adherence. J Clin Invest 65: 1469, 1980.

24. Zajac BA, O'Neill K, Friedman HM, MacGregor RR: Increased adherence of human granulocytes to herpes simplex virus type 1 infected endothelial cells. In vitro Cell Devel Biol 24: 321, 1988. 
25. Visser MR, Vercellotti GM, Goodman JL, Jacob HS: Granulocytes injure herpes simplex virus type Iinfected endothelial cells: implications for atherogenesis. Clin Res 34: 959A, 1986

26. Visser MR, Vercellotti GM, Goodman JL, Mc Carthy JB, Furcht LT, Jacob HS: Herpes simplex virus infection promotes granulocyte-mediated endothelial cell detachment by altering extracellular matrix proteins, cytoskeleton and membrane phospholipids. Clin Res 35: 434A, 1987.

27. Cines DB, Lyss AP, Bina M, Corkey R, Kefalides NA, Friedman HM: FC and C3 receptors induced by herpes simplex virus on cultured human endothelial cells. J Clin Invest 69: 123, 1982.

28. Para MF, Baucke RB, Spear PG: Glycoprotein E of herpes simplex virus type 1: Effects of anti-gE on virion infectivity and on virus induced Fc-binding receptors. J Virol 41: 129, 1982.

29. Visser MR, Tracy PB, Vercellotti GM, Goodman JL, White JG, Jacob HS: Enhanced thrombin generation and platelet binding on herpes simplex virus-infected endothelium. Proc Natl Acad Sci USA 85: $8227,1988$.

30. Pizer LI, Cohen GH, Eisenberg RJ: Effect of tunicamycin on herpes-simplex virus glycoproteins and infectious virus production. J Virol 34: 142, 1980

31. Norrild B, Pederson B: Effect of tunicamycin on the synthesis of herpes-simplex virus type 1 glycoproteins andtheir expression on the cell surface. J Virol 43: 395, 1982

32. Ryan US, Schultz DR, Ryan JW: $F c$ and $C 3 b$ receptors on pulmonary endothelial cells: induction by injury. Science 214: 557, 1981.

33. Etingin OR, Silverstein RL, Friedman HM, Hajjar DP: Viral activation of the coagulation cascade: Molecular interactions at the surface of infected endothelial cells. Cell 61: 657, 1990.

34. Visser MR, Jacob HS, Goodman JL, McCarthy JB, Furcht LT, Vercellotti GM: Granulocyte-mediated injury to herpes simplex virus-infected human endothelium. Lab Invest 60: 296, 1989.

35. Einhorn S, Eldor A, Vlodavsky I, Fuks ZVI, Panet A: Production and characterization of interferon from endothelial cells. J Cell Physiol 122: 200, 1985.

36. Van Damme, Schaafsma MR, Fibbe WE, Falkenburg JHF, Opdenakker G, Billiau A: Simultaneous production of interleukin 6 , interferon- $\beta$ and colony-stimulating avtivity by fibroblast after viral and bacterial infection. Eur J Immunol 19: 163, 1989.

37. Mantovani A, Dejana E: Cytokines as communication signals between leukocytes and endothelial cells. Immunol Today 10: 370, 1989.

38. Hwang SB: Identification of a second putative receptor of platelet-activating factor from human polymorphonuclear leukocytes. J Biol Chem 263: 3225, 1988.

39. Zimmerman GA, McIntyre TM, Mehra M, Prescott SM: Endothelial cell-associated platelet-activating factor: A novel mechanism for signaling intercellular adhesion. J Cell Biol 110: 529, 1990.

40. Gönczöl E, Boldogh I, Vaczi L: IgG-Fc-binding receptors in cells abortively infected, or transformed, by human cytomegalovirus. Acta Microbiol Acad Sci Hung 28: 157, 1981.

41. Smiley ML, Mar E-C, Huang E-S: Cytomegalovirus infection and viral-induced transformation of human endothelial cells. J Med Virol 25: 213, 1988.

42. Fabricant CG, Hajjar DP, Minick CR: Lipid accumulations in cultured vascular smooth muscle cells infected with Marek's disease herpesvirus. Fed Proc 39: 1110, 1980.

43. Hajjar DP, Fabricant CG, Minick CR, Fabricant J: Virus-induced atherosclerosis - herpesvirus infection alters aortic cholesterol metabolism and accumulation. Am J Pathol 122: 62, 1986. 


\section{SAMENVATTING}

Vele cardiovasculaire ziekten vinden hun oorzaak in atherosclerosis. Een groot aantal complexe interacties zijn betrokken bij het onstaan van atherosclerose. Aan de ene zijde spelen cellulaire en humorale bloed componenten een rol, aan de andere zijde zijn daarbij bestanddelen van de vaatwand betrokken. In het algemeen wordt "endotheel beschadiging" gezien als de eerste fase in het ontstaan van een atherosclerotische lesie. Echter noch de primaire oorzaken noch de volgorde van de gebeurtenissen die resulteren in een atherosclerotische vaatwand beschadiging zijn volledig bekend. Een van de hypothesen is dat virale infecties van de vaatwand door beschadiging van het endotheel het atherosclerotische proces kunnen initieren.

In deze dissertatie worden een aantal aspecten van "endotheel beschadiging" door herpesvirussen bestudeerd.

Hoofdstuk I beschrijft de mogelijke relatie tussen virale infectie en atherosclerose. De doelstellingen van de dissertatie en de hoofdlijnen van de studie worden geschetst.

In hoofdstuk II wordt aan de hand van de literatuur een overzicht gegeven van de pathogenese van atherosclerose door virale infectie. Endotheel beschading in vivo en in vitro, en endotheel-leukocyt interacties zijn in detail beschreven.

In hoofdstuk III en IV wordt de ontwikkeling van een in vivo model beschreven voor het onderzoek naar de hypothese betreffende de relatie tussen virus en de ontwikkeling van atherosclerose. Ratten gevoed met een hoog-cholesterol dieet zijn gebruikt als controle groep in deze studie. Licht-microscopish onderzoek toont een toename in leukocyt adhesie aan het endotheel van de vaatwand, migratie van leukocyten naar het subendothelium, en vet ophoping in het endotheel in ratten geïnfecteerd met het cytomegalovirus (CMV) aan. Ratten gevoed met een hoog cholesterol dieet, waarvan het bekend is dat het atherosclerose kan induceren, vertonen soortgelijke veranderingen. De ultrastructurele studie beschreven in hoofdstuk IV toont eveneens boven beschreven morfologische veranderingen aan. Echter naast de boven genoemde veranderingen worden: een toename in lipiden in het subendothelium, de aanwezigheid van lymphocyten en van "foam" cellen in het subendothelium, en een losser contact van endotheel cellen met de basale membraan waargenomen. Dit laatste phenomeen wordt alleen gezien in CMV-geïnfecteerde ratten. Het suggereert dat de rol van CMV in atherogenese onder andere plaats heeft door middel van de volgende stappen: virus infectie van de vaatwand veroorzaakt een lossere binding tussen het endotheel en de basale membraan. Ook wordt een toename in leukocyt-adhesie geinitieerd door virus infectie. Deze adherente cellen, waaronder granulocyten, kunnen het losser gebonden endotheel makkelijker beschadigen en dit kan uiteindelijk resulteren in een vaatwand beschadiging.

Gezien het feit dat in vivo adhesie van leukocyten aan endotheel cellen optreedt na virus infectie wordt in vitro deze adhesie nader onderzocht. Monocyt, granulocyt, en thrombocyt adhesies zijn bestudeerd na herpesvirus infectie, metname herpes simplex virus (HSV-1) en CMV zijn in deze studies gebruikt. De in vitro experimenten tonen aan dat beide virus infecties resulteren in een toename in monocyt- en granulocyt-adhesie aan endotheel cellen (hoofdstuk V,VI,VII,VIII). De toename in beide adhesies vindt plaats wanneer er nog geen cytopathologie waarneembaar is en wanneer slechts een percentage van de endotheel cellen is geïnfecteerd (hoofdstuk V, VI). De thrombocyt adhesie neemt echter niet toe na virus 
infectie (hoofdstuk VII). De monocyten en granulocyten reageren echter verschillend met het virus-geïnfecteerd endotheel. Meer granulocyten dan monocyten binden aan het geïnfecteerd endotheel (hoofdstuk VII). Maar ook een verschil in virus effect wordt waargenomen. De toename in monocyt en granulocyt adhesie aan HSV-1 geinfecteerd endotheel wordt gemeten wanneer niet-geïnfecteerde cellen geïncubeerd worden met het medium afkomstig van HSV-1-geïnfecteerde cellen (hoofdstuk V, VII), hetgeen suggereert dat oplosbare factoren verantwoordelijk zijn voor de toename in het adhesie. Echter, de adhesie gemeten na CMV infectie wordt niet geïnduceerd door oplosbare factoren aanwezig in het medium van geïnfecteerde cellen (hoofdstuk VI, VII). Het laatste resultaat suggereert dat de monocyt- en granulocyt-adhesie aan HSV-1 geïnfecteerd endotheel wordt veroorzaakt door secretie van een adhesie-stimulerende factor(en), terwijl de adhesie van monocyten en granulocyten aan CMV-geïnfecteerd endotheel waarschijnlijk een celgebonden phenomeen is.

De toename in monocyt en granulocyt-adhesie geïnduceerd door beide herpes virussen wordt geremd door tunicamycine behandeling (hoofdstuk V, VI, VII), hetgeen suggereert dat zowel de monocyt als de granulocyt-adhesie tot stand komt door de expressie van glycoproteinen op de endotheel membraan na virus infectie.

Een mogelijk mechanisme van een verhoogde granulocyt-adhesie na CMV infectie is beschreven in hoofdstuk VIII. Op endotheel cellen geïnfecteerd met CMV komt een activatie-antigeen tot expressie. Dit activatie-antigeen wordt herkend door de monoclonale antistof (moab) ENA1. Moab ENA1 reageert met een membraan gebonden endotheelantigeen dat overeenkomstige eigenschappen heeft met ELAM-1, waarvan bekend is dat het is betrokken bij granulocyt-adhesie. Incubatie met het anti-interleukine-1 (anti-IL-1) remt de expressie van het ELAM-1 achtig molecuul, en remt de virus-geïnduceerde granulocyt-adhesie. De adhesie van granulocyten kan ook geremd worden na incubatie van granulocyten met het moab IB4 (gericht tegen CD18, aanwezig op de membraan van granulocyten). De resultaten verkregen na CD18 incubatie suggereren dat de granulocytadhesie aan niet geïnfecteerd endotheel afhankelijk is van het CD18 glycoprotein en virus infectie resulteert in een opwaardering van dit $\mathrm{CD} 18$-afhankelijk mechanisme. Bovengenoemde resultaten duiden erop dat de virus-geïnduceerde granulocyt-adhesie wordt gereguleerd door het volgend mechanisme: Virus infectie van het endotheel resulteert in de productie van IL-1 en deze autocrine IL-1 productie veroorzaakt de expressie van het ELAM-1 molecuul, dat op haar beurt bindt met het putatieve ligand aanwezig op de granulocyt membraan. Daarnaast vindt de virus-geïnduceerde granulocyt-adhesie ook door een CD18 glycoprotein-afhankelijk mechanisme plaats.

In hoofdstuk IX worden de experimentele resultaten belicht tegen een bredere achtergrond. Hieruit blijkt dat virus infectie waarschijnlijk meerdere mechanismen op gang brengt die kunnen leiden tot vaatwand beschadiging. 



\section{DANKWOORD}

Het onderzoek beschreven in dit proefschrift werd financieel ondersteund door de Nederlandse Hartstichting (project nr.88-235).

Deze dissertatie is tot stand gekomen dankzij de aandacht, ondersteuning, medewerking en practische vaardigheden van de volgende personen.

Op de eerste plaats ben ik mijn copromotor Dr. CA Bruggeman zeer erkentelijk. Beste Catrien, ik bedank je voor je naaste begeleiding, en voor je goede en waardevolle suggesties en nieuwe ideeën die je me hebt toe gespeeld wanneer je je even vrij hebt kunnen maken van je andere beslommeringen. Deze raadgevingen en je stimulerende houding resulteerde uiteindelijk in deze dissertatie. Maar ook je kritische kijk tijdens het schrijven van deze dissertatie heeft haar steentje bijgedragen.

Prof.dr. CPA van Boven, beste Cees, bedankt voor jouw begeleiding en goede en stimulerende suggesties, vooral in deze laatste fase. Zonder dat had deze dissertatie niet de huidige vorm bereikt.

Wil Mullers, beste Wil, ik bedank je voor de fijne samenwerking en de kritische suggesties die jij tijdens onze besprekingen naar voren bracht en voor de figuren die jij elke keer weer met veel zorg uit de computer wist te draaien.

Jorike Endert, Gert Grauls, Wiel deBie, Peter Dormans ben ik dankbaar voor hun adequate technische assistentie en/of suggesties.

Dr. PM Frederik, beste Peter, ik bedank je voor de bijgedrage van een vruchtbare samenwerking tussen de vakgroep "virologie" en de afdeling "electronen microscopie".

Marc Stuart en Paul Bomans ben ik dankbaar voor het menig uurtje dat zij vrij maakten om het werken met de electronen microscoop mogelijk te maken.

Hans van Dijck ben ik dankbaar voor het vele geduld dat hij heeft opgebracht tijdens het ontwikkelen van al het foto materiaal.

De leden van de beoordelingscommissie; Prof.dr. FCS. Ramaekers, Prof.dr. FT. Bosman, Prof.dr. J. Drukker, Prof.dr. R. Furth, en Prof.dr. RFA. Zwaal wil ik bedanken voor de kritische evaluatie van het manuscript.

Tevens wil ik allen, die niet met name vermeld zijn, maar wel een bijdrage aan deze dissertatie geleverd hebben, van harte bedanken.

Tenslotte, lieve pap en mam, Misha heeft veel van jullie tijd gebruikt waardoor mij menig uurtje gegeven werd om rustig te werken. Mijn dank aan jullie is moeilijk weer te geven.

Dear Jason, I used a lot of the time we could have spent together for making my thesis book possible. Without your patience, understanding, care and love, it was never possible for me to finish this job. Thank you for all. 
' 


\section{CURRICULUM VITAE}

De auteur werd geboren op 3 november 1959 in Geleen. In 1979, na het behalen van het eindexamen Atheneum B aan het Albert Schweitzer Scholengemeenschap te Geleen, begon zij aan haar studie biologie aan de Katholieke Universiteit te Nijmegen. Op 1 juni 1983 werd het candidaatsexamen biologie behaald. Het doctoraalexamen met als bijvakken Submicroscopische Morfologie van de plant en Experimentele Dermatologie en het hoofdvak Algemene Microbiologie werd op 25 juni 1985 behaald. In de periode van augustus 1985 tot augustus 1986 verrichtte zij onderzoek bij de vakgroep Dermatologie aan de Katholieke Universiteit te Nijmegen. In de periode van september 1986 tot januari 1987 was zij werkzaam als tijdelijk onderzoeksmedewerker aan de faculteit Diergeneeskunde te Utrecht. Op 14 januari 1987 werd een begin gemaakt met een promotieonderzoek bij de vakgroep Medische microbiologie aan de Rijksuniversiteit Limburg te Maastricht, getiteld:

"Association between herpes virus infection and arterial diseases". 